Georgetown University Law Center

Scholarship @ GEORGETOWN LAW

2014

\title{
Constitutional Skepticism: A Recovery and Preliminary Evaluation
}

Louis Michael Seidman

Georgetown University Law Center, seidman@law.georgetown.edu

This paper can be downloaded free of charge from:

https://scholarship.law.georgetown.edu/facpub/1312

http://ssrn.com/abstract=2387031

This open-access article is brought to you by the Georgetown Law Library. Posted with permission of the author. Follow this and additional works at: https://scholarship.law.georgetown.edu/facpub

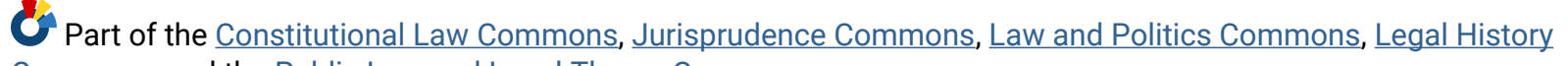
Commons, and the Public Law and Legal Theory Commons 
Constitutional Skepticism:

A Recovery and Preliminary Evaluation

Louis Michael Seidman ${ }^{*}$

\footnotetext{
$*$

Carmack Waterhouse Professor of Constitutional Law, Georgetown University Law Center.

I owe a special debt of gratitude to Michael Klarman, who gave me many, many single spaced pages of comments on an earlier draft of this article. I also received very helpful comments from Adam Cox, Michael Diamond, Peter Edelman, Daniel Ernst, Aziz Huq, Vicki Jackson, Jerry Kang, Daryl Levinson, Deborah Malamud, Allegra McLeod, Adam Samaha Girardeau Spann, Mark Tushnet, Laura Weinrib and participants at the Georgetown Faculty Workshop and the Duke Roundtable on the Role of Custom, Convention, and Tradition in U.S.

Constitutional Law. I am grateful to Noah Baron, Melissa Stewart, Morgan Stoddard, Katie Wrede, and the staff of the Georgetown Law Center Library for superb research assistance.
} 


\section{Constitutional Skepticism:}

\section{A Recovery and Preliminary Evaluation}

\section{Introduction}

Over two centuries after its ratification, most Americans are still infatuated with their

Constitution. ${ }^{1}$ At the beginning, few would have predicted this outcome. The Constitution was born

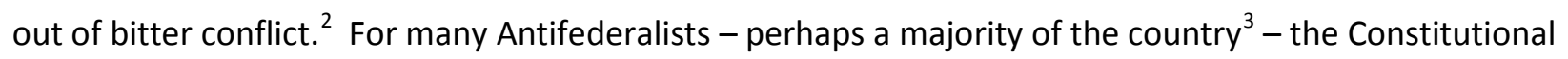

Convention amounted to a counterrevolution, a renunciation of everything that the War for

Independence had been fought to secure. ${ }^{4}$ The ratification process was arguably illegal ${ }^{5}$ and

1 See, e.g., "The AP- National Constitution Center Poll, August, 2012,

http://constitutioncenter.org/media/files/data GfK AP-

NCC Poll August GfK 2012 Topline FINAL 1st release.pdf (almost seven in ten Americans agree that "[t]he United States Constitution is an enduring document that remains relevant today.")

2 See generally Pauline Maier, Ratification: The PeOple Debate the Constitution, 1787-1788 (2010); WoOdy Holton, UnRuly Americans AND the Origins of the Constitution (2007); .Bruce Ackerman \& Neil Katyal, Our Unconventional Founding, 62 U. CHI. L. REV 475 (1995).

3 For a claim that "something like half the citizenry opposed [ratification]," see WOODY HOLTON, UNRULY AMERICANS AND THE ORIGINS OF THE CONSTITUTION 249 \& n. 56 (2007). There is no way to know the views of the many women, people of color, and people lacking property, who could not participate in elections for the state conventions. At a number of ratifying conventions, delegate selection districts were gerrymandered so as to overstate the power of the Constitution's supporters. See WOODY HOLTON, UNRULY AMERICANS AND THE ORIGINS OF THE CONSTITUTION, note 2, supra, at 149; PAULENE MAIER, RATIFICATION, note 2, supra, at 115. Supporters of the Constitution cleverly structured voting rules so that the conventions were faced with a stark choice between ratification of the document as a whole or continuation of the unpopular Articles of Confederation. See JACK N. Rakove, Original Meanings: Politics and Ideas in the Making of the Constitution 96 (1996). Many people who ultimately supported the Constitution would have preferred a middle position involving amendments to the original draft. See PAUline MAIER, RATIFICATION, note 2, supra, at 50-69, 261, 395-96. Rhode Island, the last state to ratify the Constitution, did so only after Congress threatened a trade embargo against the state and a majority of delegates to the convention disobeyed explicit instructions from their constituents. See Bruce Ackerman \& Neil Katyal, Our Unconventional Founding, note 2, supra, at 538-39.

$4 \quad$ See, e.g., Paulene Maier, Ratification: The People Debate the Constitution, note 2, supra, at 91 (quoting Luther Martin's charge that delegates from Virginia and other "large states" sought to destroy the states and establish a monarchy.) For a comprehensive collection of Antifederalist rhetoric, see THE COMPLETE ANTI-FEDERALIST, (HERBERT J. StORING, ED. 1981).

5 Article XIII of the Articles of Confederation provided that "[T]he Articles of this confederation shall be inviolably observed by every State, and the union shall be perpetual; nor shall any alternation at any time hereafter be made in any of them, unless such alternation be agreed to in a Congress of the United States, and be afterwards confirmed by the legislatures of every State." Article VII of the Constitution violated these legal requirements in numerous ways. It authorized scrapping the "perpetual union under the Articles upon approval of only nine states, upon approval of state conventions rather than state legislatures, and without the agreement of Congress. For a comprehensive discussion, see Bruce Ackerman \& Neil Katyal, Our Unconventional Founding, note 2, supra, at 479-487. For a claim that the Constitution was legal on the ground that the Articles were a treaty that 
unquestionably marred by serious procedural irregularities, ${ }^{6}$ various political shenanigans, ${ }^{7}$ blatant coercion, ${ }^{8}$ and outright violence. ${ }^{9}$ Ratification almost didn't happen at all, and the process left many Antifederalists angry and disillusioned.

The Federalists had promised to fix some of the problems with the document by enacting amendments, ${ }^{10}$ but when Madison purported to make good on his promise by introducing a Bill of Rights in the first Congress, many Antifederalists felt betrayed again. Madison's Bill of Rights fell far short of what the Antifederalists wanted and did nothing to cure what they viewed as the Constitution's most serious defects. ${ }^{11}$

Surprisingly, despite of all this, and within a very short time, the new Constitution found wide acceptance. Perhaps because the economy quickly recovered, ${ }^{12}$ perhaps because the new Constitution

had been violated and were therefore no longer binding, see Akhil R. Amar, Philadelphia Revisited: Amendment the Constitution Outside Article V, 55 U. CHI. L. REv. 1043 (1988). For a rebuttal, see Bruce Ackerman \& Neil Katyal, Our Unconventional Founding, note 2 supra, at 539-557.

$6 \quad$ See Bruce Ackerman \& Neal Katyal, Our Unconventional Founding, note 2 supra, at 517 (rushed election violated Pennsylvania Constitution); 526 (Federalists "precipitated riots at polling places, allowing them to run off with some ballot boxes).

$7 \quad$ For example, in Massachusetts, supporters of the Constitution falsely claimed that delegates would not be paid unless they voted in favor of ratification. See WOODY HOLTON, UNRULY AMERICANS AND THE ORIGINS OF THE CONSTITUTION, note 2, supra, at 252. It is doubtful that the Constitution would have been ratified if Massachusetts had voted "no," and its "yes" vote was crucially influenced by Governor John Hancock's endorsement. The endorsement was apparently secured by the promise of leading Federalists to support his candidacy in the next gubernatorial election. See Paulene Maier, Ratification: The PeOple Debate the Constitution, note 2, supra, at 192198.

$8 \quad$ For a discussion of the pressure put on Rhode Island to ratify the Constitution, see. See Bruce Ackerman \& Neil Katyal, Our Unconventional Founding, note 2, supra, at 538-39.

${ }_{9}$ See PAULINE MAIER, RATIFICATION note 2, supra, at 100 (recounting mob attack against opponents of Constitution).

10 See Robert Allen RutLAnd, The BiRTh of THe BILl of Rights, 1776-1791, at 171, 173 (1955).

11 For example, after Madison introduced his proposals, William Grayson, Virginia's Antifederalist Senator, wrote to Patrick Henry that it was "out of [his] power to hold out to you any flattering expectations on the score of amendments." 16 DoCUMENTARY HISTORY OF THE FIRST FEDERAL CONGRESS: 1789-1791, AT 759 (Charlene Bangs Bickford et al., eds., 1992). After the amendments had been ratified by Congress, Grayson and Richard Lee, Virginia's other Senator, wrote to the Virginia General Assembly that the Amendments were "far short of the wishes of our Country" and that Grayson and Lee had been unsuccessful in "bring[ing] to view the Amendments Proposed by our Convention and approved by the Legislature." 5 THE ROOTS OF THE BILL OF RIGHTS 1186 (Bernard Schwartz ed., 1980). 12 See Michael KAMmen, A MACHINE THAT WOULD GO OF ITSELF 14-15, 70 (1986) (noting attribution of improved economic conditions to adoption of the Constitution). 
did little to obstruct what they wanted to accomplish, ${ }^{13}$ its opponents gracefully accepted their defeat and acceded to the binding force of a document they had recently and viciously attacked. ${ }^{14}$

On conventional accounts, in the years since, the Constitution has served as the sacred text of our civil religion. ${ }^{15}$ People have fought passionately about what it means, but its authority and goodness have served as common ground. It has come to symbolize the possibility of government limited by law and the ability of an ethnically, politically, and culturally diverse populace to come together for the common good. To oppose the Constitution is to oppose the American experiment itself, and to oppose America is to be outside the realm of reasonable discourse. ${ }^{16}$

And yet, through two centuries of hagiography for the founders and worship of the text that they produced, atheists and agnostics have survived. Skeptics have continued to challenge the goodness, enforceability, legitimacy, and workability of the Constitution. It is startling how deep this counter-narrative runs. Skepticism even managed to worm its way into the Federalist Papers, which the Supreme Court often treats as the Talmud of our constitutional Bible. ${ }^{17}$ Since then and throughout our history, many of our most revered political figures have expressed doubts about the Constitution. Constitutional skepticism has been at the heart of some of our most important political battles, and it has preoccupied some of our leading political thinkers. It is as American as apple pie.

The aim of this article is to recover and reevaluate the tradition of constitutional skepticism. More is at stake here than merely complicating the historical record. The argument for the Constitution itself hangs in the balance. In part this is true because, on the merits, the skeptics have a point. Perhaps

13 See id, at 72 ("By the mid-nineteenth century, the term 'constitutional' ... had become a convenient camouflage for moral compromise and political expediency.")

14 See PAUline MAIER, RATIFICATION, note 2, supra, at 432 ("After Congress declared the Constitution ratified and called the first elections, the country rallied behind the new Constitution.")

15 See, e.g., Thomas C. Grey, The Constitution as Scripture, 37 STAN. L. REV. 1, 3 (1984) (noting that the Constitution has been "virtually from the moment of its ratification a sacred symbol"); SANFORD LEVINSON, CONSTITUTIONAL FAITH 11 (2011) (quoting Irving Kristol's statement that the flag, the Constitution, and the Declaration of Independence "constitute the holy trinity of what Tocqueville called the American 'civil religion."') 16 See, e.g., id., at 252-54.

17 See $\mathrm{pp} \mathrm{xx}-\mathrm{xx}$, infra. 
more significantly, however, a revival of the skeptical tradition makes it possible to talk seriously about whether they have a point or not.

To see why this is so, we need to rehearse how the argument over skepticism has gone so far. On the face of things, it seems bizarre to bind ourselves to a very old and difficult-to-amend text, full of idiosyncrasies, and written by people who had no inkling of the economic, political, material, and moral climate of twenty-first century America. ${ }^{18}$ Paradoxically, constitutional obedience violates the first three words of the Constitution itself. Instead of empowering "We the [living] People," it empowers They the dead People.

Despite these obvious problems with constitutional obedience, modern skeptics rarely get anything like a full hearing. To the extent that anyone pays attention to them at all, they are considered cranks, too far outside the mainstream to take seriously. This reaction is more of a predisposition than anything resembling a refuting argument, but a few defenders of constitutionalism have turned the predisposition into an argument. They insist that the long tradition of past respect for the Constitution counts as a reason for present respect. On this view, and despite what Jefferson claimed, ${ }^{19}$ prior generations are not like a foreign country exercising imperialist power over the present. On the contrary, they are a (concededly constructed) part of "us" because political identity, like personal identity, makes sense only diachronically. There is a continuing, coherent constitutional narrative that extends backward to the moment of founding. "We the people" includes people living and dead because living peoples are necessarily formed by practices, institutions, and habits of thought inherited

18 I make an extended argument for this proposition in LOUIS MICHAEL SEIDMAN, ON CONSTITUTIONAL DISOBEDIENCE (2013).

19 See "Thomas Jefferson to James Madison, September 6, 1789, with Copies and Fragment," in VI THE WORKS OF ThOMAS JefFerson 3 (Paul Leicester Ford, ed., 1904) ("by the law of nature, one generation is to another as one independent nation is to another.") 
from past generations. It is just this inheritance that defines a People, gives it autonomy, and separates it from other Peoples. ${ }^{20}$

If our constitutional tradition forms the backbone of our national identity and gives meaning to our collective existence over time, then insisting that we give up on it is asking quite a lot. But need we conceive of constitutionalism this way? The starting point for this article is that there is usually a choice about how we construct our past. The choice is not boundless, or at least it is not boundless given contingent cultural constraints on our imagination at any particular moment. It is hard for us presently to imagine our history as defined by, say, the gradual emergence of a Confucian social order immanent in founding choices. But even if constrained, there is more freedom than we often realize. ${ }^{21}$

Constitutional skepticism offers an alternative way to construct our history - a construction that is also consistent with the historical data and within the possibilities of imagination, or at least so I argue. This article is intended as a first stab at fostering this reimagination. To be clear, I make no claim that this narrative is the only way to make sense of our past. My project is "constructivist" in the sense that it chooses one of many interpretations so as to make the best of our history. ${ }^{22}$ Of course, reasonable people will disagree with my normative assessment of which interpretation makes that history the "best." My aim is to lay the groundwork for just such a discussion - a discussion that cannot take place so long as the prevailing narrative of constitution-worship is the only one available. What follows, therefore, is not so much an argument for constitutional skepticism as a necessary prolegomenon to such an argument.

Part I consists of a brief history of skepticism running from before the founding to the modern period. My aim here is not to provide anything like a complete description of the historical actors, texts,

20 For the best articulation of this view, see generally JED RUBENFELD, FREEDOM AND TIME: A THEORY OF CONSTitutional Self-Government (2001).

21 See generally BenEdict ANDERSON, IMAGINEd COMMUNITIES: REFLECTIONS ON THE ORIGIN AND SPREAD OF NATIONALISM (1991).

22 In this sense, but perhaps only in this sense, my project parallels Ronald Dworkin's famous effort to provide a constructivist account of law. See generally R.M. DWORKIN, LAW'S EMPIRE (1986). 
and events that I discuss. Instead, I link together familiar episodes and arguments that stretch across our history so as to demonstrate that they are part of a common narrative that has been crucial to our self-identity.

A fair objection to this enterprise is that I have lumped together a variety of arguments that are in fact separate and unrelated. Part II responds to this worry by disentangling the various strands of skeptical argument. People who have had doubts about the Constitution have not always shared the same doubts. Some skeptics have argued that the Constitution produces evil outcomes and ought to be resisted to the extent that it is evil. A related, but analytically distinct claim is that the Constitution binds us to the "dead hand" of the past and, so, is fundamentally undemocratic. Other critics have focused on the means of constitutional enforcement. They have claimed that judicial review is deeply undemocratic and inconsistent with rule by "We the People." Still other critics have made something like the opposite point - that the Constitution cannot be enforced and constitutes no more than "parchment barriers."

There is at best a complex relationship between these claims. Perhaps they even contradict each other. Moreover, there is a similarly complex relationship between the various strands of constitutional skepticism and a more global skepticism about law and about morals. Despite this complexity, the argument of Part II is that the various strands of constitutional skepticism share a common core. At base, all forms of constitutional skepticism rest on doubts about whether moral and political disagreement can be bridged by a legal text. Those doubts, in turn, are grounded on a rejection of global moral skepticism and on deep strands of American thought that emphasize the possibility of moral knowledge.

In Part III, I very briefly suggest some preliminary conclusions about how we should view constitutional skepticism. I argue that there are reasons to think that a dose constitutional skepticism might mitigate some of our current political dysfunction. 
I conclude with the suggestion that the mere recognition of the possibility of constitutional skepticism undermines one of the main arguments against it.

\section{A Brief History of Constitutional Skepticism}

As I hope to demonstrate in the Part that follows, the United States enjoys a rich tradition of thought and action grounded in skepticism about constitutionalism in general, about the worth of the American Constitution in particular, and about modes by which the American constitution might be interpreted and enforced. Before exploring this tradition, however, I must emphasize several limitations of my project.

First, my aim is not to provide a comprehensive account of this tradition. I have tried to be accurate and to avoid over simplification, but a comprehensive account would require book length treatments of every topic that I cover below. Instead, my goal is to link together a group of disparate individuals and episodes so as to tell a coherent story about our national ethos. Accordingly, I have emphasized those thinkers and events that evince common themes useful for the organization of skeptical thought.

Second, the tradition that I describe, while vibrant and important, has also often been subterranean. Because it undermines the official narrative, it sometimes finds expression in things said softly or indirectly or in things left entirely unsaid. Only occasionally, but at nonetheless dramatic and important historical moments does it receive full-throated endorsement. More usually, one has to read texts and events carefully, but, I hope, not tendentiously, to find a submerged message.

Third, I make little effort in the pages that follow to recount popular attitudes toward the Constitution. ${ }^{23}$ This failure is only partially attributable to my lack of the methodological skills necessary to accomplish this task. For better or worse, unifying national myths and narratives tend to be formed by recollection of great episodes in our history and of the great men and women who made them.

23 For the leading effort to do so, see MichaEL KAMMEN, a MACHINE THAT Would Go Of ITSELF: THE CONSTITUTION IN AMERICAN CULTURE (1987). 
Because I am interested in reconstructing a national narrative, I have concentrated my attention on the sorts of people and events that have formed it.

Finally, it is worth emphasizing again the constructivist nature of this project. The skeptical narrative that I relate is one of many that can be made to fit the historical data. The data can demonstrate that this narrative possibility exists, but cannot alone dictate the choice between narratives.

\section{A. Constitutional Skepticism before the Constitution}

Even before there was a Constitution, there was constitutional skepticism. The preRevolutionary period was marked by the growth and vibrancy of constitutional theory. Spurred by the emergence of enlightenment rationality and the decline in the legitimacy of divine rights monarchs, political thinkers such as Locke, Grotius, Pufendorf, Burlamaqui, Vattel, and Rutherford developed the idea of a system of natural rights that would define and limit government power. ${ }^{24}$ The fundamental and powerful idea was that people could formulate a set of basic principles that would serve to regulate and control ordinary politics and, so, legitimate and limit the exercise of coercive government power. In colonial America, these ideas were given concrete instantiation with the writing of corporate charters creating the various colonies ${ }^{25}$ - charters that eventually morphed into state constitutions. ${ }^{26}$

It was natural that when tensions emerged between colonial America and England, Americans expressed their dissatisfaction in constitutional terms. Although they did not rely on a written constitution, they insisted that the "rights of Englishmen" trumped ordinary positive law and that

24 See, e.g., Thomas C. Grey, Origins of the Unwritten Constitution: Fundamental Law in American Revolutionary Thought, 30 STAN. L. REV. 843, 860-65 (1978).

25 See generally Mary Sarah Bilder, The Transatlantic Constitution: Colonial legal Culture AND the EMPIRE (2004)

26 For a discussion, see LARRY KRAMER, THE PEOPLE THEMSELVES 50-55 (2004). For a brief history of the development of state constitutions, see "Editors Introduction" in ALEXANDER HAMILTON, JOHN JAY \& JAMES MADISON, THE FEDERALIST XXIII-XXXI (The Gideon Edition, George W. Carey \& James McClellan eds., 2001). 
neither Parliament nor the King had unlimited power over them. ${ }^{27}$ Even before independence was achieved, the first impulse of the colonial states was to reduce to writing their understandings of how government would function. The result was the Articles of Confederation. Around the same time, there was a flurry of constitution writing at the state level.

1. Hobbes. At the very moment when constitutional creativity was in full bloom, though, various strands of skepticism emerged, each of which finds voice even today. Much of the skepticism has its roots in social contract theory itself. At least conventionally, the theory begins with Thomas Hobbes' famous description of an anarchic and brutal state of nature. ${ }^{28}$ In the Hobbesian tradition, even the strong have an interest in coming to an agreement on a government that would control otherwise unconstrained violence. ${ }^{29}$ But, importantly, Hobbes did not believe that the social contract provided many important limits on government power. On the contrary, he thought that a government powerful enough to constrain violence would have to be powerful enough to control the lives of its citizens. ${ }^{30}$ On the Hobbesian account, the trade was worth it so as to avoid the nightmare of universal depredation.

The Hobbesian account supports a familiar argument in favor of constitutionalism. If the Constitution is treated as an instantiation of the social contract, then the commonly expressed fear that

27 See generally Thomas C. Grey, Origins of the Unwritten Constitution: Fundamental Law in American Revolutionary Thought, note 24, supra.

$28 \quad$ In a well-known passage, Hobbes wrote that in a state of nature

there is no place for industry, because the fruit thereof is uncertain: and consequently no culture of the earth; no navigation, nor use of the commodities that may be imported by sea; no commodious building; no instruments of moving and removing, such things as require much force; no knowledge of the face of the earth; no account of time; no arts; no letters; no society; and, which is worst of all, continual fear, and danger of violent death; and the life of man, solitary, poor, nasty, brutish, and short.

Thomas Hobbes, LeViathan: OR The Matter, Forme ANd POWer of A COMmonWealth ECClesiasticall ANd Civil 100 (Michael Oakeshott ed., 1962).

29 See Murray Forsyth, “Hobbes' Contractarianism: A Comparative Analysis, in THE SOCIAL CONTRACT FROM HoBbES to RAWLS (David Boucher \& Paul Kelly eds, 1994) at 39 (on Hobbes theory, state necessary to meet people's practical earthly needs).

30 See id., at 41 (Hobbes' state granted full autonomy); Mark Tushnet, Anti-Formalism in Recent Constitutional Theory, 83 MicH. ,. REV. 1502, 1504 (1985) (although rulers would use their power for selfish purposes life with the Leviathan would still be better than life without it). 
society would devolve into chaos if constitutional obligation eroded has clear Hobbesian roots. But Hobbes' analysis also undermines a key part of the standard story. An essential element of the ideology of constitutionalism is that constitutions constrain government power and, so, prevent not only chaos but also tyranny. ${ }^{31}$ Hobbes forces us to ask skeptical questions about whether and how constitutions can serve this function. How, exactly, will words on a piece of paper stop self-interested rulers vested with the power necessary to prevent a war of all against all from turning into tyrants?

This worry runs throughout the skeptical tradition, finding expression, for example, in Madison's ${ }^{32}$ and Hamilton's ${ }^{33}$ belittling of "parchment barriers," in Holmes insistence that judges should not try to use the Constitution to obstruct "the natural outcome of a dominant opinion," ${ }^{34}$ in Learned Hand's warning that the Constitution could not be expected to safeguard liberty, ${ }^{35}$ and in the work of modern scholars like Daryl Levinson ${ }^{36}$ who doubts that respect for constitutional law meaningfully constrains government actors, and Adrian Vermeule ${ }^{37}$ who explores "second best" constitutionalism that actors must adopt when other actors fail to follow constitutional norms.

2. Locke. John Locke's version of social contract theory was more optimistic. For Locke, people in a state of nature live in freedom and independence ${ }^{38}$ and resolve their disputes by resort to reason. ${ }^{39}$

31 See, e.g., Gordon Schochet, "Introduction: Constitutionalism, Liberalism, and the Study of Politics" in CONSTITUTIONALISM (J. RONALD PENNOCK \& JOHN H CHAPMAN, EDS. 1979) AT XX (fundamental principle uniting all theories of constitutionalism is that "governments exist only for specified ends and properly function only according to specified rules".)

32 See The Federalist No. 48 (Madison) in The Federalist: The Gideon Edition (George W. CARey \& James MCCELLAN, EDS. 2001) at 256 (arguing against trust in "parchment barriers.")

33 See "The Federalist No. 73" (Hamilton) in The Federalist: THE GIDEON EDITION, note 32, supra, at 380 (insufficiency of "a mere parchment delineation.")

$34 \quad$ Lochner v. New York, 198 U.S. 45, 76 (1905) (Holmes, J., dissenting).

35 Learned Hand, "The Spirit of Liberty" in THE SPIRIT OF LIBERTY 190-91 (3d ed., 1960) ("Liberty lies in the hearts of men and women; when it dies there, no constitution, no law, no court can save it.") ${ }_{36}$ See Daryl Levinson, Parchment and Politics: The Positive Puzzle of Constitutional Commitment, 124 HaRV. L. REV . 657 (2011).

37 See Adrian Vermeule, Foreword: System Effects and the Constitution, 123 HARV. L. ReV. 4 (2003). 38 See JOHN LOCKE, TWO TREATISES OF GOVERNMENT 189 (1821) (in state of nature, all men are in "a state of perfect freedom to order their action and dispose of their possessions and persons as they think fit, within the bounds of the law of nature, without asking leave, or depending upon the will of any other man.") (emphasis in original). 
However, the obligation we owe to God, to each other, and to ourselves to preserve mankind cannot be fully met in the absence of civil authority. When individuals join society, they consent to give up some of their rights so as to ensure meaningful enforcement of other rights. ${ }^{40}$

Unlike the Hobbesian account, the Lockean social contract has strong limits. Whereas Hobbes saw government as no more than a means of establishing earthly peace, for Locke it was superimposed on the kingdom of God that already existed in the state of nature. Whereas Hobbes therefore treated the political order as essentially omnipotent, Locke thought that government power was conditional. It is premised on the continuing consent of the governed, ${ }^{41}$ and when the state no longer protects the rights it was intended to preserve, the consent is vitiated. ${ }^{42}$ When governments violate those rights, its citizens have the right to take up arms. ${ }^{43}$

There can be no doubt that Locke's constitutional contractualism influenced the framing of the American constitution, but the implications it held for future constitutional obligation are more ambiguous. Locke, himself, was doubtful that law could or should entirely constrain executive power. He recognized an executive prerogative to act in violation of the law when necessary to deal with unanticipated events or pressing necessities. ${ }^{44}$ No doubt, he thought that these circumstances were exceptional, but this leaves open the famous problem of who gets to define the exception and whether, once this power of definition is granted, the power can be constrained. ${ }^{45}$

\footnotetext{
39 See id, at 191 (reason is law of nature).

$40 \quad$ Id., at 259-62.

41 Id. at 287 ("It is plain mankind never owned nor considered any ... natural subjection that they were born in, to one or the other that tied them, without their own consent to a subjection of them and their heirs.") (emphasis in original).

42 Id, at 299 ("The power of the society . . can never be supposed to extend further than the common good.") (emphasis in original).

$43 \quad$ See id., at 322 ("in all state and conditions, the true remedy of force without authority is to oppose force to it. The use of force without authority always puts him that uses it into a state of war, as the aggressor, and renders him liable to be treated accordingly.") (emphasis in original).

$44 \quad$ See id., at 322-323.

45 The seminal work is CARL SCHMITT, DICTATORSHIP (English ed. 2014).
} 
The problem is not merely theoretical. It has taken concrete form throughout American history.

As we shall see, many American Presidents have asserted a power to transcend normal constitutional limits when there are strong pragmatic reasons to do so. ${ }^{46}$ Of course, these Presidents often (but importantly not always) attempted to reconcile these powers with the Constitution by reading emergency powers into the document. But this reconciliation comes with a necessary price: it weakens the claim that constitutions meaningfully constrain executive discretion and so, feeds back into Hobbesian skepticism.

Even putting aside the problem of the executive prerogative, Locke's theory has the potential to destabilize existing constitutions. Because the theory rests on a consent that could always be withdrawn and on the potential gap between government that actually exists and the ends of God, ${ }^{47}$ it provides more obvious support for revolution than for constitutional obedience. ${ }^{48}$ It is therefore no surprise that Locke is more extensively paraphrased in the Declaration of Independence than in the Constitution.

Moreover, the most obvious connection between Lockean theory and the Constitution's framing history actually undermines constitutional obligation. At the beginning of the Philadelphia convention, the framers were faced with the embarrassment that the congressional resolution authorizing the proceedings had permitted them to meet for "the sole and express purpose of revising the Articles of Confederation." 49 Worse yet, the Articles themselves required that amendments be adopted unanimously by all thirteen state legislatures. ${ }^{50}$ Yet in the earliest days of the convention, the framers

\footnotetext{
$46 \quad$ See $\mathrm{pp} x \mathrm{x}$, infra.

47 See JOHn LOCKE, TWo TREATISES Of GOVERNMENT note 37, supra, at 305 ("The rules that [legislators] make for other men's actions must . . . conform to the law of nature, i.e., to the will of God of which that is a declaration and the fundamental law of nature being the preservation of mankind, no human sanction can be good or valid against it") (emphasis in original).

48 See note 43, supra.

49 See I Jonathan Elliot, The Debates in the SeVeral State Conventions on the Adoption of the Federal Constitution as Recommended by the General Convention at Philadelphia in 1787 at 120 (2d ed., 1836) [Hereinafter cited as DEBATES)

50 See note 5, supra.
} 
determined to scrap the Articles entirely. By the end of the convention, they had decided that the new constitution would be deemed ratified when adopted by state conventions (not state legislatures) in only nine of the thirteen states.

The framers' justification for this blatant constitutional violation was drawn directly from Locke. ${ }^{51}$ For example, at the convention, Roger Sherman objected to the proposed form of ratification on the ground that "the Articles of Confederation [provided] for changes and alternations with the assent of Congress and the ratification of State legislatures." ${ }^{52}$ George Mason responded that constitutions "are derived from the people. This doctrine should be cherished as the basis of free government. ${ }^{\prime 53}$ James Wilson later made a similar point when defending the Constitution before the Pennsylvania ratifying convention: because government rest on popular consent, "[t]he people have a right ... to form ... a general government. ... This is the broad base on which our independence was placed. On the same certain and solid foundation [the new constitution] is erected." 54

It is dangerous for defenders of constitutional obligation to traffic in this argument. Two destabilizing possibilities are immediately apparent. First, whereas the Hobbesian social contract was justified solely on the ground that it avoided chaos, the Lockean contract was meant to protect other goods. It follows from this Lockean premise, that preservation of social order alone might be insufficient to justify constitutional obedience. There might be a gap between any particular constitution and the aims that legitimate it, and this gap might warrant departure from constitutional obligation. Thus, because the Articles of Confederation were no longer serving the ends it was written to achieve, the

51 The justification overlaps with the argument for an unconstrained "constituent power" associated with thought developed during the French Revolution. For a discussion, see Mark Tushnet, Constitution Making: An Introduction, 91 TEX. L. REV. 1983, 1985-91 (2013).

52 I THE ReCORds of THE Federal Convention OF 1787 at 122 (Max Farrand, ed, 1911) (hereinafter cited as The RECORDS OF THE FEDERAL CONVENTION).

53 II THE RECORDS OF THE FEDERAL CONVENTION 88-89

$54 \quad$ III DEBATES 455-457. 
Framers felt justified in ignoring them. ${ }^{55}$ But the very argument the Framers used to support their new constitution might also be advanced to defy $\mathrm{it}^{56}$, as indeed both southern secessionists and northern abolitionists did during the run up to the Civil War. ${ }^{57}$

Second, arguments from popular consent raise difficulties about how the consent is manifested and how we know when it is withdrawn. If the actual American Constitution is conceptualized as the social contract, then there are obvious problems with its democratic pedigree. No women or people of color and few people without property voted for it. ${ }^{58}$ And the problem runs deeper than this. David Hume, Locke's contemporary who probably influenced the framers more than Locke himself, rejected social contract theory in part on the ground that even a contract consented to by contemporaries could not bind future generations. ${ }^{59}$

On one interpretation, Locke's social contract was an actual historical agreement that brought governments into being. Hume was almost certainly right in rejecting this version of the theory, not just because of the inter-generational problem, but also because it is an inaccurate account of how governments actually arise. ${ }^{60}$ Locke's position might be rescued from Humean skepticism if the contract

$55 \quad$ In essence, this is the argument that Madison made in Federalist 43 when he responded to the complaint that the Articles of Confederation, "the solemn form of a compact among the states," was being superceded without the unanimous consent of the parties to it.

The ... question is answered at once by recurring to the absolute necessity of the case; to the great principle of self-preservation; to the transcendent law of nature and of nature's God, which declares that the safety and happiness of society, are the objects at which all political institutions aim, and to which all such institutions must be sacrificed."

Federalist No. 43 (Madison) in in in The Federalist: The GIDEON EdITION, note 32, supra, at 229.

56 As one opponent of the new Constitution argued, "the same reasons which you now urge for destroying our present government, may be urged for abolishing the system which you now propose to adopt." Quoted in HERBERT J. StORING, WHAT THE Federalists WeRE For 8 (1981).

$57 \quad$ See $\mathrm{pp} \mathrm{xx}-\mathrm{xx}$, infra.

58 See note 3, supra.

59 See DAVID HUME, Political EsSAYS 189 (Knud Haakonssen, ed., 1994) (“being so ancient, and being obliterated by a thousand changes of government and prices, it cannot now be supposed [that the original contract retains] any authority.... [B]esides that this supposes the consent of the fathers to bind the children, even to the most remote generations (which republican writers will never allow) . . it is not justified by history or experience, in any age or country of the world").

60 Hume is not unambiguous on this score. At one point, he writes that 
is conceptualized instead as a thought experiment. Perhaps the contract is what reasonable people would agree to in a state of nature. But this merely hypothetical consent hardly constitutes the sort of robust justification provided by actual consent from "We the People." ${ }^{61}$ Moreover, this version of the theory again opens up the possibility of a dangerous gap between a hypothetical social contract and any actual, real-world constitution. If it is the hypothetical contract that provides legitimacy, then any real constitution that departs from this contract is illegitimate. And matters are made only worse by the fact that in a diverse society, even people who believe in social contract theory are bound to disagree among themselves about what terms must be included in the contract.

3. The contestable constitution. These difficulties in grounding contemporary ideas about constitutionalism in Locke go some way toward explaining what otherwise seems paradoxical about how eighteenth century Americans thought about constitutional law. On the one hand, they took constitutionalism and constitutional violation very seriously. Rhetoric of the period is full of constitutional claims and assertions of constitutional rights. ${ }^{62}$ Yet on the other hand, Americans seemed

It is probable, that the first ascendant of one man over multitudes began during a state of war; where the superiority of courage and of genius discovers itself most visibly. . . The long continuance of that state, an incident common among savage tribes, enured the people to submission; and if the chieftain possessed as much equity as prudence and valour, be became, even during peace, the arbiter of all differences, and could gradually, by a mixture of force and consent, establish his authority.

Id. at 22 .

But in another essay, he writes that

When we consider how nearly equal all men are in their bodily force, and even in their mental powers and faculties, till cultivated by education; we must necessarily allow, that nothing but their own consent could, at first, associate them together and subject them to any authority.... If this, then, be meant by the original contract, it cannot be denied, that all government is, at first, founded on a contract, and that the most ancient rude combinations of mankind were formed entirely by that principle.

Id., at 187-88.

61 For a detailed argument along these lines, see RANDY BARNETT, RESTORING THE LOST CONSTITUTION: THE PRESUMPTION OF LIBERTY 11-30 (2004).

62 See, e.g., GoRdON WOOD, THE RADICALISM OF THE AMERICAN REVOLUTION XX-XX (1991) 
quite content with a system that lacked a clear means of constitutional enforcement or authoritative

resolution of constitutional controversy. As Larry Kramer summarizes the prevailing zeitgeist:

[The] constitutional system ... was self-consciously legal in nature, but in a manner foreign to modern sensibilities about the makeup of legality.... Eighteenth-century constitutionalism was less concerned with quick, clear resolutions. Its notion of legality was less rigid and more diffuse - more willing to tolerate ongoing controversy over competing plausible interpretations of the constitution, more willing to ascribe authority to an idea as unfocused as "the people." ${ }^{63}$

No American thinker better embodied this conception of constitutionalism than Thomas Paine.

Paine famously claimed that "In America, the law is king," ${ }^{64}$ and there can be no doubt that he thought that the Constitution was the law. ${ }^{65}$ Yet Paine also believed in unfettered representative democracy. He followed Hume ${ }^{66}$ and foreshadowed Jefferson ${ }^{67}$ in insisting on the fundamental illegitimacy of one generation binding another. ${ }^{68}$ How can these positions be reconciled?

Paine's work is maddeningly vague, ${ }^{69}$ but on at least one understanding, it takes the destabilizing potential of Lockean theory very seriously. On this view, the Constitution is, indeed, law, but it maintains that status only so long as it has the active consent of the people. This means that the Constitution is always revisable and subject to continual contestation. Ultimately, it is guardian of, rather than the enemy of, full throated representative democracy.

This is constitutionalism of a sort, but it is a constitutionalism at war with the standard story as we have come to understand it. Paine's constitution provided neither settlement nor hierarchical

\footnotetext{
63 Larry Kramer, The People Themselves 30 (2004).

64 ThOMAS Paine, "Common Sense" in Collected Writings 34 (Eric Foner ed., 1995)

65 See, e.g., THOMAS PAINE, "Rights of Man: Being an Answer to Mr. Burke's Attack on the French Revolution, 1791) in id., at 468, 574 ; Robin West, Tom Paine's Constitution, 89 VA. L. ReV. 1413, 1415 (2003) (noting that Paine "repeatedly characterized the Constitution as 'law.'”).

66 See note 59, supra.

67 See note 19, supra; pp xx-xx, infra.

68 See, e.g., THOMAS PAINE, note 64, supra, at 438-39, 594-95. . As Robin West characterizes his position,

Paine's faith in unfettered representative democracy was . . robust and uncompromising; he believed fervently that we, meaning each generation, should be ruled by our own representatives, rather than by our ancestors. He despised the idea of rule of the living by the dead as much as he despised monarchy ...

Robin West, Tom Paine's Constitution, note 65, supra, at 1415.

69 For a description of a seeming contradiction in his work and an argument that resolves it, see id., at 1418.
} 
ordering. It was a site for contestation and civic engagement, not a means of permanently resolving disputes and defusing destabilizing controversy.

As foreign as it may seem to us today, this view of constitutionalism seems to have been quite common in the late eighteenth century. For example, state constitutions were often adopted by ordinary legislative means, ${ }^{70}$ and some leading authorities believed that they could be repealed by statute. ${ }^{71}$ Constitutional enforcement was not the job of politicians or judges, but of the people themselves. Popular enforcement, in turn, was facilitated by the very short terms of office for legislatures, narrow jurisdiction for courts, and truncated powers for executives. ${ }^{72}$

Eighteenth century Americans were able to conceptualize constitutionalism in this way because they lived in an era of constitutional creation, rather than constitutional obedience. The act of creating a constitution is exhilarating and liberating. It is an assertion of generational autonomy. As John Adams observed,

How few of the human race have ever enjoyed an opportunity of making an election of government, more than of air, soil, or climate, for themselves or their children! When, before the present epocha, had three millions of people full power and a fair opportunity to form and establish the wisest and happiest government that human wisdom can contrive. ${ }^{73}$

So long as Americans were creating constitutions for themselves, there was no contradiction between constitutionalism on the one hand and popular sovereignty on the other. But a problem arises when, as Adams mentions, constitutional creators began writing not just for themselves but also for their children. When constitutional aspirations have congealed into a text and been immunized from easy revision, the struggle for generational autonomy begins to seem like a zero sum game. Autonomy for one generation is gained at the expense of subservience of another, and constitutionalism becomes

70 See Jack Rakove, Original Meanings: Politics and Ideas in the Making of the Constitution 97 (1996); LARRY KRAMER, THE PEOPLE THEMSELVES 57 (2004).

71 Both Jefferson and John Adams apparently took this view. See id.

72 See, e.g., id. at 59.

73 John Adams, "Thoughts on Government" in I AMERICAN Political WRITING DURING THE Founding ERA 17601805 at 408-09 (Charles S. Hyneman \& Donald S. Lutz, eds. 1983) . 
an exercise in domination as well as liberation. The efforts by the founding generation to deal with this problem gave to rise to a new justificatory story, as well as new varieties of skepticism.

\section{B. Skepticism at the Founding}

As the preceding discussion demonstrates, American constitutionalism was founded on a contradiction. Late eighteenth century America was a revolutionary state. When the Framers met in Philadelphia, memories of the uprising against British rule were still fresh. Importantly, and despite the colonists' assertion of the "rights of Englishmen," that uprising was illegal under then-existing law. It therefore had to be justified by theories that rejected the binding force of that law -- theories like the one outlined in the Declaration of Independence. ${ }^{74}$ These theories did not magically disappear with the victory at Yorktown. A generation formed by rebellion against British authority was not about to accept meekly the claims of new rulers. Hence, the free-form, populist, nonauthoritarian constitutionalism that dominated America's early years.

But the country needed stability to grow and thrive. It therefore could not avoid the dilemma faced by all revolutionary states: How does one establish that the revolution is over? How can law and order be reestablished once it has been disrupted ${ }^{75}$ Ruling elites somehow had to make clear that rebellion against the British was one thing, but rebellion against the new status quo - Shays' Rebellion, for example - was another thing altogether. The country had to find a way to suppress, compartmentalize, or rationalize the illegality of its own birth in order to establish the new legality.

On conventional accounts, the drafting and ratification of the Constitution resolved this contradiction. Popular ratification put an end to the fluidity and destabilization of revolutionary constitutionalism and legitimated rigid rules that established fixed boundaries between different

\footnotetext{
74 See Gordon WoOd, THE RAdICALISM OF THE AMERICAN ReVOLUTION, note 60, supra, at xx 75 For a general discussion of the problem, see Bruce Ackerman, Storrs Lectures: Discovering the Constitution 93 YALE L. J. 1013, 1019-20 (1984).
} 
branches, governments, and spheres. Writing within a decade of ratification, Justice James Iredell

explained how text congealed the law and put an end to disputation:

It has been the policy of all the American states, ... and of the people of the United States, ... to define with precision the objects of the legislative power, and to restrain its exercise within marked and settled boundaries. If any act of congress or of the legislature of a state, violates those constitutional provisions, it is unquestionably void. ... If, on the other hand, the legislature of the Union or the legislature of any member of the Union, shall pass a law within the general scope of their constitutional power, the court cannot pronounce it to be void, merely because it is, in their judgment contrary to the principles of natural justice. ${ }^{76}$

No doubt, some of the Constitution's framers hoped that constitutional text would produce this sort of certainty and stabilization. Their success in accomplishing this goal is less clear. In fact, the effort to fix constitutional discourse had something like the opposite effect. For all its imprecision and destabilizing potential, pre-ratification constitutionalism reconciled the demands of popular sovereignty and constitutional law. When the Constitution was stabilized by a legal text and immunized from easy revision, this reconciliation unraveled. The result was the emergence of a variety of worries, critiques, and contradictions that remain with us today. This Section examines the way in which these problems influenced the debate over ratification, the adoption of the Bill of Rights, and the thought of Thomas Jefferson.

1. The Antifederalists. The Antifederalist campaign was the most sustained and unambiguous attack on the American Constitution in our history. As the political scientist Herbert Storing meticulously demonstrated, ${ }^{77}$ it was also one of the great lost causes in American history. Leaders of the campaign created a huge volume of argument and theory, some of which deserves to be ranked among the classics of political thought. ${ }^{78}$ And the campaign almost succeeded. ${ }^{79}$

\footnotetext{
$76 \quad$ Calder v. Bull, 3 U.S. 386, 398 (1798) (Iredell, J., concurring).

77 See generally HERBERT J. StORING, WhAT the ANTI-FEDERALISTS WERE FOR (1981).

78 It is collected in THE COMPLETE ANTI-FEdERALIST, (HERBERT J. STORING, ED. 1981).

79 See Pauline Maier, Ratification: The People Debate the Constitution, 1787-88 at 115-16 (2010) (recounting contemporary view that ratification was "a lost cause.")
} 
It is no surprise, then, that the Antifederalist campaign produced a treasure trove of argument against the Constitution - argument that still resonates some two centuries later. The Antifederalist distrust of the federal power, celebration of localism and decentralization, worry about militarization and high taxes, and fear of a remote political class ${ }^{80}$ all play an important role in modern American politics. ${ }^{81}$

But although Antifederalist writing provides a sustained critique of the Constitution, most of it was not explicitly directed against constitutional obligation per se. If anything, Antifederalists complained that the Constitution was insufficiently binding - that its vague and sweeping language constituted an open invitation to the federal government to seize vast swaths of power. ${ }^{82}$ Ironically, though, if one looks carefully beneath the surface, these complaints not only undermine the particular constitution written in Philadelphia but also raise important skeptical questions about the constitutional enterprise itself.

First, Antifederalists complained repeatedly and vociferously about the problem of constitutional origin. ${ }^{83}$ As discussed above, the constitutional convention ignored the legal requirements imposed by the Articles of Confederation. ${ }^{84}$ The problems of fairness and legality grew only more serious as the ratification process proceeded. Individual state conventions were marred by serious irregularities, efforts to short-circuit or terminate debate and deliberation, and, in a few cases,

80 See,e.g., Herbert Storing, What the ANTI-Federalists Were For 15-23 (1981) (localism); PAUline Maier, Ratification: The People Debate the Constitution, 1787-88 at 110, 425 (taxes); id. at 264-65 (representation); id. at 245 (standing armies).

81 See Herbert Storing, What the ANTI-FEderalists Were For 3 (1981) ("The political life of the community continues to be a dialogue, in which the Anti-Federalist concerns and principles still play an important part.") 82 See, e.g., Pauline Maier, Ratification: The People Debate the Constitution, 1787-88 at 81 (2010) (noting objection that constitutional grants of power to Congress were "so open-ended that it was meaningless to say its powers were carefully defined and limited.")

83 See id. at 7 (1981) (noting that the Anti-Federalists "often objected even to entering into debate on the Constitution because of legal irregularities in the Proceedings of the Philadelphia Convention.")

$84 \quad$ See pp $\mathrm{xx}-\mathrm{xx}$, supra. 
violent intimidation. After a critical mass of states had voted to ratify the Constitution, the holdouts were threatened with economic retaliation and collapse if they did not go along. ${ }^{85}$

Of course, the Constitution's opponents focused on the particular problems with the measure they opposed, but the origins problem they identified is generalizable. All constitutions break with the legal past, and all of them therefore raise questions about their own legal legitimacy. ${ }^{86}$ In our own case, throughout American history, the original sin of the framers has destabilized the myth of immaculate conception. As Bruce Ackerman has forcefully argued, there is no reason to suppose that only one generation had the wisdom and intelligence to engage in the task of constitutional invention. ${ }^{87}$ The ratification process therefore raised deeply destabilizing questions about whether we should emulate the Framers' own example of disobedience to others, or slavishly follow their hypocritical insistence on obedience to them.

The substantive complaints of the Antifederalists feed a second, more general constitutional skepticism. It is a mistake, made too often in modern scholarship, to reduce the fight over the Constitution to a simple ideological clash. There were many cross-cutting interests - some of them quite narrow and ugly - that influenced the positions people on both sides took on ratification. Still, the most basic objection to the new Constitution - that it expanded federal power at the expense of local politics- had a clear ideological valence.

In the late eighteenth century, American government was remarkably responsive to the views of the electorate. The federal government was very weak, and most power was exercised on the state level. State legislators, in turn, served very short terms, and, by modern standards, executives and

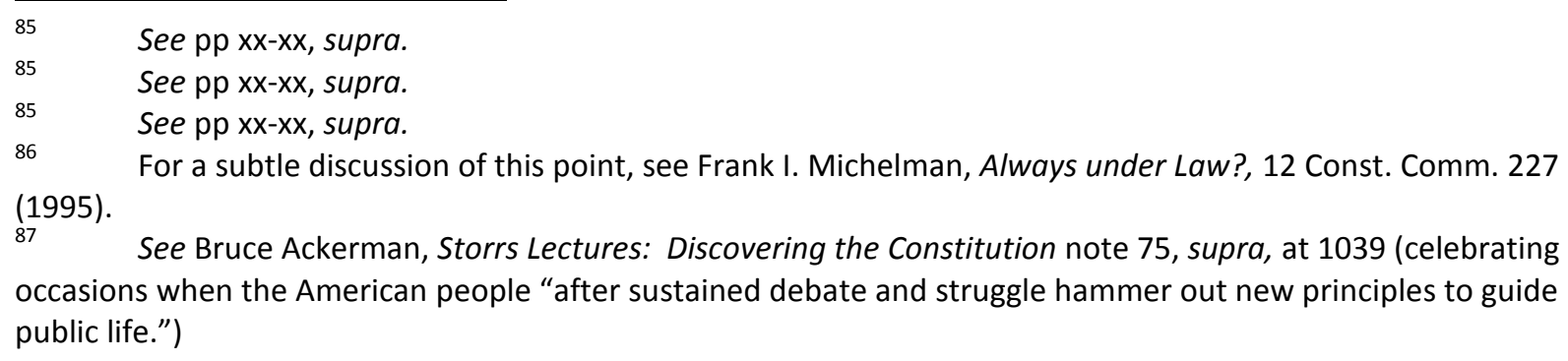
occasions when the American people "after sustained debate and struggle hammer out new principles to guide public life.") 
courts were relatively powerless. ${ }^{88}$ These arrangements were justified by belief in republican governance and the sort of free-form constitutionalism described above. On this view, politics was something more than a spectator sport. Direct and regular involvement in the institutions of government built civic virtue and contributed to the good life. ${ }^{89}$

There can be no doubt that one of the aims of the Constitutional Convention was to change this state of affairs. On the specific level, the Constitution's framers and supporters were deeply frightened by the threats to property and contract posed by state governments. On the more general level, they disparaged direct popular rule and believed that democracy led inevitably to faction and denial of minority rights. ${ }^{90}$

In one sense, this argument was not so much about constitutionalism as about the kind of constitution the United States should have. As noted above, most Antifederalists did not think of themselves as opposed to constitutional governance. They opposed only the Philadelphia Constitution precisely because it provided insufficient constitutional guarantees for local, popular democracy. But in a paradoxical and deeper sense, the Antifederalist critique of the Philadelphia Constitution meshed seamlessly with a complaint about constitutionalism in general. Because all formal and written constitutions channel politics and constrain the range of possible outcomes, they are all enemies of the sort of freeform, participatory democracy that some Antifederalists favored. If one truly believes in republican deliberation - in the ability of the people to transcend their differences and engage in selfrule - then fixed constitutional commands that predetermine outcomes and control politics are an evil. It is not accident, then, that the Constitution's defenders doubted the ability of average citizens to engage in direct deliberation and that its opponents feared that its ratification would presage a return

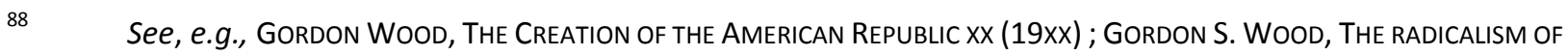
THE AMERICAN REVOLUTION 187-89 (1991).

89 See Gordon Wood, The Creation of the American Repubolc 615 (19xx).

90 The classic statement of this position is in Federalist No. 10 (Madison) in THE FEDERALIST: THE GIDEON EDITION, note 32 , supra, at 42 . 
to aristocratic governance. Nor is it a coincidence that James Madison, the Constitution's principal author, opposed easy constitutional revision and thought that constitutional creation should be limited to "great and extraordinary occasions," ${ }^{91}$ while Thomas Jefferson, a supporter of the Constitution who was nonetheless much more sympathetic to Antifederalist thought, believed that constitutions should last for only a generation. ${ }^{92}$

Finally, Antifederalist opposition inevitably raised vexing questions of constitutional authority. If, as the Antifederalists insisted, the new Constitution was not only illegal but also substantively evil, why should anyone feel obligated to obey its commands? Put differently, if there is a gap between the Constitution and the demands of substantive justice, why should we give precedence to the Constitution? Remarkably, this question seems to have remained mostly unasked in the period immediately following ratification. ${ }^{93}$ As we shall see, however, the question reemerged with a vengeance as various factions seized upon the Constitution to advance arguments and causes strongly opposed by others.

2. The Federalists. The Federalists supported the new Constitution and, of course, by extension, constitutionalism as well. Their writing therefore seems an unlikely place to look for constitutional skepticism, and indeed the tracts they produced contained detailed defenses of the new Constitution. Once again, though, another, competing story emerges if one looks beneath the surface. For example, on careful reading, The Federalist Papers, doubtless the most sophisticated defense of the Constitution, contain important seeds of constitutional doubt.

This doubt finds its clearest expression in Madison's and Hamilton's dismissal of what they called "parchment barriers." ${ }^{94}$ Hamilton justified the refusal of the framers to provide for a bill of rights

\footnotetext{
$91 \quad$ Federalist No. 49 in THE Federalist, note 32, supra, at 261.

92 See "Thomas Jefferson to James Madison, September 6, 1789, with Copies and Fragment," in VI THE WORKS OF ThOMAS JefFerson 3 (PAUl LeICESTER FORD, ED. 1904). See generally pp xx-xx, infra.

93 See notes $12-14$, supra.

$94 \quad$ See notes 32 \& 33, supra.
} 
partially on the ground that mere textual guarantees were worthless. ${ }^{95}$ In a letter to Jefferson during the ratification struggle, Madison seemed to agree. Experience with state constitutions demonstrated that "repeated violations of these parchment barriers have been committed by overbearing majorities." 96

In the Federalist Papers, Madison extended this argument and made it central to his defense of the Constitution more generally. Because men were not angels, he insisted, they were unlikely to respect limits on their power simply because of legal commands. Instead, these limits had to be bolstered by self-interest. This could be achieved, Madison insisted, by setting ambition against ambition and building conflict between self-interested actors into the structure of government. ${ }^{97}$

This classic argument in favor of the American Constitution also serves as the starting point for a skeptical critique. The argument suggests that constitutions are either ineffective or unnecessary. Government officials who are public spirited enough to obey constitutional commands will also be public spirited enough not to use their power to oppress others. In a world where men are angels, constitutions are unnecessary. The source of concern is about government officials who are not angels and who will be tempted to misuse their power. But officials of this sort will also be tempted to disobey constitutional commands. They will not be restrained by mere "parchment barriers," and, so, for them, the constitution will be ineffective. ${ }^{98}$

95 Hamilton made the point with reference to the failure of the Constitution to protect liberty of the press:

What is the liberty of the press? Who can give it any definition which would not leave the utmost latitude for evasion? I hold that be impracticable; and from this I infer, that its security, whatever fine declarations may be inserted in any constitution respecting it, must altogether depend on public opinion, and on the general spirit of the people and of the government. And here, after all, as intimated upon another occasion, must we seek for the only sold basis of our rights."

Federalist No. 84 in THE FederALIST, note 32, supra, at 446.

96 Letter from James Madison to Thomas Jefferson (Oct. 17, 1788), in 11 THE PAPERS OF JAMES MADISON 295, 297-99 (Charles F. Hobson \& Robert A. Rutland eds., 1977).

$97 \quad$ Federalist No. 51, in THE FEDERALIST note 32, supra, at 267-272.

98 See generally, Daryl Levinson, Parchment and Politics: The Positive Puzzle of Constitutional Commitment, 124 HaRV. L. REV . 657 (2011). 
In Federalist 78, Hamilton argued that this problem might be remedied by an independent judiciary with authority to invalidate unconstitutional acts. ${ }^{99}$ The argument is the source of an enduring puzzle. The judiciary had to be independent, Hamilton argued, if it was to resist pressure from the other branches of government and from the public to trample on constitutional rights. ${ }^{100}$ But unless we are to suppose that judges are angels, this very independence meant that these judges would be free to defy rather than enforce the Constitution. As an anonymous Antifederalist using the pseudonym Brutus wrote, a powerful judiciary lodged power "in the hands of men independent of the people, and of their representatives, ... [ [with] no way ... left to controul them." 101

Hamilton's response to this worry was to point out that a judiciary with "no influence over the sword or the purse" and possessed of "neither FORCE nor WILL," was "the least dangerous branch." 102 But at best this observation demonstrates only that judges acting alone would not themselves threaten liberty. It does not explain why they might not form a coalition with another branch to do so, how they could enforce the Constitution when they had neither force nor will, or what motive they would have to attempt such enforcement.

Madison's effort to deal with the problem of enforcement was at once more sophisticated and more skeptical. ${ }^{103}$ Instead of trusting any particular institution or group of people to act in a public spirited fashion, he argued for structural protections. The Constitution's byzantine system of overlapping and conflicting powers provided built-in mechanisms to discipline official misconduct. On his view, officials responsible to different constituencies and elected at different times will have

\footnotetext{
$99 \quad$ Federalist 78 in THE FEDERALIST, note 32, supra, at 401-408.

$100 \quad$ Id., at 403

101 The Complete Anti-Federalist at 2.9.196 (Herbert J. Storing, ed., 1981). See generally Shlomo Slonim, Federalist No. 78 and Brutus' Neglected Thesis on Judicial Supremacy, 23 Const. CoMm. 7 (2006). $102 \quad$ Federalist 78 in THE FEDERALIST, note 32, supra, at 402.

103 Madison might be read as rejecting an independent judiciary as a solution to the problem when he writes that "creating a will in the community independent of the majority, that is, of the society itself . . is but a precarious security; because a power independent of the society may as well espouse the unjust views of the major, as the rightful interests of the minor party, and may possibly be turned against both parties." Federalist No 51 in id, at 270.
} 
different interests. These interests will inevitably conflict with each other and provide an incentive for different branches of government to check each other. In this fashion, "the private interest of every individual [would] be the sentinel over the public rights"104 and the Constitution would become selfenforcing.

Madison's theory has been strongly criticized on a variety of grounds, but for our purposes, the important point is that it is in serious tension with the usual arguments for constitutionalism. First, notice that the theory says nothing about direct constitutional protection for individual rights, about judicial review, or about the enforcement of the legal minutiae contained in all constitutions. Madison's point is that the broad structures of the American Constitution will protect public rights, not that enforcement of specific commands is either possible or necessary. Put differently, his argument has nothing to do with, for example, the constitutionalization of issues about affirmative action, gay rights, abortion, or racial discrimination. Nor does it speak to enforcement of specific constitutional commands about questions like when the President's term of office begins or what the line of succession should be in the case of presidential death or incapacity. In short, it has nothing to do with the principal role that the Constitution plays in contemporary American life.

Of course, modern constitutional issues occasionally arise about the general structure of government. But here, too, Madison's argument is at best ambivalent about the role of constitutional text. A common modern argument for constitutional obedience rest on the value of stability and predictability. ${ }^{105}$ But Madison argued for a fluid, ill-defined government structure that would invite contestation between the branches and, so, counteract ambition with ambition. ${ }^{106}$

Finally, Madison never successfully resolved the "parchment barriers" problem. This phrase first appears in Federalist 48, which starts with the observation that "powers properly belonging to one of

\footnotetext{
$104 \quad$ Id., at 269.

105 See, e.g., Larry Alexander \& Frederick Schauer, On Extrajudicial Constitutional Interpretation, 110 HARV. L. REV. 1359 (1997).

106 Federalist 51 in THE FEDERALIST, note 32, supra at 268.
} 
the departments ought not be directly and completely administered by either of the other departments." ${ }^{107}$ Madison then turns to the question of how to enforce this requirement. Recall that James Iredell, reflecting the standard defense of constitutionalism a decade later, claimed that the Constitution "define[d] with precision the objects of the legislative power, and [restrained] its exercise within marked and settled boundaries." ${ }^{108}$ Remarkably, Madison used almost identical language to reject this ambition. "Will it be sufficient to mark, with precision, the boundaries of these departments, in the constitution of the government, and to trust to these parchment barriers against the encroaching spirit of power?"109 he asked. His response was a resounding "no." "This is the security which appears to have been principally relied on by the compilers of most of the American constitutions. But experience assures us, that the efficacy of the provision has been greatly overrated."110

Madison then proceeded to provide numerous contemporary examples of the failure of constitutional law to constrain the evils he identifies. The next several Papers address other inadequate mechanisms of enforcement, including constitutional amendment and popular democracy. ${ }^{111}$ Finally, in Federalist 51, he asked the question again and purported to provide an answer:

To what expedient then shall we finally resort, for maintaining in practice the necessary partition of power among the several departments, as laid down in the constitution? The only answer that can be given is, that as all the exterior provisions are found to be inadequate, the defect must be supplied, by so contriving the interior structure of the government, as that its several constituent parts may, by their mutual relations, be the means of keeping each other in their proper place. ${ }^{112}$

This "answer" is more than a little puzzling. Madison started out by saying that the new government with its structure of overlapping powers will protect liberty and the public interest. He recognized that these good outcomes were dependent upon this structure remaining intact and asked

Federalist No. 48 in id., at 256.

See note 76, supra.

Federalist No. 48 in Federalist, note 32, supra, at 256.

Id.

See Federalist Nos. 48-50 in id., at 256-264.

Federalist No. 51 in id, at 267. 
how the structural rules could be enforced. But his answer leads to a circle: The structural provisions, he says, will be enforced by the structural provisions.

The failure of this answer, offered by the most sophisticated constitutional thinker of his generation, is itself evidence in favor of constitutional skepticism. It points to the unavoidable fact that ultimately constitutional limits depend for their efficacy on the willingness of powerful, self -interested actors to exercise restraint. The doubt that they will do so remains with us still.

But even if we focus on the parts of Madison's argument that were more successful, his writings provide powerful arguments against conventional constitutionalism. It is worth emphasizing that Madison was deeply skeptical of text as a source of constraint, believed in fostering conflicts between the branches of government rather than using the Constitution to demarcate clear limits, and, at least at the time of the framing, thought that direct constitutional protection for civil liberties was unnecessary and unwise. ${ }^{113}$

Some historians have overestimated the influence of the Federalist Papers on contemporary debate. There is no reason to believe that they reflected views of most Americans or even of most of the Constitution's drafters. ${ }^{114}$ Madison and his co-authors are more important because of how they are viewed today than because of their influence at the time of the framing. For better or worse, the Federalist Papers have become a central part of our constitutional narrative. For purposes of this project, it matters that they are part of our counter-narrative as well.

3. The Bill of Rights. On conventional accounts, the most important, defining attribute of American constitutionalism is the textual protection and judicial enforcement of individual rights. According to these accounts, the American Bill of Rights is widely admired and copied throughout the world and symbolizes limited government and individual freedom. It is central to the story that constitutionalists tell about the American experiment.

113 See pp xx-xx, supra.

114 See Larry D. Kramer, Madison's Audience, 112 HARV. L. REV. 611 (1999). 
There are many reasons to doubt these accounts. In fact, many modern constitutions depart substantially from the American Bill of Rights model, in particular by providing for positive as well as negative rights. ${ }^{115}$ Moreover, many contemporary constitutional scholars have shown that judicial enforcement of Bill of Rights protections did little to preserve civil liberties when they were challenged in times of crisis. ${ }^{116}$ It has been less widely noted, however, that the writing and adoption of the Bill of Rights also support a more skeptical account of our constitutional history.

As already noted, the original Constitution contained no Bill of Rights and many of the framers thought that textual protection for civil liberties was either unwise or unnecessary, or both. The people who wanted a Bill of Rights were not the authors of the Constitution, but their opponents. ${ }^{117}$ Moreover, even the opponents tended to favor a Bill of Rights that applied only to the federal government. For most Antifederalists, a bill of rights was a means to limit federal power and, therefore, to leave the states free to protect or restrict the rights as they choose. ${ }^{118}$ This conception is far removed from the modern idea of textual protection for the individual against all of government.

The battle for ratification was closely contested, and some Federalists - most prominently, James Madison -- promised promptly to amend the Constitution once it had been adopted. ${ }^{119}$ Historians disagree about whether Madison authentically changed his mind and came to favor such

115 See, e.g., Mark Tushnet, State Action, Social Welfare Rights, and the Judicial Role: Some Comparative Observations, 3 CHI. J. INT. L. 435 (2002).

116 See, e.g., Michael Klarman, Rethinking the Civil Rights and Civil Liberties Revolutions, 82 U. VA. L. REV. 1 (1996); Gerald N. Rosenberg, The Hollow Hope: Can Courts Bring about Social Change (1991). Cf. Geoffrey R. Stone, Perilous Times: Free Speech in Wartime from the Sedition Act of 1789 to the War on Terror (2004).

117 See WOOdY HOLTON, UNRULY AMERICANS, note 2, supra, at 253 ("It is a remarkable but rarely noted irony that Americans owe their most cherished rights . . . not to the authors of the Constitution but to its inveterate enemies.")

118 See, e.g., Kurt T. Lash, The Original Meaning of an Omission: The Tenth Amendment, Popular Sovereignty, and "Expressly" delegated Power, 83 Notre DAME L. ReV. 1889, 1915-18 (2008); Akhil Amar, The Bill of Rights and the Fourteenth Amendment, 101 YALE L. J. 1193, 1202 (1992). The point is most obvious with regard to the establishment clause of the first amendment which, far from guaranteeing religious freedom, was understood to protect state establishments against federal interference. See, e.g., Kurt T. Lash, The Second Adoption of the Establishment Clause, 27 ARIZ . ST. L J. 1085, 1091-92 (1995). Cf. School Dist. of Abington Tp. v. Schempp, 374 U.S. 203, 255 (1963) (Brennan, J., concurring).

119 See Richard Labunski, Madison ANd the Struggle for the BILl of Rights 159 (2006);Robert Allen RutLAND, The BIRTH OF THE BILL OF RIGHTS, 1776-1791, at 171-73 (1955). 
amendments or whether his sponsorship of them was motivated solely by political the political necessity of winning reelection to Congress and persuading North Carolina and Rhode Island to join the union. ${ }^{120}$ Whatever his personal motives, though, it is clear that the amendments he proposed made no one happy.

Madison himself apparently doubted the efficacy of a bill of rights. Only months earlier, he had written to Jefferson that "experience proves the inefficacy of a bill of rights on those occasions when its controul is most needed."121 The Federalists who dominated the new Congress were even more skeptical. Madison was repeatedly frustrated in his efforts to get the House of Representatives even to consider the amendments. Members thought that they had more important matters to attend to. ${ }^{122}$ When debate finally started, many voiced strong opposition ${ }^{123}$ and, ultimately, adopted the provisions only grudgingly. ${ }^{124}$

One might suppose that passage of the provisions therefore amounted to a victory for the Antifederalists. In fact, though, many Antifederalists felt betrayed by the proposals that Madison advanced and that Congress adopted. ${ }^{125}$ They had hoped that that the Constitution would be revised so as to more clearly limit federal power in general. In particular, they favored provisions that would have

120 See PAUlene MAIER, RATIficAtion, note 2, supra, at 446 (quoting Madison's letter to Jefferson just before start of first Congress stating that he favored bill of rights "to extinguish opposition [to the Constitution] or at least break the force of it, by detaching the deluded opponents from their designing leaders.") Cf. WOODY HOLTON, UNRULY AMERICANS, note 2, supra, at 257 (noting that Madison "probably could not have been reelected" had he reneged on his promise to introduce a bill of rights, but that the energy he "brought to the fight for the Bill of Rights indicated that he had developed a deep personal commitment to the cause.")

121 I THE Republic OF LeTters: THE CORRESPONDENCE BETWEen THOMAS JefFERSON AND JAMES MADISON, 1776-1826 at 588 (James Morton Smith, ed. 1995) .

122 Many federalist congressmen, including Jackson, Sherman, White, Vining, Goodhue, and Livermore objected to even discussion a bill of rights until Congress has accomplished what they thought of as more important tasks. See I Annals of Congress 439-65 (Joseph GAles ed., 1834); The AMerican Republic: Primary Sources 446-51 (BRuChe Frohnen ED., 2002).

123 For example, James Jackson of Georgia argued that a bill of rights "[i]f not dangerous or improper, . . . is at least unnecessary." 1 ANNALS OF CONGRESS 459-60. John Vining of Delaware complained about the "uncertainty with which we must decide on questions of amendment, founded merely on speculative theory." Id., at 447. 124 For an account, see PAULENE MAIER, RATIFICATION, note 2, supra, at 455.

125 For example, Congressman Burke claimed that rather than "those solid and substantial amendments which the people expect, the proposals were "whip-syllabub" a dessert that was "forthy and full of wind, formed only to please the palate, or "like a tub thrown out to a whale" that sailors used to divert the whale from attacking a ship. Quoted in id., at 452. 
limited federal taxing power, banned a federal standing army, and made clear that there were no implied federal powers. What they got instead was nothing at all with regard to taxes, a pale, indirect, and ineffective reference to standing armies in the second and third amendments, and a plainly inadequate tenth amendment that, far from limiting implied powers, seemed to invite them. ${ }^{126}$

The tenth amendment was especially galling. The analogous provision in the Articles of Confederation had limited the federal government to powers expressly granted. Tellingly, Madison's proposal left out the word "expressly." Congressman Thomas Tucker tried to remedy this alleged defect by inserting this word, ${ }^{127}$ but, Madison opposed the change on the ground that it was "impossible to confine a Government to the exercise of express powers; there must necessarily be admitted power by implication." ${ }^{128}$ Tucker's amendment was defeated. ${ }^{129}$ The upshot was language and legislative history that could easily be read to expand rather than restrict federal power.

Thus, neither side attached much significance to the Bill of Rights. Instead, both sides seem to have had doubts about the importance or efficacy of textual protection for individual rights - doubts reinforced by what happened in the years following ratification of the amendments. Although antebellum the Court invalidated more federal statutes than commonly supposed, ${ }^{130}$ it did not use the Bill of Rights to invalidate a major piece of legislation until over half a century after ratification of the Bill of Rights, when it decided the infamous Dred Scott case. ${ }^{131}$ The Court did not invalidate a statute under the free speech clause of the first amendment until $1965 .{ }^{132}$

\footnotetext{
126 For examples of Antifederalist disappointment, see note 11, supra.

127 I ANNALS OF CONGRESS, note 123, supra, at 790.

$128 \quad$ Id.

129 See id.

$130 \quad$ See Keith E. Whittington, Judicial Review of Congress before the Civil War, 97 GEO. L. J. 1257 (2009); Mark Graber, Naked Land Transfers and American Constitutional Development, 53 VAND. L. REV. 73,75 (2000). $131 \quad$ Dred Scott v. Sandford, 60 U.S. (19 How.) 393 (1857). 132 See "Acts of Congress Held Unconstitutional in Whole or in Part by the Supreme Court of the United States," http://www.gpo.gov/fdsys/pkg/GPO-CONAN-2002/pdf/GPO-CONAN-2002-10.pdf. The first case was Lamont v. Postmaster General, 381 U.S. 301 (1965). As early as 1943, the Court narrowly construed a federal statute so as to avoid free speech difficulties. See Schneiderman v. United States, 320 U.S. 118, 133 (1943) ("because of our firmly rooted tradition of freedom of belief, we certainly will not presume in construing the
} 
Controversy surrounding the ninth amendment further illustrates the skepticism of the founding generation. The amendment provides "The enumeration in the Constitution, of certain rights, shall not be construed to deny or disparage others retained by the people." Although the meaning of the Amendment remains obscure and disputed, the history behind it is clear. In the run up to ratification of the Constitution, some Federalists answered the demand for a bill of rights with the argument that the specification of rights would inevitably be incomplete and might imply that the rights not specified were unprotected. ${ }^{133}$ When Madison introduced the Bill of Rights in the House he acknowledged that ' $[\mathrm{t}] \mathrm{his}$ was one of the most plausible arguments I have ever heard against the admission of a bill of rights" but observed that It "might be guarded against" by enactment of the ninth amendment. ${ }^{134}$

Commentators have disagreed about the precise meaning of the ninth amendment. ${ }^{135}$ There is no need to rehearse that dispute here. For present purposes, the key point is that on all interpretations, the amendment reflected widespread skepticism that a written constitution could sufficiently constrain government power. Importantly, the amendment guards against the disparagement of other rights that is, rights other than those specified in the Constitution. What, precisely, were these other rights? No doubt, people in the founding generation had opinions about what they were, but the ninth amendment amounts to a concession that it was impossible to reduce these opinions to constitutional text. Put differently, the ninth amendment embodies skepticism that any constitutional document can fully capture the norms that should govern a society. It is an express disavowal of Justice Iredell's

naturalization and denaturalization acts that Congress meant to circumscribe liberty of political thought by general phrases in those statutes.")

133 See, e.g., Federalist No. 84 (Hamilton) in THE FEDERALIST, note 32, supra, at 445-46.

$134 \quad$ I ANNALS OF CONGRESS at 456.

135 Compare, e.g., Randy E. Barnett, Reconceiving the Ninth Amendment, 74 CORNELL L. REV. 1 (1988)

(individual rights view) with Kurt T. Lash, The Lost Original Meaning of the Ninth Amendment, 83 TEX. L. REV. 331 (2004) (federalism view). For my own view, see Louis Michael Seidman, Our Unsettled Ninth Amendment, 98 CAL. L. REV. 2129 (2010). 
ambition to write a Constitution that "define[d] with precision the objects of the legislative power, and [restrained] its exercise within marked and settled boundaries." ${ }^{136}$

3. The Special Case of Thomas Jefferson. Although Thomas Jefferson was not in Philadelphia and did not participate directly in either the ratification struggle or the adoption of the Bill of Rights, ${ }^{137}$ he occupies iconic status in the standard story of American constitutionalism. According to that story, Jefferson was a "strict constructionist" who strongly supported constitutional restrictions on federal power and constitutional protections for individual rights. As he once wrote, "Our peculiar security is in possession of a written Constitution. Let us not make it a blank paper by construction." ${ }^{138}$ Jefferson's unsuccessful opposition on constitutional grounds to the creation of a national bank while in the Washington Administration, ${ }^{139}$ his secret authorship of the Kentucky Resolutions opposing the Alien and Sedition Acts while vice-president, ${ }^{140}$ his principled refusal to endorse internal improvements without a constitutional amendment, ${ }^{141}$ and his life-long devotion to religious liberty ${ }^{142}$ all contribute his image as a fastidious constitutionalist.

This story is not false. Jefferson was a strict constructionist, a believer in limited government and individual rights, and a defender of constitutional fidelity. But Jefferson was also an immensely complicated figure. Never a particularly systematic thinker, his writings and career are full of contradictions and ambiguities that have puzzled and enraged historians ever since. As Joseph Ellis aptly characterizes him, he has become "the enigmatic and elusive touchstone for the most cherished

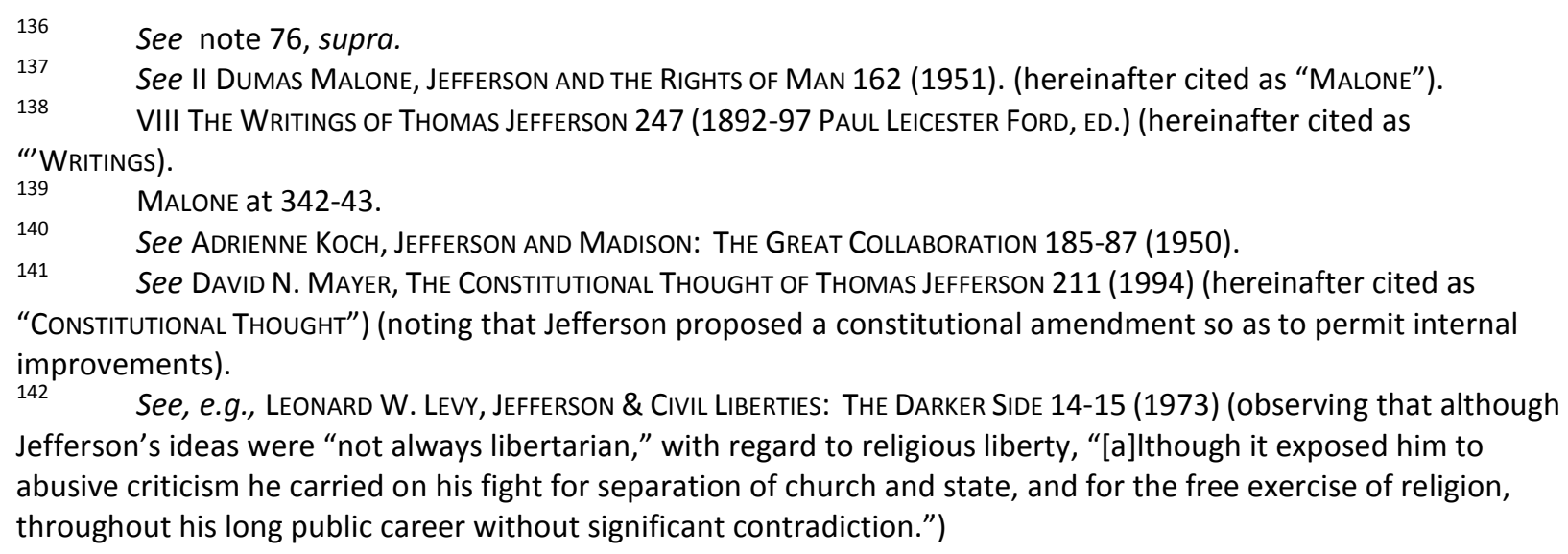


convictions and contested truths in American culture," and "the Great Sphinx of American history." ${ }^{143}$ It is therefore not surprising that there is another side to Jefferson's constitutional thought, much less often recognized and virtually never celebrated: Throughout his life, Jefferson was a constitutional skeptic.

This skepticism took a variety of forms. First, and most dramatically, Jefferson denied the legitimate power of the authors of constitutions to bind the future. His first statement of this view seems to have been in a letter to his friend, Madison shortly after the Constitution was ratified. There, he defended the principle that "'the earth belongs in usufruct to the living' that the dead have neither powers nor rights over it." 144 From this "self-evident" ${ }^{145}$ proposition, Jefferson derived his theory of generational limits on constitutional obligation. On his view, "by the law of nature, one generation is to another as one independent nation is to another." ${ }^{146}$ It followed that

[Members of the living generation] are masters ... of their own persons, and consequently may govern them as they please. But persons and property make the sum of objects of government. The constitution and the laws of their predecessors extinguished then in their natural course with those who gave them being. This could preserve their being till it ceased to be itself, and no longer. ... Every constitution, then, and every law, naturally expires at the end of 19 years. If it be enforced longer, this is an act of force, and not of right. ${ }^{147}$

Jefferson seems to have held these views throughout his life. After retirement, in a famous letter to Samuel Kercheval, Jefferson proposed amendments to the Virginia Constitution, including a built-in nineteen year expiration date, which, he argued, corresponded to the life-span of a single generation. He again insisted on the right of "each generation ... to choose for itself the form of government it believes most promotive of its own happiness; consequently, to accommodate to the

\footnotetext{
143 Joseph J. Ellis, American SphinX: The Character of Thomas Jefferson 10 (1996).

144 "Thomas Jefferson to James Madison, September 6, 1789, with Copies and Fragment," in VI THE WORKS OF ThOMAS JefFerson 3 (PAul LeICESTER Ford, ED. 1904).

145 Id.

$146 \quad$ Id.

$147 \quad$ Id.
} 
circumstances in which it finds itself, that received from its predecessors." ${ }^{148}$ Eight years later, and only two years before his death, he wrote to John Cartwright that "a generation may bind itself as long as its majority continues in life; when that has disappeared, another majority is in place, holds all the rights and powers their predecessors once held, and may change their laws and institutions to suit themselves. ... Nothing then is unchangeable but the inherent and unalienable rights of man." ${ }^{149}$

Second, Jefferson was deeply skeptical of judicial power in particular and of any authoritative, hierarchical system of constitutional enforcement in general. Jefferson's hatred of John Marshall and his anger at the Marshall Court's assertion of judicial power in Marbury v. Madison ${ }^{150}$ are well known. ${ }^{151}$ Early in his career, he seems to have been a supporter of judicial review, ${ }^{152}$ but his experience with a Federalist-dominated judiciary was enough to convince him that federal judges were a "corps of sappers and miners constantly working under ground to undermine the foundations of our confederated fabric" 153 and that an independent federal judiciary was "a solecism, at least in a republican government." ${ }^{154}$ At times, Jefferson suggested that there should be no federal judiciary at all. ${ }^{155}$

Part of Jefferson's skepticism about federal courts was grounded in his opposition to what he perceived as the nationalizing agenda of the federal judiciary. But the skepticism was also grounded in a more theoretical opposition to granting any single branch of government authoritative power to enforce the Constitution. The modern label given to Jefferson's position is "departmentalist" - that is the view that each department of government had equal right to interpret and enforce the Constitution. ${ }^{156}$ For

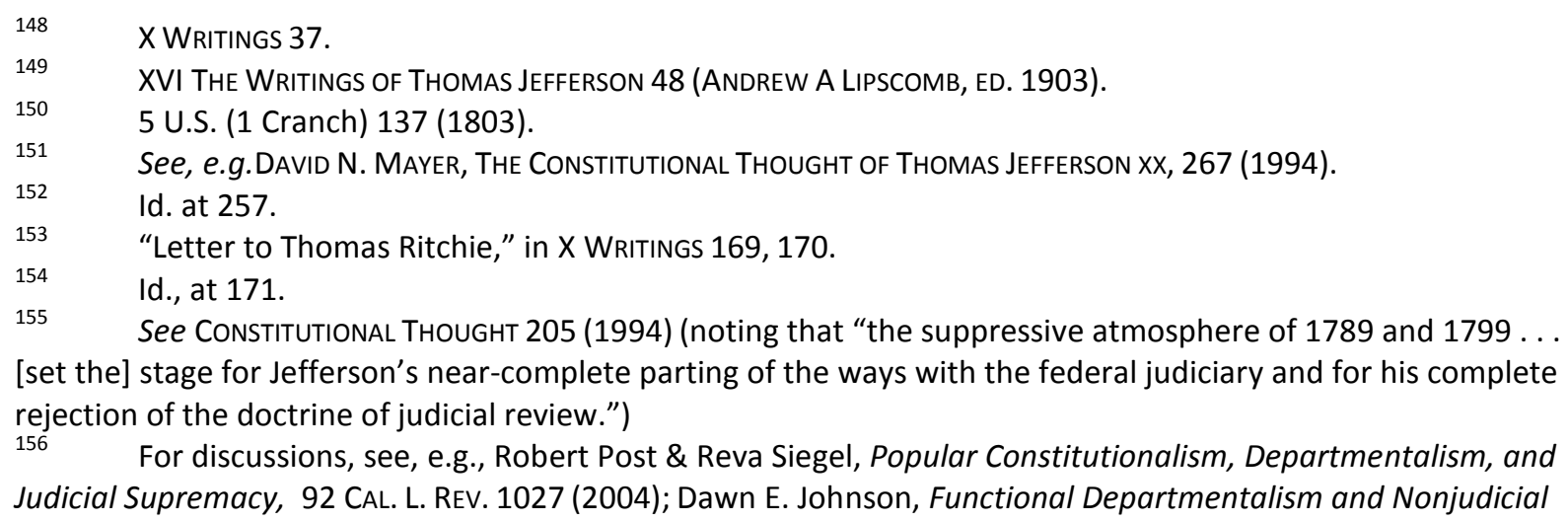


example, Jefferson believed that he had independent authority to determine that the Alien and Sedition

Acts were unconstitutional when exercising his pardoning power. In an explanation originally to be

delivered to Congress, but ultimately deleted for political reasons he wrote

Our country has thought proper to distribute the powers of its government among three equal \& independent authorities, constituting each a check on one or both of the others, in all attempts to impair its constitution. To make each an effectual check, it must have a right in cases which arise within the line of its proper functions, where, equally with others, it acts in the last resort \& its own judgment, \& uncontrouled by the opinion of any other department. We have accordingly, in more than one instance seen the opinions of different departments in opposition to each other, $\&$ no ill ensure. ${ }^{157}$

Later, in a letter to Abigail Adams justifying the pardons, he wrote

The judges, believing the law constitutional, had a right to pass a sentence of fine and imprisonment, because that power was placed in their hands by the constitution. But the Executive, believing the law to be unconstitutional, was bound to remit the execution of it; because that power has been confided to him by the constitution. That instrument meant that its co-ordinate branches should be checks on each other. But the opinion which gives to the judges the right to decide what laws are constitutional, and what not, not only for themselves in their own sphere of action, but for the legislature and executive also in their spheres, would make the judiciary a despotic branch. ${ }^{158}$

Today, many might accept the right of a President utilize his own constitutional judgment when exercising the pardon power, ${ }^{159}$ but Jefferson's devotion to decentralized constitutional authority extended well beyond this claim. While serving as Vice-President in the Adams Administration, he secretly authored the Kentucky Resolutions in protest against the Alien and Sedition Acts. ${ }^{160}$

Interpretation: Who Determines Constitutional Meaning?, 67 LAW \& ConTEMP. ProBS. 105 (2004); Michael Stokes Paulsen, The Most Dangerous Branch: Executive Power to Say what the Law Is, 83 GEO. L. J. 217 (1994).

$157 \quad$ Quoted in CONSTITUTIONAL THOUght 270.

$158 \quad$ Quoted in IV MALONE 155.

159 See, e.g., Abner S. Greene, Interpretive Schizophrenia: How Congressional Standing Can Solve the Enforce-but-not-Defend Problem, 81 FORD. L. REV. 577, 580 (arguing that President may interpret Constitution when exercising pardon power, but may not disobey court orders); Dawn E. Johnson, Functional Departmentalism and Nonjudicial Interpretation: Who Determines Constitutional Meaning, supra n. 20, at 110 (noting that "relatively few judicial supremicists would content that Presidents invariably must deter to Supreme Court interpretations with which they disagree - for example, in exercising the veto and pardon powers.") But cf. Harold J. Krent, Conditioning the President's Conditional Pardon Power, 89 CALIF. L. REV. 1665 (2001) (arguing that there should be judicial review of conditions imposed on pardons).

160 See note 140, supra. 
As originally drafted by Jefferson, the Eighth Resolution stated that each state had independent authority to determine whether the Constitution had been violated and what the remedy should be. In a case where the federal government assumed unconstitutional powers, "a nullification of the act is the rightful remedy." This was so because states had a "natural right . . . in cases not within the compact . . . to nullify of their own authority all assumptions of power by others within their limits."161

The resolution ultimately adopted by the Kentucky legislature omitted the incendiary "nullification" language. ${ }^{162}$ The parallel Virginia Resolutions, authored by Madison, was also more temperate. ${ }^{163}$ But when these less radical proposals failed to generate much northern support, Jefferson proposed a still more extreme remedy. In a letter to Madison, he urged the dissenting states to threaten "to sever ourselves from the union we so much value, rather than give up the rights of selfgovernment which we have reserved, \& in which alone we see liberty, safety \& happiness."164

There is a sense in which Jefferson's radical views about interpretive authority stemmed from his devotion to constitutional fidelity. Jefferson's allegiance was to the Constitution itself, not to mistaken interpretations of the Constitution advanced by misguided judges or legislators. From this perspective, it is modern believers in judicial supremacy who are unfaithful to the Constitution when they confuse mistaken Supreme Court interpretations of the Constitution with the Constitution itself.

In another sense, though, Jefferson's views are in deep tension with our standard constitutional story. That story rests crucially on the conflation of Supreme Court decisions with constitutional commands. Without an authoritative interpreter, "marked and settled boundaries" become impossible.

\footnotetext{
$161 \quad$ VII WRITINGS 301.

162 CONSTITUTIONAL THOUght 207

163 For a discussion of changes in the language of the Virginia Resolutions making them less radical, see Adrienne Koch, Jefferson and Madison: The Great Collaboration 190-91 (1950).

164 Jefferson's letter to Madison advocating this course of action is reproduced in id., at 196-97.
} 
Instead of providing a settlement, constitutionalism becomes a site for conflict and dissension of the sort that marked the pre-Revolutionary period. ${ }^{165}$

Of course, decentralized constitutional authority still requires all actors to remain loyal to their own, good faith understandings of constitutional limits. But not even this much can be said of the third branch of Jefferson's constitutional skepticism. It turns out that Jefferson also believed that, under appropriate circumstances, the Constitution, even as he himself understood it, should be disobeyed. Jefferson's clearest statement of this belief came in a famous letter to John B. Colvin written two years after the end of his presidency.

A strict observance of the written laws is doubtless one of the high duties of a good citizen, but it is not the highest. The laws of necessity, of self-preservation, of saving our country when in danger, are of higher obligation. To lose our country by a scrupulous adherence to written law, would be to lose the law itself, with life, liberty, property and all those who are enjoying them with us; thus absurdly sacrificing the end to the means. ${ }^{166}$

From this abstract statement, one might think that Jefferson believed in constitutional

disobedience only in extreme circumstances when the very survival of the state depended upon it. But Jefferson then went on to provide a "hypothetical case" suggesting that the Constitution might appropriately be violated in far less dire circumstances:

Suppose it had been made known to the Executive of the Union in the autumn of 1805, that we might have the Floridas for a reasonable sum, that that sum had not indeed been so appropriated by law, but that Congress were to meet within three weeks, and might appropriate it on the first or second day of their session. Ought he, for so great an advantage to his country, to have risked himself by transcending the law and making the purchase? The public advantage offered, in this supposed case, was indeed immense; but a reverence for law, and the probability that the advantage might still be legally accomplished by a delay of only three weeks were powerful reasons against hazarding the act. But suppose it was foreseen that a John Randolph would find means to protract the proceeding on it by Congress until the ensuing spring, by which time new circumstances would change the mind of the other party. Ought the Executive, in that case, and with that foreknowledge, to have secured the good to his country and to have trusted to their justice for the transgression of the law? I think he ought and that the act would have been approved. ${ }^{167}$

165 This point has been made repeatedly by modern opponents of departmentalism. See, e.g., Larry Alexander \& Frederick Schauer, On Extrajudicial Constitutional Interpretation, 110 HARV. L. REV. 1359 (1997).

$166 \quad$ XII WRITINGS 418.

167 Id. at 419-20. 
Two points are worth noting about this hypothetical. First, the acquisition of "the Floridas," while no doubt important, hardly rises to the level of "saving our country when in danger." Second, the hypothetical suggests that Jefferson thought it appropriate to disregard Congress's constitutional powers not just when it was impractical to consult with Congress, but also when opposition within Congress ("a John Randolph" - his cousin, incidentally ${ }^{168}$ ) would frustrate his goals. Taken together, these points suggest that Jefferson was much more ready to disregard constitutional obligation than his general language about necessity and self-preservation suggests.

Jefferson presents this problem as if it were merely hypothetical, but in fact his administration was marked by significant decisions that, by his own lights, violated the Constitution. We can put to one side his imposition of an embargo on foreign trade. Many others thought that the embargo was unconstitutional, ${ }^{169}$ but there is no evidence that Jefferson himself doubted its constitutional validity. The same cannot be said, however, for the Louisiana Purchase, perhaps the most consequential act of self-conscious constitutional disobedience in our history.

Early on in the negotiations with France over the vast Louisiana Territory, Jefferson seems to have agreed with his attorney general and secretary of the treasury that "there is no constitutional difficulty as to the acquisition of territory," ${ }^{170}$ although he appears to have thought a constitutional amendment wise before any of the territory was granted statehood. ${ }^{171}$ But as negotiations proceeded, he began to have doubts. In one private letter, he wrote that "Our confederation is certainly confined to the limits established by the revolution. ... The general government has no powers but such as the

\footnotetext{
168 On Jefferson's complicated relationship with his cousin, see See ALF J. MAPP, JR., THOMAS JEFFERSON: PASSIONATE PILGRIM 41-42 (1991).

169 See, Jefferson H. Powell, The Political Grammar of Early Constitutional LaW, 71 N.C. L. ReV. 949,994 (1993)

(noting Federalists' constitutional objections to the embargo).

170 See VIII WRITINGS 241 n.1.

171 See id.
} 
constitution has given it; and it has not given it a power of holding foreign territory, and still less of incorporating it into the Union. An amendment to the Constitution seems necessary for this" 172

Gradually, these doubts seem to have hardened into conviction. Jefferson wrote to a close friend that "I cannot help believing the intention was to permit Congress to admit into the union new states, which should be formed out of territory for which \& under whose authority alone they were acting. I do not believe it was meant that they might receive England, Ireland, Holland, \&c. into it." ${ }^{173}$ Accordingly, Jefferson began drafting proposed constitutional amendments to legalize the acquisition.

It soon became apparent, however, that constitutional scruples might prevent consummation of the purchase. Both France and Spain looked like they might back out of the deal, and haste in ratifying it became imperative. ${ }^{174}$ Faced with this difficulty, Jefferson concluded that "the less that is said about my constitutional difficulty, the better; and ... it will be desirable for Congress to do what is necessary in silence." ${ }^{175}$ The proposed amendments were dropped, and Jefferson went forward with the transaction despite his own constitutional objections.

Although Jefferson himself believed his actions were unconstitutional, few contemporaries shared his doubts. ${ }^{176}$ In contrast, a second, albeit less consequential, action taken by Jefferson was unquestionably unconstitutional. When the British attacked an American ship in 1807, Jefferson ordered the purchase of material to build gun boats without prior congressional authorization in clear violation of Article I, section 9, clause 7 of the Constitution, which prohibits withdrawing money from the treasury without "Appropriations made by Law." ${ }^{177}$ Only after the purchase did Jefferson ask for and receive congressional approval, albeit over the heated objections of the aforementioned John Randolph,

\footnotetext{
$172 \quad$ Id., at 262.

173 Id., at 247.

174 See David N. MAyer, The Constitutional Thought of Thomas Jefferson 250 (1994).

$175 \quad$ Id.

176 See IV Dumas Malone, JefFerson the PRESIDENT: FirSt Term, 1801-1805 at 320 (1970) (noting that "few other people appear to have expressed similar qualms before Congress met").

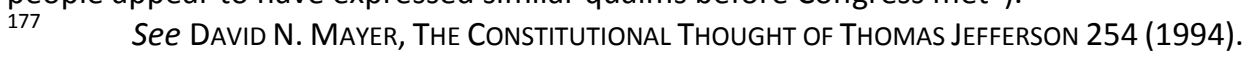


who complained that the President had violated his constitutional obligations. ${ }^{178}$ In his letter to Colvin five years later, Jefferson was unrepentant:

After the affair of the Chesapeake, we thought war a very possible result. Our magazines were illy provided with some necessary articles, nor had any appropriations been made for their purchase. We ventured, however, to provide them, and to place our country in safety; and stating the case to Congress, they sanctioned the act. ${ }^{179}$

How are we to reconcile Thomas Jefferson, the believer in limited government, strict

constructionist, and defender of constitutional purism with Thomas Jefferson, the constitutional skeptic unwilling to accept the binding force of the Constitution on future generations and ready to disregard limits on his power when he viewed it necessary to do so? Jefferson had a long career and doubtless changed his mind about some things. Not all his writings were fully thought out or grew out of deep, theoretical reflection. Like all politicians, he sometimes sacrificed his more general convictions to the necessities imposed by specific events. Ironically, his constitutional fastidiousness also contributed to his propensity to disregard constitutional limits. Few of Jefferson's contemporaries thought that there was a conflict between the Louisiana Purchase and constitutional commands. It was only because Jefferson read the Constitution so narrowly that he had to face the hard choice about whether to violate it.

But one cannot study Jefferson's career and writings without suspecting a deeper source for his ambivalence. Jefferson's own career captured the contradiction at the core of constitutional origins. Jefferson was, after all, the principal author of the Declaration of Independence. He was responsible for revolutionary defiance of legal authority in 1776, but, when he was elected President of the United States in 1801, he became the embodiment of legal authority. How could a reflective person who assumed both these roles possibly escape contradiction?

Id.

XII WRITINGS AT 419-20. 
One side of that contradiction - the side that prized constitutional obedience and celebrated constitutional restraint - is central to the mainstream story about constitutionalism's triumph. But Thomas Jefferson also had another side- a side that chafed at authority, abhorred stasis, and privileged deep moral convictions over positive law. That side, too, deserves attention and respect.

\section{Nullification, Concurrent Majorities, Secession, and the Civil War}

On standard accounts, southern secessionism led to the greatest threat to constitutional governance in our history. Southern radicals effectively seized control of almost half the country and mounted a treasonous war for human bondage and against the rule of law. The North responded by fighting to preserve the Union, and its victory constituted a decisive repudiation of doctrines like interposition, nullification, and a right of secession, which threatened the Constitution.

In this section, I intend to complicate this account. Elements of southern secessionist thought did raise important doubts about constitutional obligation, and many in the North did think of themselves as fighting to preserve the Constitution. But drawing the battle lines in this simple way misses the irony and paradox embedded in the arguments on both sides. On the one hand, the case for nullification was grounded in constitutional obligation. Even secessionists often insisted that their position was based on respect for, rather than defiance of, the Constitution. On the other hand, many northern abolitionists flirted with secession and constitutional disobedience, and, when war finally came, Lincoln himself at least arguably privileged preservation of union and termination of slavery over strict constitutional obligation.

The more interesting point, though, is that both northern and southern argument blurred the line between constitutional fidelity and defiance. The strength of our constitutional tradition forced both sides to cloak their stance in constitutional rhetoric, but sometimes the rhetoric did the work of justifying revolutionary insubordination. Just as Jefferson was torn between his commitment to the Declaration of Independence and to the Constitution, so, too, northerners and southerners alike 
unselfconsciously mixed together the language of natural right and revolution with the language of legal obligation and constitutional precommitment.

1. John C. Calhoun, and the theory of concurrent majorities. John C. Calhoun, the most important and sophisticated theoretician of Southern resistance, developed elaborate arguments supporting the power of states as against federal authority. ${ }^{180}$ Today, many commentators have marginalized Calhoun. On their view, his political position is ineradicably tainted by his support for slavery, and his theoretical position was decisively defeated in the Civil War. In particular, his support for nullification - the view that states could "nullify" federal decisions that violated the Constitution -and the theory of concurrent majorities - the view that legal legitimacy required majority approval by subnational units -- are treated as amounting to an antiquated and discredited rejection of constitutional supremacy. ${ }^{181}$

There can be no doubt that Calhoun spent much of his career justifying an economic and social system built on totalitarian suppression, and it is deeply wrong to insulate his theoretical musings from the purpose to which he put them. Still, the standard view radically oversimplifies Calhoun's theories, and, by extension, the complicated interplay of constitutionalism and constitutional skepticism that provided the intellectual backdrop for the Civil War.

180 For classic critiques of Calhoun's thought that nonetheless recognize his importance, see RICHARD Hofstader, THe American Political TRAdition AND the Men Who MAde IT (1973) (Calhoun "set forth a system of social analysis that is worthy of considerable respect"); LOUIS HARTZ, THE LIBERAL TRADITION IN AMERICA:AN INTERPRETATION OF AMERICAN Political THOUGHT SINCE THE ReVOLUTION (1991) 158-59 (conceding that Calhoun is "the philosophic darling of students of American political thought" but claiming that he was "a profoundly disintegrated political theorist"). See also RICHARD CURRENT, JOHN C. CALHOUN 128 (1963) ("In helping . . . to make Jefferson the light of illiberalism, Calhoun left his most important mark upon the development of American political thought"). For a sympathetic account of Calhoun's thought, see H. Lee Cheek, JR. , Calmoun and Popular Rule: The Political Theory of the DISQUISITION AND DISCOURSE (2001).

181 See id., at ix (noting that "most observers attempt to minimize the philosophical significance of [Calhoun's] work by arguing that [he] was merely a champion of sectional interests or that his ideas were antiquated even during his lifetime.") 
To understand the complexity, we need to separate out three aspects of Calhoun's thought: his position on constitutional obedience, his position on the Constitution's meaning, and his position on the appropriate means of constitutional enforcement.

With regard to the first question, Calhoun unambiguously and consistently presented himself as a constitutionalist. His argument in both the Disquisition and the Discourse, his two most important theoretical works, ${ }^{182}$ is shot through with assertions about the importance of constitutional governance as a means of controlling what Calhoun thought were dangerous tendencies toward individual willfulness that, in turn, translated into government tyranny. ${ }^{183}$

Of course, support for constitutional obedience leaves open the question of what, precisely, the Constitution commands. Calhoun's position on the Constitution's meaning was deeply rooted in a communitarian model of politics, which he associated with the sovereignty of individual states. He thought that political identity was inextricably wrapped up in community identity, which gave meaning to and appropriately constrained individual impulses. ${ }^{184}$

The importance of community leads to resistance to centralized power that has the potential to override community autonomy. Calhoun therefore favored a political system marked by what modern political scientists call "veto gates," but that Calhoun referred to as a requirement of "concurrent majorities." ${ }^{185}$ On this view, an overall majority throughout the polity is insufficient to justify impositions on minority communities. Instead, there must be concurrent majorities in each affected community.

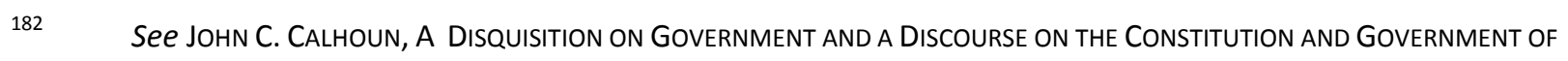
the United States (Richard K. Cralle, ed. 1851).

183 See, e.g., id., at 11 ("without a constitution - something to counteract the strong tendency of government to disorder and abuse, and to give stability to political institutions, -- there can be little progress or permanent improvement."), 81 (discussing how constitutional federalism avoids tyranny).

184 For a discussion of the communitarian strand in Calhoun's thought, see H. LEE CHEEK, CALHOUN AND POPULAR RULE, note 180, supra, at 90-92.

185 See JOHn C. CALHOUn, A Disquisition on Government AND A DisCourse ON THE CONSTITUTION AND GOVERNMENT OF THE UNITED STATES, note 182, supra, at 28. 
Calhoun's substantive theory has an obvious connection to standard Madisonian republicanism. Like Madison, he thought that majority faction could be controlled by dividing power and requiring the approval of different institutions responsible to different constituencies. ${ }^{186}$ He nonetheless departed from Madison in rejecting the claim that a large, geographically extended republic provided the best protection against faction. Calhoun put more faith in the Antifederalist commitment to localism and state autonomy.

This leads us, finally, to the question of constitutional enforcement. Because the greatest threat of majority tyranny came from the central government, it followed that constitutional enforcement could not be left to federal agents. To maintain constitutional government, the states had legitimate power to nullify unconstitutional acts by the federal government at least temporarily until supporters of federal action could secure an amendment to the Constitution confirming their interpretation. ${ }^{187}$ Put differently, on Calhoun's view, it was the people willing to acquiesce supinely to federal usurpation who tolerated constitutional disobedience. True constitutionalism required state resistance to unconstitutional federal action.

Once all this is understood, it becomes clear that there is a sense in which Calhoun was not a constitutional skeptic at all. ${ }^{188}$ But his thought also demonstrates that there is no bright-line distinction between obedience and defiance and that skeptical impulses often lies buried within the rhetoric of obedience.

186 Cf. H. Lee Cheek, Calhoun ANd Popular Rule, note 180, supra, at 89-90 (noting that the Disquisition and the Federalist Papers both argued that popular rule must be restrained to avoid political excesses).

187 See See John C. CALHOUN, A DISQUISITION ON GOVERNMENT AND A DISCOURSE ON THE CONSTITUTION AND GOVERNMENT OF THE UNITED STATES, note 185, supra, at 279 ("the several States, as parties to the compact, [have the right] of interposing for the purpose of arresting, within their respective limits, an act of the federal government in violation of the Constitution .... Without such a right, all the others would be barren and useless abstractions.") $188 \quad$ As one of his academic defenders put it, "Though a majority within the South were ready to exclaim, 'A fig for the Constitution! When the scorpion's sting is probing us to the quick, shall we stop to chop logic?', yet Calhoun and a small group of his followers were willing to remain constitutional logic-choppers in order to attempt the restoration of the original power of a minority to enforce constitutional limitations." JESSE T. CARPENTER, THE SOUTH As A Conscious MinoRITy 1789-1861: A Study In Political Thought 135-36 (1930). 
The problem is produced by three, interlocking facts. First, constitutionalism has the potential to delegitimize as well as legitimize exercises of power. An insistence on constitutional obedience can be put to revolutionary purposes. Thus, for Calhoun, the Constitution, properly understood, provided grounding for southern resistance to northern power. Second, the Constitution's meaning is often contestable. Calhoun interpreted the Constitution in a certain way, but others had different, conflicting interpretations. Finally, constitutional construction is always influenced by the intersection of theoretical concerns on the one hand and political expediency on the other. For example, both Lincoln and Calhoun had ideas about tyranny, freedom, and minority rights that influenced the way in which they read the Constitution. Both were politicians who used constitutional argument instrumentally to advance their positions.

Taken together, these three points mean that there will often be an ambiguous line dividing constitutionalism from rebellion. Because the Constitution's meaning is contested and because it provides a platform from which one can attack current distributions of power, constitutional rhetoric can support destabilization as well as settlement. Thus, to northern ears Calhoun's constitutionalism sounded like rebellion because it was based upon what northerners thought was an egregious misreading of the Constitution. From this perspective, Calhoun's preferred method of enforcement state nullification - looked like a rejection of the supremacy clause of Article VI and outright defiance of legitimate constitutional authority. From the perspective of Calhoun and his supporters, these same arguments were thought to serve the cause of constitutional obedience rather than defiance.

Moreover, Calhoun himself contributed to the blurring of the line between constitutional fidelity and defiance. Calhoun's interpretation of vague and ambiguous language in the Constituion was influenced by his particular conception of natural rights. Given this inevitable overlap between constitutional interpretation and background theoretical assumptions, it was easy for him to combine a worked out theory of constitutional interpretation with an argument grounded in extra-constitutional 
political morality. ${ }^{189}$ The Constitution was worthy of support precisely because it embodied principles that would support constitutional resistance if constitutional meaning were different. ${ }^{190}$ There was therefore no contradiction in mixing the language of constitutional obedience with language that would support rebellion against an unjust constitution.

2. Secession. Calhoun died in $1850,{ }^{191}$ the year of the compromise that put off the Civil War for a decade and before secessionists seriously threatened the union. ${ }^{192}$ When the breakup finally came, there was no theoretician of his sophistication and ability to defend the South's actions. ${ }^{193}$ Nonetheless, the justificatory rhetoric of secession was marked by the same ambiguity and contradiction that was central to Calhoun's earlier work.

Southerners often justified their act of supreme defiance in overtly constitutional terms. ${ }^{194}$ For example, in a speech before Congress as the Fort Sumter crisis unfolded, Jefferson Davis proclaimed that "[w]e claim our rights under the constitution; we claim our rights reserved to the States; and we seek by no brute force to gain any advantage which the law and the Constitution do not give us." 195

Remarkably, a few months later in his inaugural speech as he assumed office as the Confederacy's first and only President, Davis again invoked the United States Constitution. "The Constitution formed by our fathers," he asserted "is that of these Confederate States." ${ }^{196}$ In Davis's view, calling secession a

\footnotetext{
189 [Cite to Disquisition]

190 Cf. RICHARD N. CURRENT, note 180, supra, at 102-05 (linking Calhoun's theory of government to his interpretation of the Constitution).

191 See John Niven, John C. CALhoun ANd the Price of Union, A biography 343 (1988).

192 See I William W. Freehling, The RoAd to Disunion: SECESSIONISTS At Bay XX (1991).

193 See RICHARD CURRENT, note 180, supra, at 131 ("No one took over Calhoun's following and carried it, intact, through the decade of his death").

194 See II William W. Freehling, The RoAd to Disunion: SeCESSIONISTS TRIUMPHANT, 1854-1861 at 346 (2007) (discussing secessionsts' reliance on constitutional argument). For a sympathetic recounting of the various constitutional arguments supporting secession, see JESSE T. CARPENTER, THE SOUTH AS A CONSCIOUS MINORITY 1789-1861: A Study in Political Thought 200-220 (1930).

195 "Remarks on the Special Message on Affairs in South Carolina. Jan. 10, 1861" in SOUTHERN PAMPHLETS ON SECESSION, NOVEMBER 1860-APRIL 1861 .at 118 (Jon L. Wakelyn ed. 1996).

196 At the PreCIPICE: Americans North ANd SOUth dURING THE SECESSION CRISIS 47 (2010) (quoting Davis).
} 
revolution was "an abuse of language." 197 Secession was, instead, an effort "to save ourselves from a revolution." ${ }^{198}$

Given this stance, it is no surprise that framers of the Confederate Constitution closely followed the text of the original United States Constitution ${ }^{199}$ For many southerners, disunion, like nullification, was a method of constitutional enforcement that, they hoped, would bring the north to its senses and lead to reunion on a sound constitutional footing. ${ }^{200}$ According to Davis, the collapse of union was not because of "the defect of the system," the mechanisms of which were "wonderful, surpassing that which the solar system furnishes for our contemplation." Rather, the collapse was caused by "the perversion of the Constitution," by, for example, efforts to suppress slavery in the territories and failure to enforce the Constitution's fugitive slave clause. The result, on his view, was the "substitution of theories of morals for principles of government." ${ }^{201}$

The fact that the attempt to dissolve the Constitution could itself be justified in constitutional terms illustrates just how slippery the distinction is between constitutionalism and its opposite. And indeed, southern rhetoric seamlessly integrated the language of revolutionary anticonstitutionalism with the language of constitutional fidelity. In the same speech in which Davis claimed "our rights under the Constitution," he also invoked the natural right of rebellion.

If I must have revolution, I say let it be a revolution such as our fathers made when they were denied their natural rights....

$197 \quad$ Id. at 39 (quoting Davis).

198 Id.

199 See Marshall L. DeRosa, The confederate Constitution of 1861 at 57 (1991) (confederate framers "merely cop[ied] the U.S. Constitution"); G. Edward White, Recovering the Legal History of the Confederacy, 68 WASH. \& LEE L. REV. 467, 496-97 (2011) (confederate drafters used U.S. Constitution as a template).

$200 \quad$ As Jefferson Davis put it in his inaugural address as President of the Confederacy, "it is not unreasonable to expect that States from which we have recently parted may seek to unite their fortunes to ours under the Government which we have instituted". Confederate States of America - Inaugural Address of the President of the Provisional Government, February 18, 1861, http://avalon.law.yale.edu/19th century/csa csainau.asp. See also SHEARER DAvis BowmAN, AT THE PRECIPICE: AMERICANS NORTH AND SOUTH DURING THE SECESSION CRISIS 151 (2010) (many southerners hoped for "a compromise and a reconciliation").

201 See "Remarks on the Special Message on Affairs in South Carolina. Supra note 195, at 135. 
Washington and Jackson ... are often presented as authority against [revolution] Washington who led the army of the Revolution; Washington, whose reputation rests upon the fact that with the sword he cut the cord which bound the Colonies to Great Britain . . . . Washington, who presided when the States seceded from the [Articles of] Confederation, and formed the union, in disregard of the claims of the States not agreeing to it; and Jackson, glorious old soldier, who, in his minority, upon the sacred soil of South Carolina, bled for the cause of revolution and the overthrow of a Government which he believed to be oppressive. ${ }^{202}$

Consider, as well, a remarkably sophisticated speech defending secession given by Judah P.

Benjamin, who went on to serve in the cabinet of the Confederacy. Benjamin effortlessly combined arguments grounded in constitutional obedience with arguments grounded in constitutional skepticism. Benjamin's argument begins with an echo of Jefferson's rejection of the ability of one generation to bind another:

$[T]$ he right of the people of one generation, in convention duly assembled, to alter the institutions bequeathed by their fathers is inherent, inalienable, not susceptible of restriction; . . . [B]y the same power under which one Legislature can repeal the act of a former Legislature,, so can one convention of the people duly assembled .... ${ }^{203}$

But Benjamin apparently saw no contradiction between assertion of this "inalienable" right to disregard the Constitution on the one hand and assertion of rights derived from the Constitution on the other.

[T] he President of the United States tells us that he does not admit [the right of secession] to be constitutional, that it is revolutionary. I have endeavored ... to show that [secession] ... grows out of the Constitution, and is not in violation of it. If I am asked how I will distinguish this from revolutionary abuse, the answer is prompt and easy. These States, parties to the compact, have a right to withdraw from it, by virtue of its own provisions are violated by the other parties to the compact .... [sic] $]^{204}$

Southern schizophrenia on the legal and moral justification for secession should come as no surprise. There is, after all, no necessary contradiction between an argument insisting that there is a constitutional right to secession and an argument insisting that there is a natural right to secession whether the Constitution authorizes it or not. Yet if there is not a contradiction, there is at least a tension between the two positions. If there is a natural right to ignore constitutional provisions when

$\begin{array}{ll}202 & \text { Id., at } 132 . \\ 203 & \text { Id. at } 103 . \\ 204 & \text { Id. at } 107 .\end{array}$


they invade rights, then, it would seem, there is a natural right to resist constitutionally protected secession if one thought that disunion invaded rights. ${ }^{205}$ This tension is built into the genetic material of a country founded on both the Declaration of Independence and the Constitution. It is the tension that has allowed both constitutionalism and constitutional skepticism to flourish throughout our history.

3. The North. The speeches and writings of Calhoun, Davis, and Benjamin are part of our constitutional tradition's anti-canon. They are marginalized, discredited, or ignored because, rightly or wrongly, they are thought to embody constitutional defiance. In contrast, the words of northern abolitionists and defenders of union are part of the canon. They are glorified because they are thought to embody the goodness and permanence of constitutional government. ${ }^{206}$ But just as it is too simple to characterize the South's defenders as anti-constitutionalists, so too northerners were not uniform and consistent defenders of constitutional obligation.

We can begin with the fact that, long before the Civil War, many northerners openly flirted with secession. According to one of his biographers, John Calhoun first learned of arguments favoring secession by listening to Timothy Dwight, the President of Yale College, who was reacting to Jefferson's election as President. ${ }^{207}$ Some leading Federalists went beyond talk and actually plotted to secede. ${ }^{208}$

205 Cf. RICHARD CURRENT, supra note 180, at 115 (noting tension in Calhoun's thought between desire to protect South Carolina nullifiers as minority in the country, but not pro-unionists in South Carolina as minority in the state).

206 On constitutional law's canon and anti-canon, see Jamel Greene, The Anticanon, 125 HARV. L. REV. 379 (2011); . J.M. Balkin \& Sanford Levinson, The Canons of Constitutional Law, 111 HARV. L. REV. 963 (1998); Richard A. Primus, Canon, Anti-Canon, and Judicial Dissent, 48 DUKE L. J. 243 (1998).

207 See Margaret L. Colt, John C. Calhoun 28 (1950).

208 See Kevin M. Gannon, Escaping “Mr. Jefferson's Plan of Destruction: New England Federalists and the Idea of a Northern Confederacy, 1804-1804, 21 JournAl Of THE EARLy Republic 413 (2001); DuMAS MALONE, JefFERSON the PRESIDENT: FirSt TeRM, 1801-1805 at 403-07 (1970).

For example, Timothy Pickering, who had served as Postmaster General, Secretary of War, and Secretary of State in the Washington and Adams administrations, wrote that secession

would be welcomed in Connecticut, and could we doubt of New Hampshire? But New York must be associated; and how is her concurrence to be obtained? She must be made the center of the confederacy. Vermont and New Jersey would follow of course, and Rhode Island of necessity. 
During the War of 1812, New England states took numerous measures to obstruct the war effort. Toward the end of the war, Massachusetts convened the Hartford Convention, attended by it and other New England states, to consider secession. ${ }^{209}$ Ultimately, the Convention stepped back from the precipice, but only after passing a resolution warning that if its demands were not met "it will be expedient for the legislatures of the several States to appoint delegates to another convention to meet at Boston, with such powers and instructions as the exigency of a crisis so momentous may require." ${ }^{210}$

As tensions surrounding slavery mounted, the same schizophrenia about constitutional obedience that dominated southern rhetoric also began to appear in the north. A few intrepid abolitionist lawyers like Lysander Spooner and Alvan Stewart argued in court that the Constitution limited slavery, although their arguments had no discernible effect. ${ }^{211}$ Even abolitionist judges rejected the arguments, but they, too wrapped themselves in constitutional obligation when they upheld the claims of southern slaveholders. On the other hand, more radical abolitionists embraced constitutional disobedience. William Lloyd Garrison chose Independence Day to publicly burn the Constitution and denounced it as a pact with the devil. ${ }^{212}$ Although he eventually changed his mind, Frederick Douglas originally argued that for northern secession from the southern states. ${ }^{213}$ On the eve of the Civil War, Wendell Philips argued that "dissolution of the Union, sure to result speedily in the abolition of slavery, would be a lesser evil than the slow faltering disease."214

\footnotetext{
Quoted in Edward Payson Powell, Nullification ANd SeCEssion In the United States: A History of Six AtTEMPTS DURING the First Century of the Republic 128-29 (2002).

209 See James M. Banner JR., To the Hartford Convention: The Federalists and the Origins of Party Politics in MASSACHUSETTS 1780-1815 (1970).

210 See EDWARD PAYSON POWELL, note 208 supra, at 238.

211 For an account, see Robert M. COVER, JUSTICE ACCUSED: ANTISLAVERY AND THE JUdICIAL PROCESS 154-58 (1975).

212 See Henry Mayer, All on Fire: William Lloyd Garrison ANd the Abolition of Slavery 445 (1998).

213 For an account of his original beliefs and his reasons for changing them, see FREDERICK DOUGLASS, MY BONDAGE AND MY FREEDOM 396 (1855) (CHECK] During the secession crisis of 1861, Douglass at least conditionally reembraced disunionism. See ERIC Foner, The FIERY Trial: ABraham LinColn ANd AMERICAN SLAVERY 146 (2010) (“If the Union can only be maintained by new concessions to the slaveholders, let the Union perish.")

$214 \quad$ Quoted in EDWARD PAYSON POWELL, note 208 supra at 351.
} 
Even mainstream political figures on occasion, embraced anti-constitutional language. During the debate over the Compromise of 1850, Senator William Seward, later Lincoln's secretary of state, argued that the "law of liberty" was a "higher law than the Constitution," and that this law would not be satisfied until the South, albeit "in your time and your own manner," yielded "to the progress of emancipation." ${ }^{215}$ Similarly, William Ellery Channing, the foremost Unitarian clergyman in the United States claimed that "A higher law than the Constitution protests against [the Fugitive Slave Act]. ${ }^{216}$

Both abolitionism and constitutional disobedience remained minority positions well into the Civil War, yet as conflict with the South intensified, willingness to stretch or ignore the Constitution increased as well. Many northerners participated in the effort to obstruct slaveholders who attempted to exercise their constitutional right to capture slaves who had fled to the north, and a courageous few participated in the "underground railroad" that led to freedom. ${ }^{217}$ There was talk of nullification, and one northern radical wrote that "we have got to come to Calhoun's ground." ${ }^{218}$ The Republican Party ran on a platform that promised a refusal to enforce the Dred Scott decision, and some state legislatures voted to nullify it. ${ }^{219}$ Although John Brown's violent and illegal raid was widely condemned even in the North, a handful of northerners treated Brown as a hero. ${ }^{220}$

4. The Special Case of Abraham Lincoln. On the spectrum of northern, Republican opinion, Lincoln was at best a moderate. A lifelong opponent of slavery, he nonetheless repeatedly promised not to interfere with it in states where it already existed. He acknowledged that southerners had the right to the return of escaped slaves and conceded that emancipation would have to be gradual and that

215 See Speech by William H. Seward on Freedom in the New Territories, U.S., Congress, Senate, Congressional Record, 31st Cong., 1st sess., appendix, 260-69.

216 Quoted in EDWARD PAYSON POWELL, , note 208 supra, at 351.

217 See DAVID M. POTTER, THE IMPENDING CRISIS, 1848-186 at 133-35 (1976).

218 Quoted in ERIC FOnER, THE FIERY TRIAL: ABRAHAM LINCOLN AND AMERICAN SLAVERY 134 (2010).

219 See Eric Foner, Free Soll, Free Labor, Free Men: The Ideology of the Republican Party before the Civil War 29229 (1995).

220 See James BreWer SteWart, Holy Warriors: The Abolitionists ANd AMERICAN SLAVery 169 (1997). 
slaveholders should be compensated for their loss. ${ }^{221}$ Although he appears to have changed his mind at the very end of his life, until then, he believed that free African Americans could not successfully live with whites, and repeatedly backed a variety of schemes that would lead to their departure from the United States. ${ }^{222}$

Moreover, throughout his adult life, Lincoln presented himself as a fervent believer in constitutionalism and a defender of constitutional government. As a young man, he first gained notoriety with his "Lyceum Address," which criticized "mob rule" and urged "every American ... [to] swear by the blood of the Revolution, never to violate in the least particular, the laws of the country; and never to tolerate their violation by others." ${ }^{223}$ Over two decades later, he began his campaign for the Republican nomination for President with his famous Cooper Union speech, where he made a remarkably lawyerly, constitutional argument against the result in Dred Scott. ${ }^{224}$ He justified the Emancipation Proclamation as a constitutional exercise of his war power to seize enemy property, and he stubbornly and scrupulously declined to extend it to areas where, in his judgment, emancipation lacked military, and therefore constitutional, justification. ${ }^{225}$

But Lincoln's constitutionalism, like Jefferson's, was ambivalent and contradictory. Exclusive focus on his belief in constitutional fidelity misses much of his complexity and greatness. Consider, first

221 See ERIC FONER, THE FIERY TRIAL, note 218, supra, at xviii, 57-58.

222 Even after signing the preliminary Emancipation Proclamation, Lincoln told African American leaders that [y]ou and we are different race. We have between us a broader difference than exists between almost any other two races. ... [T]his physical difference is a great disadvantage to us both, as I think your race suffers very greatly . . . by living among us, while ours suffer from your presence .... [O]n this broad continent, not a single man of your race is made equal of a single man of ours. ... It is better for us both, therefore to be separated.

V The COllected Works of Abraham Lincoln 371-72 (Roy P. BASLER ED., (1953). On Lincoln's change of heart at the end of his life, see ERIC FONER, THE FIERY TRIAL, supra note 218, at xx.

$223 \quad$ The Lyceum address is reproduced at http://www.abrahamlincolnonline.org/lincoln/speeches/lyceum.htm.

224 See The Address of the Hon. Abraham LinCON, in Indication of the Policy of the Framers of the Constitution AND THE PRINCIPLES OF THE REPUBLICAN PARTY (1860).

225 See louis P. MAsur, Lincoln's Hundred Days: The EMANCIPATION Proclamation ANd the WAR FOR the UNION 181 (2012). 
the Lyceum Address. There is no mistaking Lincoln's fervent support for constitutionalism and the rule of law. But just beneath the surface is the same tension that has bedeviled constitutionalism throughout our history. Could Lincoln have been completely unaware of the irony when he urged his fellow Americans to "swear by the blood of the Revolution" not to violate the law? And what are we to make of this remarkable passage, which, in light of subsequent events, has puzzled and fascinated Lincoln's many biographers. ${ }^{226}$ After praising the courage and fortitude of the founding generation, he added:

This field of glory is harvested, and the crop is already appropriated. But new reapers will arise, and they, too, will seek a field. It is to deny, what the history of the world tells us is true, to suppose that men of ambition and talents will not continue to spring up amongst us. And, when they do, they will as naturally seek the gratification of their ruling passion, as others have so done before them. The question then is, can that gratification be found in supporting and maintaining an edifice that has been erected by others? Most certainly it cannot. ... Towering genius distains a beaten path. ... It thirsts and burns for distinction; and, if possible, it will have it, whether at the expense of emancipating slaves, or enslaving freemen. ${ }^{227}$

Lincoln hastened to disown the subversive implications of this language. In the very next passage, he states that he does not admire "towering genius" of this sort. On the contrary, "it will require the people to be united with each other, attached to the government and laws, and generally intelligent, to successfully frustrate his designs." ${ }^{228}$ But in light of his subsequent career, it is hard to take this disclaimer at face value. Early in life, Lincoln set for himself the goal of achieving the very sort of glory that he describes. ${ }^{229}$ Can it really be that the Great Emancipator himself meant to unambiguously condemn a "towering genius" who overcame "the government and laws" by "emancipating slaves"?

The Cooper Union speech contains a similar ambiguity. Lincoln began the speech rhetorically asking "what is the frame of Government under which we live?" and responding that "The answer must

See, e.g., ERIC FONER, THE FIERY TRIAL, note 223, supra, at 27.

See note 88, supra.

Id.

See Doris Kearns Goodwin, Team of Rivals: The Political Genius of Abraham Lincoln xx (2005). 
be: 'The Constitution of the United States.'" It is constitutional obligation, he tells us, that "furnishes a precise and an agreed starting point for a discussion between Republicans and that wing of the Democracy headed by [his political opponent] Senator [Stephen] Douglas." 230

Lincoln then proceeded to make a detailed, persuasive, and legalistic argument that the federal government had constitutional power to prohibit slavery in the territories. He relied upon the standard tools of constitutional interpretation: the Constitution's language, the intent of the framers, and historical practice before and immediately after the Constitution was ratified. ${ }^{231}$ This is unquestionably the language of American constitutionalism.

But then, as the speech draws to a close, comes this:

If slavery is right, all words, acts, laws, and constitutions against it, are themselves wrong, and should be silenced, and swept away. If it is right, we cannot justly object to its nationality - its universality; if it is wrong, they cannot justly insist upon its extension - its enlargement. All they ask, we could readily grant, if we thought slavery right; all we ask, they could as readily grant, if they thought it wrong. They thinking it right, and our thinking it wrong, is the precise fact upon which depends the whole controversy. Thinking it right, as they do, they are not to blame for desiring its full recognition, as being right; but, thinking it wrong, as we do, can we yield to them? Can we cast our votes with their view, and against our own? In view of our moral, social, and political responsibilities, can we do this? ${ }^{232}$

Lincoln's answer is a resounding "no." The last lines of his speech are far removed from the claim that dry and disinterested constitutional analysis will or should resolve the dispute over slavery. Instead, he gave full throated endorsement to the primacy of moral obligation: "LET US HAVE FAITH THAT RIGHT MAKES MIGHT, AND IN THAT FAITH, LET US, TO THE END, DARE TO DO OUR DUTY AS WE UNDERSTAND IT." 233

It turns out, then, that even if, as Lincoln claimed, constitutional meaning is a "precise and agreed starting point for discussion," it is not the ending point. After all the legal argument is finished, it

See THe Address of the Honorable Abraham Lincoln, note 224, supra, at 5.

See id. at 6-18.

Id. at 31 .

Id. at 32 . 
is not the Constitution, but the moral status of slavery that is the "precise fact upon which depends the whole controversy."

The tension between Lincoln's commitment to constitutionalism and his commitment to extraconstitutional morality extended beyond his rhetoric. It marked his entire administration. Consider first the actions Lincoln took unilaterally immediately after assuming office. With Congress not in session and facing a military emergency, he suspended habeas corpus in particular areas. ${ }^{234}$ When a judge had the audacity to issue a writ requiring the release of an under-aged soldier who allegedly enlisted without the consent of his parents, the soldier's commander refused to comply and arrested the lawyer who served the writ. Not satisfied with even this result, Secretary of State Seward stopped payment on the judge's salary. ${ }^{235}$ A few months later, Chief Justice Taney issued a writ ordering the release of a Confederate supporter, John Merryman, and ruling that Lincoln had acted unconstitutionally by suspending the writ. ${ }^{236}$ Lincoln simply ignored the opinion. ${ }^{237}$

The Constitution specifically provides for the suspension of habeas corpus when in "Cases of Rebellion or Invasion the public Safety may require it," ${ }^{238}$ but many scholars think that the President may not exercise this authority without congressional authorization. ${ }^{239}$ Lincoln evidently disagreed, but the important point is that he thought he acted rightly even if he violated the Constitution. In his famous speech to Congress on July 4, 1861, he argued that the Framers intended to allow the executive

234 For the first order, see Abraham Lincoln, Executive Order to the Commanding General of the Army of the United States (Apr. 27, 1861), in 7 A COMPILATION OF THE MESSAGES AND PAPERS OF THE PRESIDENTS 3219 (James D. Richardson ed., 1917). For a discussion and citations to other orders, see David Barron \& Martin Lederman, The Commander in Chief at the Lowest Ebb - A Constitutional History, 121 HARV. L. ReV. 941, 998-1000 \& n. 210 (2008).

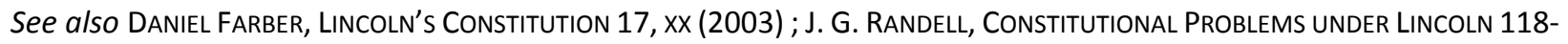
139 (1951).

$235 \quad$ [A Fiery Trial?]

236 See ex parte Merriman, 17 F. Cas. 144 (C.C.D. Md. 1861).

237 See J. C. RANDELL, CONStitutional PROBlems Under LINCOLN 161-62 (1951).

238 U. S. Const., Art. I, §9, cl. 2.

239 See, e.g., Amanda L. Tyler, Suspension as an Emergency Power, 118 YALE L. J. 600, 689 (2009); III JOSEPH StORY, COMmentaRIES ON THE CONSTITUTION OF THE UnITEd STATES 483 (Ronald D. Rotunda \& John E Nowack eds., 1987). For judicial authority, see Ex parte Bollman, 4 Cranch 75, 101, (1807); Hamdi v. Rumsfeld, 542 U.S. 507. 561-63 (2004) (Scalia, J., dissenting). 
to suspend the writ, at least when Congress was not in session. But he coupled this legal defense with the assertion that, even if his constitutional argument was incorrect, he had nonetheless done the right thing.

The whole of the laws which were required to be faithfully executed were being resisted and failing of execution in nearly one-third of the States. Must they be allowed to finally fail of execution, even had it been perfectly clear that by the use of the means necessary to their execution some single law, made in such extreme tenderness of the citizen's liberty that practically it relieves more of the guilty than of the innocent, should to a very limited extent be violated? To state the question more directly, are all the laws but one to go unexecuted and the Government itself go to pieces lest that one be violated? Even in such a case would not the official oath be broken if the Government should be overthrown, when it was believed that disregarding the single law would tend to preserve it? ${ }^{240}$

Suspension of habeas corpus was not the only constitutionally dubious action Lincoln took during the 1861 crisis. Like Jefferson before him, he spent unauthorized funds to raise troops, thereby violating not only Article I, §9, cl. 7, which prohibits expenditures except "in Consequence of Appropriations made by Law" but also Article I, $§ 7, \mathrm{cl}$. 12, which gives Congress the seemingly exclusive power to raise and support Armies.". ${ }^{241}$ In his July 4 speech, he did not even try to defend the legality of these expenditures. Instead he insisted that this action "whether strictly legal or not" was justified by "popular demand and a public necessity." ${ }^{242}$

Even this was not Lincoln's most egregious legal violation. In the immediate wake of the attack on Fort Sumter, he secretly ordered military officials to enter into private contracts for the supply of military equipment in violation of appropriations measures and existing law. Lincoln did not discuss these expenditures in his July 4 speech. They remained secret for months until Congress discovered them. ${ }^{243}$ At that point, Lincoln made no effort to defend the legality of what he had done. Instead, he

\footnotetext{
240 Abraham Lincoln, Special Session Message (July 4, 1861) in 7 A COMPILATION OF THE MESSAGES AND PAPERS OF THE PRESIDENTS 3221 (James D. Richardson ed., 1917).

241 For an account, see David Barron \& Martin Lederman, The Commander in Chief at the Lowest Ebb-A Constitutional History, note 234, supra, at 1001.

242 See note 240 , supra.

243 See David Barron \& Martin Lederman, The Commander in Chief at the Lowest Ebb - A Constitutional History, note 234, at 1001-1005.
} 
confessed that his actions were "without any authority of law," and acknowledged that he was responsible for "whatever error, wrong, or fault was committed." 244

Throughout the War, Lincoln authorized many other actions that were constitutionally dubious. For example, after former Congressman Clement Vallandigham gave a speech attacking pursuit of the War, he was arrested, tried, and incarcerated in seeming violation of his first amendment rights. A public outcry ensued, and Lincoln, unwilling to turn him into a martyr, responded by ordering Vallandigham's expulsion from the United States. ${ }^{245}$ At least Vallandigham had a trial. Thousands of other citizens were placed in executive detention without the benefit of trial. ${ }^{246}$

Most commentators treat these incidents as constitutionally justified but nonetheless regrettable at best, or as constitutional lapses perhaps excusable at worst. ${ }^{247}$ The Emancipation Proclamation is very different. No one today apologizes for it or treats it as a source of regret. It is universally celebrated and widely thought to be among a handful of the greatest decisions ever made by an American President. Accordingly, if the Proclamation counts as an example of constitutional disobedience, it transforms the narrative of American constitutionalism.

Does it so count? Any fair treatment of the Proclamation must acknowledge its ambiguous straddling of the border between the conflicting traditions of constitutional fidelity and constitutional skepticism. Defenders of constitutional fidelity can point to the fact that Lincoln himself never admitted that the Proclamation was unconstitutional. On the contrary, he strongly defended it as an appropriate exercise of his commander in chief power and, to the consternation of some of his more

\footnotetext{
$244 \quad$ Cong. Globe, $37^{\text {th }}$ Cong., 2d Sess. At 2383 (message from the President to the Senate and House).

245 For an account, see Geoffrey R. Stone, Perilous Times: Free SPEeCH in WARTIMe from the Sedition Act of 1789 TO THE WAR ON TERRORISM 98-120 (2004).

246 See [Foner]

247 For generally sympathetic accounts, see J. C. RANDELL, CONSTITUTIONAL PROBLEMS UNDER LINCOLN 161-62 (1951); DANiel Farber, Lincoln's Constitution (2003); Dennis J. HutChinson, LINCOlN the DictatoR 55 S.D. L. ReV. 284 (2010).
} 
radical allies, carefully cabined its geographical effect to locations where liberation advanced the war effort. $^{248}$

Despite these facts, there is strong reason to count the Proclamation as an important - perhaps the most important - act of constitutional disobedience in our history. The skeptical account of the Proclamation begins with the sheer audacity of what Lincoln did. As historian Richard Slotkin has written:

At the stroke of the pen some $\$ 3.5$ billion in property was legally annihilated - this at a time when national GDP was less than $\$ 4.5$ billion and national wealth (the total value of all property) was about $\$ 16$ billion. In purely economic terms, this was an expropriation of property on a scale approaching that of Henry VIII's seizures of church properties during the Reformation, exceeded only by the nationalization of factories and farms after the Bolshevik Revolution. ${ }^{249}$

Lincoln, together with almost everyone else in $\operatorname{mid}-19^{\text {th }}$ century America, thought that these property rights were constitutionally protected, and he said so repeatedly. In his most extensive speech on slavery before his election, delivered in Peoria in 1854, Lincoln denounced it as a "monstrous injustice," but nonetheless acknowledged that the Constitution protected the rights of slaveholders. Northerners were obligated to adhere to the constitutional bargain "not grudgingly, but fully, and fairly." The rendition of escaped slaves was "a dirty, disagreeable job," but because of the fugitive slave clause, Lincoln voiced support for "any legislation, for the reclaiming of their fugitives, which should not, in its stringency, be . . . likely to carry a free man into slavery." 250

Similarly, in his first inaugural address, Lincoln made clear that he lacked constitutional authority to interfere with slavery ${ }^{251}$ and stated that he had no objection to the Corwin Amendment, which would

248 See LOUIS P. MASUR, LINCOLN'S HUNDRED DAYS XX-XX (20XX).

249 Richard SLOtKIN, The Long Road to ANTIETAM: How the CIVIL WAR BeCAME A ReVolution Xx (2012).

250 See "Peoria Speech, October 16, 1854," available at http://www.nps.gov/liho/historyculture/peoriaspeech.htm.

251 Lincoln quoted from a previous speech where he had said that "I have no purpose, directly or indirectly, to interfere with the institution of slavery in the States where it exists. I believe I have no lawful right to do so, and I have no inclination to do so." Abraham Lincoln, "First Inaugural Address, March 4, 1861, available at http://www.bartleby.com/124/pres31.html. 
have permanently entrenched slavery. ${ }^{252}$ In his view, the Amendment did no more than restate slaveholder rights already implicit in the Constitution. ${ }^{253}$

Even after the Civil War began, Lincoln demonstrated marked reluctance to interfere with slavery. As late as 1862 he stated that "emancipation was a subject exclusively under the control of the states." ${ }^{254}$ He demonstrated little interest in enforcing the First Confiscation Act, ${ }^{255}$ which deprived slaveholders of their property right in slaves used to further the war effort. ${ }^{256}$ When General John Fremont declared martial law in Missouri and ordered emancipation of all slaves in the state as a means of weakening the enemy, Lincoln countermanded the order and then removed Fremont from command. $^{257}$

The strictly legal question, then, is whether military necessity and the President's commanderin-chief authority under Article II justified a massive, permanent, uncompensated destruction of private property and the negation of what Lincoln himself conceded would otherwise have been the constitutional rights of slaveholders. There are strong reasons to doubt that the military necessity argument can do this work. Indeed, Lincoln himself initially thought that it could not. In a letter to Senator Orville Browning after the Fremont episode, Lincoln wrote that Fremont's proclamation "is

252 The amendment provided:

No amendment shall be made to the Constitution which will authorize or give to Congress the power to abolish or interfere, within any State, with the domestic institutions thereof, including that of persons held to labor or service by the laws of said State.

"The Failed Amendments," available at http://www.usconstitution.net/constamfail.html.
${ }_{253}$

I understand a proposed amendment to the Constitution-which amendment, however, I have not seen-has passed Congress, to the effect that the Federal Government shall never interfere with the domestic institutions of the States, including that of persons held to service. To avoid misconstruction of what I have said, I depart from my purpose not to speak of particular amendments so far as to say that, holding such a provision to now be implied constitutional law, I have no objection to its being made express and irrevocable.

Abraham Lincoln, "The First Inaugural Address," note 251, supra.

Quoted in LOUIS P. MASUR, LINCOLN'S HUNDRED DAYS XX-XX (20XX).

Act of Aug 6, 1861, ch. 60, 12 Stat. 319.

See Silvana R. Siddali, From Property to Person: Slavery and the Confiscation Acts, 1861-1862 at 19 (2005).

LOUIS P. MASUR, LINCOLN'S HUNDRED DAYS XX-XX (20XX). 
purely political, and not within the range of military law, or necessity. ... Can it be pretended that it is any longer the government of the U.S. - any government of constitution and laws, -- wherein a General, or a President, may make permanent rules of property by proclamation?"258

Of course, it is possible that changes in military circumstances made emancipation necessary when the Proclamation was issued even though it was not when Freemont acted. But in fact, events occurring after Lincoln wrote this letter further weakened the military necessity argument. If military necessity were really the reason for emancipation, one would have supposed that Lincoln would have ordered it when the North was losing the war. Instead, Lincoln self-consciously delayed emancipation until the North won its first major victory on the battle field. ${ }^{259}$

Moreover, as noted above, the First Confiscation Act provided a mechanism to liberate slaves who were used to aid the Confederate war effort. The Second Confiscation Act went further and provided such a mechanism for slaves owned by disloyal individuals whether or not the slaves were used to fight the war. ${ }^{260}$ By the time of the Proclamation, then, the precise legal issue was whether there was a military necessity justifying the emancipation of slaves not already subject to manumission by the Confiscation Acts - that is, slaves not being used to fight the war and held by slaveholders who were loyal to the Union. It is hard to see how emancipation of these slaves served a significant military purpose. ${ }^{261}$

The fact that the emancipation was permanent poses another legal difficulty. The Preliminary Proclamation, which warned of impending emancipation if the South continued its revolt, declared that

\footnotetext{
258 Quoted in id, at xx.

259 See Richard Slotkin, The Long Road to Antietam: How the civil War BeCAMe A ReVolution Xx (2012).

260 See Act of July 17, 1862, ch. 195, 12 Stat. 589.

261 This is not to say that the Confiscation Acts were effective in freeing slaves. As the leading student of the Acts has written, they were "of dubious efficacy." Silvana R. Siddali, From Property to Person: SLAVERy and the CONFISCATION ACTS, 1861-1862 at 6 (2005). But the Emancipation Proclamation was similarly ineffective when first promulgated. The ultimate emancipation of African American slaves depended on the advance of Union armies, which neither the Acts nor the Proclamation could bring about.
} 
slaves would be "then, thenceforward, and forever free." 262 For reasons that are somewhat mysterious, the final Proclamation left out the word "forever," ${ }^{263}$ but Lincoln repeatedly and forcefully stated that he would not rescind the Proclamation even if southern states agreed to rejoin the union. ${ }^{264}$ Yet, ironically, before he issued the Proclamation, Lincoln himself explained why permanent freedom could not be justified by military necessity. In the Browning letter quoted above, he stated that

If a commanding general finds a necessity to seize the farm of a private owner ... he has the right to do so, and to so hold it as long as the necessity lasts; and this is within military law, because within military necessity. But to say the farm shall no longer belong to the owner or his heirs forever; and this as well when the farm is not needed for military purposes as when it is, is purely political, without the savor of military law about it. And the same is true of slaves. If the General needs them, he can seize them, and use them; but when the need is past, it is not for him to fix their permanent future conditions. ${ }^{265}$

For these reasons, the legal argument supporting the Emancipation Proclamation is quite vulnerable. Of course, clever lawyers can make and have made arguments on the other side, but focusing exclusively on the legal argument misses the crucial point. For purposes of constructing a historical tradition, what matters most is not the technical legality of the Proclamation, but its cultural meaning.

That meaning is directly linked to the fact that emancipation was not merely a military necessity. To see this point, compare the Proclamation to General William Tecumseh Sherman's widespread destruction and seizure of civilian property during his infamous march through Georgia in 1864. Perhaps the actions of Sherman's troops were justified by military necessity, but no one today celebrates those actions as an iconic moment in American history. The Emancipation Proclamation is celebrated precisely because people understood then and understand now that it was not merely a

262 See "Preliminary Emancipation Proclamation, September 22, 1862, available at http://www.archives.gov/exhibits/american_originals_iv/sections/transcript_preliminary_emancipation.html. 263 See "The Emancipation Proclamation, January 1, 1863" available at http://www.archives.gov/exhibits/featured_documents/emancipation_proclamation/transcript.html.

264 See ERIC Foner, THe FIERY TRIAL TRIAL: ABRAHAM LinColn AND AMERICAN SLAVERY XX (2010) 265 Quoted in id., at xx. 
military tool, the use of which was necessary but nonetheless to be regretted. Instead of advancing the North's war aims, the Proclamation changed those aims. A war that was fought to preserve the Constitution became a war to dismantle the constitutional structures that protected tyranny and oppression.

Both contemporary supporters and opponents of the Proclamation had no doubt that this was its true meaning. For example, the New York Herald, in an editorial opposing the Proclamation, warned that it would inaugurate a "social revolution." 266 The Springfield Republican, in an editorial supporting the Proclamation, came to a remarkably similar conclusion, declaring that that "by the courage and prudence of the President, the greatest social and political revolution of the age will be triumphantly carried through in the midst of civil war." ${ }^{267}$ In a letter home, a Union soldier wrote that "though the President carefully calls [the Proclamation] nothing but a war measure . . it is the beginning of a great reform and the first blow struck at the real, original cause of the war." ${ }^{268}$ Perhaps Karl Marx, then working as an American newspaper correspondent, put it best:

[Lincoln] sings the bavura aria of his part hesitatively, reluctantly, and unwillingly, as though apologizing for being compelled by circumstances "to act the lion." The most redoubtable decrees - which will always remain remarkable historical documents - flung by him at the enemy all look like, and are intended to look like, routine summonses sent by a lawyer to party. . .. His latest proclamation, which is drafted in the same style, the manifesto abolishing slavery, is the most important document in American history since the establishment of the Union, tantamount to the tearing up of the old American Constitution. ${ }^{269}$

Indeed, Lincoln himself acknowledged as much. Before the Proclamation, in his first inaugural address, he made clear that he had "no purpose, directly or indirectly, to interfere with the institution of slavery in the States where it exists. I believe I have no lawful right to do so, and I have no inclination to do so." If there should be war, he declared, the war would be fought to support the proposition that

Quoted in LOUIS P. MASUR, LINCOLN'S HUNDRED DAYS XX-XX (20XX).

Id., at $x x$.

Id., at $x x$.

Id., at $x x$. 
"the laws of the Union be faithfully executed in all the States" as the Constitution commanded. He added that he had no objection to a constitutional amendment "to the effect that the Federal Government shall never interfere with the domestic institutions of the States, including that of persons held to service." ${ }^{270}$

After the Proclamation, things were different. The purpose of the war was not to ensure that the laws be "faithfully executed in all the States," but to show that a nation "conceived in liberty and dedicated to the proposition that all men are created equal" could "long endure." Instead of acquiescing to a constitutional amendment that guaranteed the rights of slave holders, Lincoln promised "a new birth of freedom." 271 No longer content to merely stop the spread of slavery, he declared that "if God wills that [the war] continue until all the wealth piled by the bondsman's two hundred and fifty years of unrequited toil shall be sunk, and until every drop of blood drawn with the lash shall be paid by another drawn with the sword, as was said three thousand years ago, so still it must be said 'the judgments of the Lord are true and righteous altogether.'”272

It is nonetheless true that Lincoln also supported formal, constitutional change in the form of the thirteenth amendment, which legalized, regularized, and extended the Proclamation. Yet even the struggle over the formal amendment process can be incorporated into the skeptical narrative.

Opponents of the Thirteenth Amendment claimed that amendments contrary to the framers' original intent were illegitimate. ${ }^{273}$ Ultimately, proponents of the Amendment overcame this opposition and, with it, the view that all major provisions in the Constitution were sacred and permanent. ${ }^{274}$ Proponents successfully argued that the Constitution was flawed in important respects - a skeptical theme renewed

\footnotetext{
$270 \quad$ See notes 251-253, supra.

271 See "Gettysburg Address," at http://avalon.law.yale.edu/19th_century/gettyb.asp.

272 See "Second Inaugural Address of Abraham Lincoln," available at http://avalon.law.yale.edu/19th_century/lincoln2.asp.

273 See Michael Vorenberg, Final Freedom: The Civil War, The Abolition of Slavery, and the ThirTeenth AMENDMENT XX (20XX).

$274 \quad$ Id., at $x x$.
} 
by Justice Thurgood Marshall over a hundred years later when, writing on the bicentennial of the Constitution, he observed that he did not "find the wisdom, foresight, and sense of justice exhibited by the framers particularly profound. To the contrary, the government they devised was defective from the start." 275

More significantly, the thirteenth amendment itself would have been unthinkable but for the transformation in American political culture produced by the War, the Proclamation and the subsequent enlistment of two hundred thousand African American soldiers who fought gallantly on the Union side. African American chattel slavery is greatest injustice in our nation's history. For three quarters of a century, this injustice was protected by seemingly immutable constitutional text. When the injustice was finally rectified, the efficient cause of the change was not constitutional processes, which, on the contrary, made change seem impossible, but a bloody war that claimed over seven hundred thousand lives.

One hundred years later, this understanding of the Civil War and of the Proclamation remains vibrant. Virtually no one today celebrates the Proclamation as a military measure reluctantly embraced only because otherwise sacred constitutional rights had to be ignored so as to defeat the enemy. Instead, it symbolizes a constitutional transformation. As President Obama stated in his own proclamation celebrating the one hundred fiftieth anniversary of Lincoln's, "with that document, President Lincoln lent new moral force to the war by making it a fight not just to preserve, but also to empower. He sought to reunite our people not only in government, but also in freedom that knew no bounds of color or creed. Every battle became a battle for liberty itself. Every struggle became a struggle for equality." 276

275 Thurgood Marshall, Reflections on the Bicentennial of the United States Constitution, 101 HARV. L. REV. 1, 2 (1987).

276 "Presidential Proclamation, $150^{\text {th }}$ Anniversary of the Emancipation Proclamation," available at http://www.whitehouse.gov/the-press-office/2012/12/31/presidential-proclamation-150th-anniversaryemancipation-proclamation. 
Can there be any doubt, then, that the story of emancipation should occupy a central place in the historical narrative of constitutional skepticism?

\section{Constitutional Skepticism and the Progressive Movement}

Defenders of the Progressive movement associate it with the modernization and rationalization of government, protection of populations made vulnerable by industrialization, reform of the party system, and the beginnings of redistributionist legislation. ${ }^{277}$ Critics point to the racism of many Progressives, their disregard for civil liberties, and the fact that many Progressive "reforms" shielded entrenched interests from the discipline of market competition. ${ }^{278}$

Modern students of Progressivism on both sides of the debate are much less likely to emphasize the extent to which the movement offered a deep and biting challenge to American constitutionalism. Yet especially in its early years, constitutional skepticism played a central role in progressive practice and theory. Progressive politicians rallied popular support by railing against supposed constitutional restraints on regulatory legislation, and Progressive theorists over a range of disciplines developed important critiques of constitutionalism. ${ }^{279}$

1. Progressive Politics. With the possible exception of the original Antifederalists campaign, no political movement in American history attacked constitutionalism with as much gusto and persistence as the Progressives. The highpoint of the attack came in 1912, when Theodore Roosevelt ran for President on his fabled Bull Moose ticket. Roosevelt's constitutional radicalism alienated long-time Republican supporters like Henry Cabot Lodge and doomed his chance for the Republican nomination. ${ }^{280}$ Undeterred, he ran as a Progressive on a party platform that declared that "the people are the masters

277

278 See, e.g., Richard A. EPSTEIN, How PRogressives ReWrote the Constitution (2006).

279 See, e.g., William E. Forbath, Popular Constitutionalism in the Twentieth Century: Reflections on the Dark Side, the Progressive Constitutional Imagination, and the Enduring Role of Judicial Finality in Popular Understanding of Popular Self-Rule, 81 CHI,-KENT. LAW REV. 967, 974, 976 (2006) (arguing that "Progressives set out to rethink and remake the Constitution root and branch."); WILLIAM G. ROSS, A MUTED FURY: POPULISTS, PROGRESSIVES, AND LABOR UNIONS CONFRONT THE COURTS, 1890-1937 at 49 (1994)(noting progressive "impatience with all constitutional orthodoxies, including the Constitution itself.")

280 See id., at 138; William Forbath, note 279, supra, at 980. 
of the Constitution" and demanded "such restrictions on the courts as shall leave to the people legitimate authority to determine fundamental questions of social welfare and public policy." 281 Roosevelt himself was convinced that creating a modern government required the dismantling of separation of powers and of federalism. ${ }^{282}$ He proposed that "the people shall themselves have the right to say whether their representatives in the legislature and the executive office were right or whether their representatives on the Court were right." ${ }^{283}$ In a speech delivered in Columbus, Ohio, he argued that the American people must be "the masters and not the servants of even the highest court in the land" and "the final interpreters of the Constitution." Without this final authority "ours is not a popular government." ${ }^{284}$ Despite this sweeping rhetoric, Roosevelt limited his programmatic suggestions to the recall of state judicial decisions. But in a letter to fellow progressive Herbert Croly, he stated that "one way or the other, it will be absolutely necessary for the people themselves to take control of the interpretation of the constitution. Even in national matters this ought to be, and in my opinion will eventually be done." 285

Roosevelt was hardly alone in attacking standard versions of constitutionalism. Woodrow Wilson, who ran against Roosevelt in 1912, was much more restrained in his criticism, but Wilson had made his academic reputation years before with a book-length attack on the constitutional structure of the American government. ${ }^{286}$ In 1908 , he wrote that constitutional government "does not remain fixed in any unchanging form, but . . is altered with the change of the nation's needs and purposes." ${ }^{287}$

\footnotetext{
281 Quoted in LARry KRAmer, The PeOPLe ThemSELVES, note 63, supra, at 215.

282 See William Forbath, note 279, supra, at 977.

283 "Roosevelt Answers Cry of Revolution," N.Y. TIMES, Feb. 27, 1912, at 1, 3 quoted in Victoria Nourse, A Tale of Two Lochners: The Untold History of Substantive Due Process and the Idea of Fundamental Rights," 97 CAL. L. REV. 751, 774 (2009).

284 Theodore Roosevelt, A Charter of Democracy - Address before the Ohio Constitutional Convention at Columbus, Ohio, Feb. 21, 1912, in Social Justice ANd Popular Rule: EsSAYs, AddresSes, ANd Public Statements Relating to the Progressive Movement 143 (1926)

285 WiLlaM G. ROSS, A MUTED FURY, note 279, supra, at 144 \& n. 66.

286 WoOdroW WiLSON, CONGRESSIONAL GOVERNMENT: A STUdY IN AMERICAN Politics (1885).

287 WOODROW WILSON, CONSTITUTIONAL GOVERNMENT IN THE UNITED STATES 22 (1908).
} 
During the 1912 campaign, he joined Roosevelt in arguing that Article $V$ of the Constitution should be revised so as to make amendment much easier. ${ }^{288}$

Robert LaFollette, perhaps the most important Progressive in Congress, called for the election and recall of judges. He referred to judges who issued anti-labor decisions as "petty tyrants and arrogant despots." 289 The great social reformer, Jane Addams and Herbert Croly, the founding editor of the New Republic and the most widely read journalistic voice for Progressivism, both insisted that social reform could be accomplished only by dismantling constitutional obstacles. ${ }^{290}$ Croly was especially biting, repeatedly decrying "the monarchy of the law and the aristocracy of the robe." ${ }^{291}$ On two occasions, the young Felix Frankfurter wrote in the pages of Croly's magazine that the due process clauses of the Fifth and Fourteenth Amendments should be repealed. ${ }^{292}$ As William Forbath has pointed out, leading Progressives like John Dewey thought that constitutional rights "seemed destined to ossify into impediments to practical change" and were "exactly what the laissez-faire jurists insisted: a limit on democracy's capacity to reconstruct its social environment by redistributivist means." 293

2. Progressive Theory. No doubt, these attacks on judicial enforcement of the Constitution and on the Constitution itself were politically situated. Rightly or wrongly, Progressives believed that conservative judges stood in the way of reforms they thought best for the country. They therefore had compelling instrumental reasons delegitimize the basis of judicial power. Tellingly, when control over the judiciary shifted in the late 1930's, many Progressives changed their views.

Still, political motivations should not obscure the important contributions that Progressive intellectuals made to the ongoing debate about constitutionalism. These contributions included worked

288 See William Forbath, note 279, supra, at 978. Louis Brandeis, then the leading public interest lawyer in the United States, made a similar plea. Id.

289 See Walter F. Murphy, Congress AND the COURT 50 (1962)

$290 \quad$ William Forbath, note 279, supra, at 280.

291 Herbert Croly, Progressive Democracy 215 (1914)

292 See Felix Frankfurter, “The Due Process Clause Ought to Go," The New RePubliC, vol 40, AT 113 (1924); Felix Frankfurter, "The Supreme Court as Legislature, THE NEW REPUBLIC, vol. 46, at 158 (1926).

293 William Forbath, note 279 , supra, at 985-86. 
out theories that served to undermine standard defenses of constitutionalism. The theories were as varied as the disciplines they came from. For example, progressive historians - most prominently Charles Beard - offered an account of the Constitution's drafting grounded in the narrow economic interests of the framers. ${ }^{294}$ As Beard himself later conceded, ${ }^{295}$ some of his specific claims were hyperbolic, and most modern scholars think that a purely economic interpretation of the founding is far too simplistic. Nonetheless, Beard's more general thesis - that the Constitution was written at least in part to control and limit popular democracy that threatened important economic interests- has been widely accepted. ${ }^{296}$

Philosophical pragmatists like William James, Charles Peirce, and John Dewey, many of whom were closely aligned with the Progressive movement, offered important arguments that attacked constitutionalism's foundations. ${ }^{297}$ Pragmatists held a radical theory of knowledge that rested on social understanding, rather than correspondence with external truths. ${ }^{298}$ What we claimed to know about the world was always contingently held, experimentally derived, and, as William James famously insisted, subject to test for its "cash value." 299 This epistemological view was, to say the least, in deep tension with the view that a written constitution could or should entrench supposed political truths for all time.

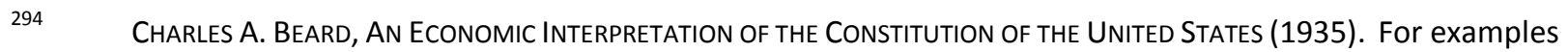
of the apoplectic criticism Beard's work produced, see Peter Novick, That Noble Dream: The “OBJECTIVITY QUESTION" AND the American Historical Profession 96-97 (1988).

$295 \quad$ Beard wrote to Max Farrand that he had been "more belligerent than was necessary and overemphasized a number of matters in order to get a hearing that might not have been accorded to a milder statement." Quoted in id., at 97.

296 See id. (noting that "many other scholars" agreed that "the propertied classes had seen the Constitution as a bulwark against popular democracy"). See generally, WOODY HOLTON, THE UNRULY AMERICANS, note 2, supra. 297 See David M. Rabban, Free Speech in Progressive Social Thought, 74 TEX. L. REV . 95, 98 (1996). On Dewey, James, Peirce and their relationship with the progressive movement, see generally LOUIS MENAND, THE METAPHYSICAL CLUB (2001).

298 See JAMES T. KLOPPENBERG, UNCERTAIN VICTORY: SOCIAL DEMOCRACY AND PROGRESSIVISM IN EUROPEAN AND AMERICAN THOUGHT 1870-1920 at 65 (1986)

299 William JAMES, PRAgMATISM 95-113 (1975). 
The social orientation of Pragmatists also led naturally to a deep skepticism about individual rights. As David Rabban has written, progressives of this stripe "challenged the idea of natural, prepolitical rights held by autonomous individuals in isolation from society, associated law and constitutions with this erroneous conception, and rejected the related position that a laissez-faire government should do little more than protect individual rights." 300

This critique was directed primarily against judicial protection for rights of property and contract, but importantly, leading Pragmatists did not confine their argument to this sphere. For example, before and during World War I, John Dewey, repeatedly equated all individual liberties with "privileges based on inequality." ${ }^{301}$ At the height of the War, he caustically attacked not only antiwar activists but also the civil libertarians who supported them for relying upon "early Victorian platitudes" about "the sanctity of individual rights and the constitutional guarantees." 302

Legal scholars associated with American Legal Realism were closely allied with the Pragmatists and built on Pragmatist insights to advance implicit, and occasionally explicit, attacks on constitutionalism. Realist scholars shared with Pragmatists a deep skepticism about deriving definite results from general values like liberty and equality. Even more specific legal rules and precedents could easily be manipulated to produce a wide variety of results litigated cases. Judges were therefore inevitably pursuing contestable political or policy agendas when they decided cases. Realists insisted that these agendas should be discussed openly and not be obscured by claims that judges were mechanically following the Constitution. ${ }^{303}$

$300 \quad$ David M. Rabban, note 297, supra, at 958.

$301 \quad$ Id., at 966.

302 Id., at 956 . After the war ended, Dewey changed his mind and became an active civil libertarian. Id., at 957.

303 See generally Morton J. HoRWITZ, THE TRANSFORMation of AMERICAN LAW, 1870-1960: THE CRISIS OF LEGAL Orthodoxy (1992); Wilfred E. Rumble, AMerican Legal Realism: SKepticism, Reform, AND the Judicial Process (1968). For a collection of realist texts, see AMERICAN LEGAL REALISM ( William W. Fisher III, Morton J. Horwitz, \& Thomas Reed, eds. 1993). For a revisionist account, see BRIAN Z. TAMANAHA, BEYOND THE Formalist-REALIST Divide: THE ROLE OF POLITICS IN JUDGING (2010). 
This rule skepticism, distrust of abstractions, and obsession with instrumental rationality translated easily into criticism of the main tools of constitutionalism. Most realists were convinced that judges who enforced supposed constitutional guarantees like freedom of contract or protection of private property were not acting out of constitutional compulsion, but out of a set of deeply contestable political views that they were foisting on the rest of the country. As Oliver Wendell Holmes wrote in his celebrated dissent in Lochner v. New York, courts should not decide cases "based upon an economic theory which a large part of the country does not entertain." ${ }^{304}$ In the same opinion, Holmes, who was deeply influenced by the Pragmatists and a pioneer of Legal Realism, ${ }^{305}$ insisted that "[g]eneral propositions do not decide concrete cases," because decisions "depend on a judgment or intuition more subtle than any articulate major premise." ${ }^{306}$ For Holmes, it followed that there should be a sharply constrained role for judges enforcing supposed constitutional commands. In particular, judges should be very reluctant to use the liberty protection of Fourteenth Amendment "to prevent the natural outcome of a dominant opinion." ${ }^{307}$

Progressive economists like John Commons, Thorstein Veblen, Walton Hamilton, and Robert Hale, who pioneered an institutional approach, suggested still another line of attack on constitutionalism. Institutional economists insisted that the "laws" of economics were not autonomous. Instead, market outcomes depended upon surrounding institutions. ${ }^{308}$ Although all the institutionalists criticized the laissez-faire assumptions that lay behind much of Lochner-era constitutionalism, Hale, a

\footnotetext{
$304 \quad$ Lochner v. New York, 198 U.S. 45, 75 (1905) (Holmes, J., dissenting).

305 See LouIS MenAND, The MetaPhysical ClUB, note 296, supra, at xx.

$306 \quad$ Lochner v. New York, 198 U.S. 45, 75 (1905) (Holmes, J., dissenting)

$307 \quad$ Id.

308 See generally KAP K. WILLIAM, THE FOUNDATIONS OF INSTITUTIONAL ECONOMICS (2011); GEOPFFREY MARTIN HODGSON, THE EVolution of INSTITUtional ECONOMICS: AGENCY, StruCtURE, AND DARWINISM IN AMERICAN INSTITUTIONALISM (2004).
} 
Harvard-trained economist who spent most of his career at Columbia Law School, offered a more far reaching critique that held the potential to undermine any sort of constitutional guarantees. ${ }^{309}$

In a path-breaking article, Hale brought into question core constitutional dichotomies like the difference between coercion and freedom or the public and private. ${ }^{310}$ As he pointed out, constitutional law treated government action as presumptively coercive and therefore requiring restraint and private action as presumptively free and therefore requiring protection. In fact, though, virtually all market transactions could be characterized as coercive. A worker who accepted low wages and bad working conditions did so only because the employer was able to threaten him with starvation if he did not comply. Government nonintervention did not make this worker free; instead, it left him vulnerable to this private coercion, which the government could alleviate by restructuring the market. It did not follow, however, that this restructuring would create a world of perfect freedom. If the worker had more market power, then she could coerce the employer.

The upshot was that the link between constitutional rights and freedom was severed. Because coercion was everywhere, it was no longer a useful analytic category. One might still favor public policies based upon their efficacy or upon who was empowered by them, but the goal of achieving universal freedom, and with it the notion of constitutional rights as a protection for individual autonomy, dropped out of the picture.

Although Hale himself did not extend his argument, there was no obvious way to limit his analysis to market "freedoms." Just as "freedom" of contract permitted employers to coerce workers, so too, "freedom" of speech, for example, allowed media owners to coerce people who wanted access to the means of effective communication. Of course, constitutions might still structure political outcomes, and people who favored certain outcomes would therefore favor the structures that

\footnotetext{
309 For a good account of Hale's life and thought, see BARBARA FrIED, THE PROGRESSIVE ASSAULT ON LAISSEZ FAIRE: Robert Hale AND the FirSt LAW AND ECONOMics MOVEMENT (1998).

310 See Robert L. Hale, Coercion and Distribution in a Supposedly Non-Coercive State, 38 POL. SCI. Q. 470 (1923).
} 
produced them. But if one took Hale's ideas seriously, the historic conception of constitutional law as a neutral, apolitical protection for human liberty was no longer plausible.

3. The Special Case of Franklin Roosevelt. I know of no evidence that Franklin Roosevelt was directly influenced by any of the Progressive thinkers discussed above. Unlike his cousin in 1912, the younger Roosevelt made no reference to constitutional reform in his election campaign of 1932. Unlike Lincoln and Jefferson, he never confessed to violating the Constitution. Nonetheless his administration produced a constitutional revolution that shook the foundations of standard constitutionalism.

Although he attended Columbia Law School, the younger Roosevelt was not especially well versed in constitutional law and seems to have thought little about the subject. ${ }^{311}$ Upon assuming office, however, he quickly became aware of the manner in which constitutional constraints might impede his effort to deal with the Depression. Roosevelt had little patience with abstractions or impediments to effective action ${ }^{312}$ and, so, little patience with these constraints. His efforts to overcome them so as to deal with the Depression and then with the War led him to positions that deviated sharply from standard constitutional doctrine and, ultimately, to an understanding of how constitutionalism might be refashioned in a nonlegalistic manner.

The saga begins with Roosevelt's first inaugural address, famous for his declaration that "the only thing we have to fear is fear itself." ${ }^{313}$ Less famous, but more important to this narrative, was Roosevelt's elliptical, but nonetheless unmistakable threat that if Congress did not act, he would assume extraordinary powers:

Our Constitution is so simple and practical that it is possible always to meet extraordinary needs by changes in emphasis and arrangement without loss of essential form...

It is to be hoped that the normal balance of executive and legislative authority may be wholly adequate to meet the unprecedented task before us. But it may be that an unprecedented

\footnotetext{
311 See Frank Freidel, Franklin D. Roosevelt: A Rendezvous With Destiny xx (1990).

312 See James MAcGregor Burns, ROOSEVELt, THE LION AND THE Fox XX (1984)

313 See "Franklin Roosevelt, First Inaugural Address, March 4, 1933" available at http://www.bartleby.com/124/pres49.html
} 
demand and need for undelayed action may call for temporary departure from that normal balance of public procedure.

I am prepared under my constitutional duty to recommend the measures that a stricken nation in the midst of a stricken world may require. These measures, or such other measures as the Congress may build out of its experience and wisdom, I shall seek, within my constitutional authority, to bring to speedy adoption.

But in the event that the Congress shall fail to take one of these two courses, and in the event that the national emergency is still critical, I shall not evade the clear course of duty that will then confront me. I shall ask the Congress for the one remaining instrument to meet the crisisbroad Executive power to wage a war against the emergency, as great as the power that would be given to me if we were in fact invaded by a foreign foe. ${ }^{314}$

This language is more important for the mindset that it revealed than for any immediate action that it presaged. In fact, with the possible exception of his arguably illegal executive order declaring a bank holiday, Roosevelt made no early attempts to upset the basic constitutional structure. A compliant Congress never put him to the test. ${ }^{315}$ The passage nonetheless reveals two crucial aspects of Roosevelt's thought: his willingness to depart from widespread assumptions about constitutional limits when necessary to meet an emergency, and his ability to justify these departures by a rereading of the Constitution as a "simple and practical" document that did not impose rigid restraints.

Although Roosevelt did not establish the kind of dictatorship that some hoped for and others feared, there can be no doubt that the early New Deal upset standard conceptions of federalism and separation of powers. Many New Deal reforms had antecedents in earlier legislation. Still, when taken together, nothing in our constitutional experience rivaled them. Never before had the national government assumed such comprehensive power over the economy, and never before had Congress delegated so much authority and discretion to the executive branch.

Not surprisingly, these measures elicited constitutional challenge. In meeting that challenge, Roosevelt never expressly asserted his right to violate the Constitution. Indeed, he often asserted his reverence for the document. But that reverence was based on an idiosyncratic reading of it that

314

315
Id.

See Jeff Shesol, Supreme Power: Franklin Roosevelt vs. The Supreme Court xx (2010) 
combined a departmentalist assertion of his independent authority to interpret the Constitution with a substantive interpretation that eliminated virtually all occasions for violation.

Roosevelt's departmentalism was reflected in decisions made from the beginning to the end of his presidency. Early on, when it appeared that the Supreme Court might invalidate legislation that altered contracts providing for payment in gold, he made plans, never executed because the Court upheld the legislation, to utilize extraordinary measures that would circumvent the Court's decision. ${ }^{316}$

Later, when the Court did invalidate some important New Deal programs and threatened to invalidate more of them, Roosevelt considered and ultimately decided against the remedy of constitutional amendment. He seems to have rejected this course in part because he insisted on the correctness of his own interpretation of the Constitution under which no amendment was necessary. Instead, he sought to discipline the Court by increasing its size. At first, he disingenuously argued for Court packing on the ground that it was necessary to relieve the workload of superannuated justices, but eventually he acknowledged what was obvious to everyone - that the legislation was designed to privilege his own constitutional interpretation over the views of the judiciary. ${ }^{317}$

Roosevelt's court-packing plan failed, but he ultimately managed to transform the Court through the power of appointment. But even after the Court was populated by justices he himself had appointed, Roosevelt continued to insist on his independent right to interpret the Constitution. When German saboteurs were caught on American territory during World War II, Roosevelt arranged for the men to be tried before a hastily convened military commission. He also made clear that he would adhere to these procedures no matter what a court said. As Attorney General Francis Biddle later recounted, he announced that "“I want one thing clearly understood, Francis. I won't give them up ... I

\footnotetext{
$316 \quad$ Id., at $x x$.

317 For a full account, see id., at xx-xx.
} 
won't hand them over to any United States marshal armed with a writ of habeas corpus.

Understand?"318 Faced with the prospect of being ignored, the Supreme Court caved. It announced a per curiam decision upholding Roosevelt's actions the day after oral argument, and did not get around to releasing its opinion in the case until after the men had been executed. ${ }^{319}$

Roosevelt's substantive view of the Constitution was unorthodox to say the least. Broadly speaking, there were two branches to his thinking: a rejection of technical, constitutional limitations on government power, and an embrace of affirmative rights. His first inaugural briefly invoked the first view when he spoke of the Constitution as a "simple and practical" document. ${ }^{320}$ He argued for this position in more detail in his Constitution Day speech of 1937, one of the greatest yet least remembered major speeches of his Presidency.

The speech came in the immediate wake of the defeat of his Court packing plan and on the one hundred fiftieth anniversary of the Constitution. Speaking to a huge throng from the base of the Washington Monument, ${ }^{321}$ Roosevelt declared that " $t$ the men who wrote the Constitution were the men who fought the Revolution [who] had watched a weak emergency government almost lose the war." 322 They created "a layman's document" he insisted "not a lawyer's contract." ${ }^{323}$ It "cannot be stressed too often," he claimed, that "Madison, most responsible for it, was not a lawyer, nor was Washington or Franklin, whose sense of the give-and-take of life had kept the Convention together." The Constitution, therefore was a "charter of general principles, completely different from the

\footnotetext{
$318 \quad$ FRANCIS BIDDLE, IN BRIEF AUTHORITY XX (1962).

319 See ex parte Quirin, 317 U.S. 1 (1942).

320 See note 313 , supra.

321 For a description of the setting for the speech, see JEFF SHESOL, note 315, supra, at xx.

322 See "Franklin D. Roosevelt, Address on Constitution Day, September 17, 1937, at http://www.presidency.ucsb.edu/ws/?pid=15459.

$323 \quad$ Id.
} 
'whereases' and the 'parties of the first part' and the fine print which lawyers put into leases and insurance policies and installment agreements." ${ }^{324}$

It naturally followed from this conception of the Constitution that the Supreme Court should not have the last word in enforcing it. "Contrary to the belief of many Americans, the Constitution says nothing about any power of the Court to declare legislation unconstitutional." Instead, "[a]gain and again the Convention voted down proposals to give the Justices of the Court a veto over legislation." ${ }^{325}$ Roosevelt saw himself as participating in the latest skirmish in a one hundred fifty year-old battle between "those who would preserve the original broad concept of the Constitution as a layman's instrument of government" and the judges and lawyers "who would shrivel the Constitution into a lawyer's contract." Ultimately, he insisted, the American people would be victorious over "those who professionally or politically talk and think in purely legalistic phrases" and "cry 'unconstitutional' at every effort to better the conditions of our people." ${ }^{326}$

Superficially, these assertions look like claims about how the Constitution should be read, rather arguments for why it should be disobeyed. Once again, however, the line between constitutional interpretation and constitutional defiance is indistinct. A constitution that is not "legalistic," that contains only broad principles to structure discussion, and that is flexible enough to meet current needs (according to whom?) need not be disobeyed. This reading of constitutional text turns Realist rule skepticism into a self-fulfilling prophesy. Roosevelt's simple and flexible constitution was open-ended enough to support whatever he wanted to accomplish, especially when it was yoked to a decentralized system of enforcement that deprived courts of final interpretive authority.

For just this reason, Roosevelt saw no contradiction between constitutional obligation on the one hand and revolutionizing American government on the other. His constitution was capacious

Id.

Id.

326 Id. 
enough to support not only pervasive national regulation of the American economy and the creation of the administrative state, but also the internment of Japanese Americans ${ }^{327}$ and prosecution of dissenters against the War. ${ }^{328}$

The second branch of Roosevelt's theory of the Constitution flipped the historic association between constitutionalism and negative rights. Drawing on a generation of Progressive thought, Roosevelt argued that the Constitution required the subordination of the private sphere to government regulation, rather than the protection of the private sphere from government overreaching.

Focus on Roosevelt's battle with the Supreme Court has tended to obscure this truly radical branch of New Deal jurisprudence. The argument over the constitutional validity of the New Deal turned on the extent of the political branches' discretionary power, and Roosevelt's ultimate victory loosened constitutional constraints. But Roosevelt was not satisfied with merely discretionary power. He argued that the Constitution compelled government intervention - the very thing that, the Constitution was conventionally interpreted to prohibit.

There were hints of this position going back to his original 1932 campaign, ${ }^{329}$ but Roosevelt spelled out his theory most clearly when he proposed a "second bill of rights" in a speech to Congress in early $1944 .{ }^{330}$ In his view, the first Bill of Rights had "proved inadequate to assure us equality in the pursuit of happiness." This was so because "true individual freedom cannot exist without economic

327 See Korematsu v. United States, 323 U.S. 214. For an account, see PETER H. IRONS, JUSTICE AT WAR: THE STORY OF THE JAPANESE-AMERICAN INTERNMENT CASES (1983).

328 For an account of Roosevelt's persistent interest in jailing critics of the war, see GEOFFREY R. STONE, PERILOUS TIMES, note 116 supra, at $\mathrm{xx}-\mathrm{xx}$

329 In his Commonwealth Club address, for example, he argued that "the exercise of . . property rights might so interfere with the rights of the individual that the Government, without whose assistance the property rights could not exist, must intervene, not to destroy individualism, but to protect it." Franklin D. Roosevelt, Campaign Address on Progressive Government at the Commonwealth Club (Sept. 23, 1932), in 1 The Public Papers and Addresses of Franklin D. Roosevelt 657 (Samuel I. Rosenman ed., 1938) at 746.

330 See "State of the Union Message to Congress, January 11, 1944," available at http://www.fdrlibrary.marist.edu/archives/address text.html. For a discussion of the speech and its influence, see Cass R. Sunstein, Constitutionalism after the New Deal, 101 HARV. L. REV. 421, 423 (1987). For an illuminating debate about the speech, see Cass R. Sunstein \& Randy Barnett, Constitutive Commitments and Roosevelt's Second Bill of Rights, 53 DRAKE 205 (2005). 
security and independence." Accordingly, the country needed a new bill of rights which included the right to "a useful and remunerative job," the right to "earn enough to provide adequate food and clothing and recreation," the right to "a decent home" the right to "a good education," and the right to "adequate medical care and the opportunity to achieve and enjoy good health." 331

There is an obvious tension between these two branches of Roosevelt's constitutional jurisprudence. If the Constitution was not a legally enforceable document, how did it create a legal right to the positive goods that Roosevelt listed? The tension is lessened, although not completely resolved, by the fact that this second Bill of Rights was, apparently, to be implemented by legislation rather than judicial decree. ${ }^{332}$ By labeling them a "Bill of Rights," Roosevelt seemed to imply that Congress was under an obligation to enact the measures he proposed. But by remitting the question to the political sphere, he emphasized yet again that for him constitutional "rights" were a starting point for political negotiation, not fixed and inflexible legal commands.

The more serious tension, though, is between the second Bill of Rights and the standard tools of constitutional analysis. That analysis treated private markets as a baseline closely associated with individual liberty. On this view, speech was free so long as Congress made no laws, and the people were secure in their persons, houses, papers, and effects so long as the government conducted no unreasonable searches and seizures.

Roosevelt's second Bill of Rights dissolved this link and, so, left constitutional law without grounding from which rights deprivations could be measured. If true constitutional freedom required not just the protection from government but also the protection of government, then how were we to evaluate government coercion that increased the freedom of some by depriving others of freedom? On

\footnotetext{
331 See "State of the Union Message to Congress, January 11, 1944," note 330, supra.

332 Roosevelt did not call for a formal constitutional amendment or for judicial decisions implementing the Second Bill of Rights. Instead he "ask[ed] the Congress to explore the means for implementing this economic bill of rights- for it is definitely the responsibility of the Congress so to do." Id.
} 
a view like this, the internment of Japanese Americans or suppression of wartime dissent might be not just constitutionally permissible, but actually constitutionally mandatory if they were necessary to vindicate the positive right to government protection.

Moreover, once the link between the private sphere and freedom was severed, "rights" could no longer be treated as absolutes. There were inevitably rights on both sides of the ledger. Enforcement of rights meant balancing some claims against others. Balancing, in turn, requires assigning relative values to the claims to be balanced against each other. Because these values are not specified in the Constitution, the process of value assignment is inevitably political rather than legal.

Roosevelt succeeded in remaking the Supreme Court and opening the discretionary space for economic regulation, but the truly radical implications of his constitutional thought and, more broadly, the general Progressive critique of constitutionalism, never gained a firm foothold. By the time he spoke in 1944, Progressive skepticism was already beginning to fall into disrepute. The rise of fascism in Europe gave a different cultural meaning to claims that law reflected no more than power, ${ }^{333}$ and the repopulation of the Supreme Court with Roosevelt-appointed judges made Progressives themselves more at ease with judicial enforcement of constitutional norms. Moreover, the formation of a New Deal coalition that included racial, religious, and political minorities turned support for civil rights and civil liberties protections into a political necessity.

The upshot was the Carolene Products settlement under which the recently empowered Roosevelt justices distinguished sharply between property rights, indefensibly privileged by the so-called Lochner court, and civil and political rights, justifiably privileged by the new, and newly-enlightened Roosevelt Court. ${ }^{334}$ The settlement ultimately proved unstable because, as an earlier generation of 
Progressives understood, both civil and political rights on the one hand and property and contract rights on the other depended on the specification of a baseline formed by market transactions. ${ }^{335}$ Eventually, the settlement unraveled. Before it did, however, it laid the groundwork for the emergence of the Warren Court and the brief flourishing of a moderate-left version of constitutionalism.

\section{E. The Warren Court}

Mid-twentieth century constitutionalism provides support for both constitutionalists and constitutional skeptics. Some commentators remain nostalgic for the Court that gave us Brown, ${ }^{336}$ Miranda, ${ }^{337}$ and Reynolds ${ }^{338}$ and believe that its achievements demonstrate the unrealized possibilities of liberal constitutionalism. ${ }^{339}$ But the more dominant modern view is that the Warren Court's obvious failures serve as a cautionary tale about the limits of judicially centered constitutional power. ${ }^{340}$ On this view, the Court's history is part of a narrative that emphasizes what Mark Tushnet has aptly called the chastening of constitutional aspiration. ${ }^{341}$

1. The Civil Rights Revolution. The struggle over the Second Reconstruction offered a replay of the fusion of constitutional and anticonstitutional rhetoric that marked the antebellum period. Both sides used standard constitutional tools to advance their positions, but, when necessary, both sides also resorted to tactics and arguments that challenged constitutional norms.

The efforts of southern opponents of racial equality were less interesting because less original. Instead of developing new constitutional theories, they recycled old ones. Nullification, interposition,

335 For discussions, see LouIs Michael SEIDMAN \& MARK V. Tushnet, REMNANTS Of BeLIEF: CONTEMPORARY Constitutional Issues 26-90 (1996); Louis Michael SeIDMAN, The Dale Problem: Property and Speech under the Regulatory State, 75 U. CHI. L. REV. 1541 (2008).

$336 \quad$ Brown v. Board of Education, 347 U.S. 483 (1954).

$337 \quad$ Miranda v. Arizona, 384 U.S. 436 (1966).

$338 \quad$ Reynolds v. Sims, 377 U.S. 533 (1964).

339 See, e.g., Morton J. Horwitz, The Warren Court and the Pursuit of Justice, 50 WASH \& LEE L. REV. 5 (1993).

340 See, e.g., Lucas A. PoWe, The Warren Court And American Politics (2000); Fred P. Graham, The Self-INFLicted Wound (1970).

341 See Mark Tushnet, Foreword: The New Constitutional Order and the Chastening of Constitutional Aspiration, 113 HARV. L. REV. 29 (1999). 
and states' rights made new appearances, and John Calhoun's theoretical musings gained new popularity. Once again, these arguments were supplemented with extraconstitutional rhetoric and actions. While lawyers made sophisticated legal arguments in court, thugs coupled revolutionary rhetoric with violence in the streets. ${ }^{342}$

In contrast, opponents of racial segregation pioneered new legal and extralegal tactics, ${ }^{343}$ but the division between and paradoxical conjunction of constitutional and skeptical arguments was not new at all. The division is neatly if over simply personified by the rivalry between Thurgood Marshall and Martin Luther King. Marshall led a legal campaign insisting on respect for the rule of law. Like Marshall, King grounded his arguments in constitutional rhetoric, but he deemphasized detailed legal argument before courts. Instead, he pursued a strategy of civil disobedience and direct action. ${ }^{344}$ Even a half century later, historians argue about which strategy was more successful. The ambiguity is symbolized by the Montgomery bus boycott. King's leadership of the boycott galvanized advocates of civil rights across the country, but the boycott came to a successful conclusion only after Marshall secured a holding from the Supreme Court that segregated public transportation was unconstitutional. ${ }^{345}$

Doubtless both Marshall and King contributed to the change in public attitudes that ultimately produced change on the ground. Importantly, however, when the change finally came, it was not the

342 For accounts, see GEORGE LEWIS, MASSIVE RESISTANCE: THE WHITE RESPONSE TO THE CIVIL RIGHTS MOVEMENT $27-122$ (2006); Michael J. Klarman, From Jim Crow to Civil Rights: The Supreme Court and the Struggle for RaCial Equality 330-34, 350-55 (2004).

343 See, e.g., MARK Tushnet, The NAACP's Legal Strategy Against Segregated EducAtion, 1925-1950 (1988);

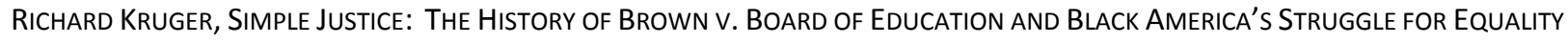
(2004).

344 See Mark Tushnet, Making CIVIL RIghts LAW: Thurgood MARShall ANd the Supreme Court, 1936-1961at 305

(1994) ) ('[Marshall] was . . reported to have called King a 'first-rate rabal-rouser,' and complained about always 'saving King's bacon.'")

345 See id., at 302-04 (1994); DAVID J. GARRY, BEARING THE CROSS: MARTIn LUTHER King, JR. AND THE SOUTHERN CHRISTIAN LEADERSHIP CONFERENCE 11-82 (1986) 
direct product of the judicial constitutionalism of the 1950s. Instead, it came about because of political changes that culminated in the Johnson administration's forceful support for civil rights in the 1960 s. $^{346}$ The question of causation is made still more complicated by the fact that neither King nor Marshall drew a sharp distinction between legal and political struggle. King pursued the struggle in the streets, but, like many before him, he linked constitutional and natural rights rhetoric. ${ }^{347}$ Moreover, as the Montgomery example illustrates, he sometimes depended on legal intervention to sustain the movement. Marshall pursued victories in court, but clearly understood that the litigation campaign was a tool for political mobilization. ${ }^{348}$

Importantly, the Warren Court itself also straddles the divide between our constitutional and skeptical traditions. On the one hand, Brown constitutes a remarkable reformulation of constitutional law to advance the cause of racial liberation. On the other, there is evidence that at least some of the justices voted for the result out of moral and political conviction, rather than because they thought it was legally justified. ${ }^{349}$ That fact is hardly surprising given the shaky support for the result in standard

346 See Michael J. KLARMAN, note 342, supra, at 363 ("The 1964 Civil Rights Act, not Brown was plainly the proximate cause of most school desegregation in the South).

$347 \quad$ For example, in his famous "Letter from a Birmingham Jail," King asserted that "We have waited for more than 340 years for our constitutional and God given rights" and that "[a]n ordinance becomes unjust when it is used to maintain segregation and deny citizens the First -Amendment privilege of peaceful assembly." "Letter from a Birmingham Jail," available at http://www.africa.upenn.edu/Articles_Gen/Letter_Birmingham.html. 348 See MARK TUSHNET, MAKING CIVIL RIGHTS LAW, note 344, supra, at 42 ("The NAACP's legal work was directed at eliminating segregation, and its lawyers understood that ending segregation required a mobilized AfricanAmerican community.")

349 See, e.g., MARK TUSHNET, MAKIng CIVIL RIGHTS LAW, note 344, supra, at 189, 191 (for Justice Robert Jackson, segregation cases posed question of politics rather than law); id., at 211 (quoting Jackson as saying that "this is a political question," that the problem for segregation's opponents was "to make a judicial basis for a congenial political conclusion," and that "as a political decision, I can go along with it." MiCHAEL J. KLARMAN, note 342 supra, at 296 (quoting Jackson as saying that "[there is] [n]othing in the text that says this is unconstitutional. [There is] nothing in the opinions of the courts that says it's unconstitutional. Nothing in the history of the $14^{\text {th }}$ amendment [says it's unconstitutional]. On [the] basis of precedent [I] would have to say segregation is ok"); id., at 295 (concluding that "[w]hat [Justice Felix] Frankfurter found compelling was the moral, not the legal, argument against segregation in the nation's capital"; id., at 298 (concluding that "if [Justice Hugo Black] is to be taken at his word about his method of constitutional interpretation [his] personal views about segregation, not his legal interpretation, must explain his vote"). 
constitutional materials. Brown was almost certainly inconsistent with the original expected application of the fourteenth amendment and with decades of precedent. ${ }^{350}$ Instead of utilizing the usual tools of constitutional analysis, ${ }^{351}$ Chief Justice Warren relied upon social science evidence of dubious relevance and reliability. ${ }^{352}$

Moreover, even if Brown, itself, can be constitutionally justified, the Court's other decisions around the same period fit more easily within the skeptical tradition. On the same day that Brown was decided, the Court held that segregation in the District of Columbia violated the fifth amendment's due process clause despite the fact that the clause was written at a time when it was reasonably clear that the Constitution protected slavery. ${ }^{353}$ The justice's conference notes make clear that Brown II's "all

350 At the time the fourteenth amendment was adopted, five northern states excluded African Americans from public schools and eight additional northern states had segregated schools. There is no indication that those ratifying the fourteenth amendment thought that these practices would have to change because of the Amendment. RICHARD KLUGER, SIMPLE JUSTICE 633-34 (1976). The same Congress that enacted the Fourteenth Amendment passed legislation permitting segregation in District of Columbia schools. Drafters of the 1866 Civil Rights Act, which the fourteenth amendment was designed to constitutionalize, specifically stated that the Act did not interfere with segregated education. See Statement of James Wilson, Cong. Globe, 39th Cong., $1^{\text {st }}$ Sess. 111718 (1866). But see Michael McConnell, Originalism and the Desegregation Decisions, 81 Va. L. Rev. 947 (1955) (arguing that the framers intended to outlaw school segregation).

351 The Court concluded that the fourteenth amendment's history was "inconclusive" and stated that "we cannot turn the clock back to 1868 when the Amendment was adopted." Brown v. Board of Education, 347 U.S. 483, 491-92 (1954).

352 See id, 494 n. 11 (1954) (citing social science studies for the proposition that segregation had a detrimental psychological effect on African American children). On the dubious nature of the evidence, see Mark Yudof, School Desegregation: Legal Realism, Reasoned Elaboration and Social Science in the Supreme Court, 42 LAW CONTEMP. PROBLS. 57, 70 (1978 (concluding that "[v]irtually everyone who has examined the question now agrees that the Court erred [in relying on the social science data.]")

${ }_{353}$ Bolling v. Sharpe, 347 U.S. 497 (1954). For doubts about the legal, as opposed to political, underpinnings of Bolling, see Michael KLARMAN, note 242, supra, at 341. See also Michael McConnell, Michael McConnell (concurring in the judgment), in WHAT BROWN V. BOARD OF EDUCATION SHOULD HAVE SAID 158, 166 (Jack M. Balkin ed., 2001) (Bolling "without foundation"); JOHN HART ELY, DEMOCRACY AND DISTRUST 21 (1980) (Bolling "gibberish both syntactically and historically"); Sanford Levinson, Constitutional Rhetoric and the Ninth Amendment, 64 CHI-KENT L. REV. 131, 147 (1988) ("no satisfactory theory" justifies Bolling). But see David E. Bernstein, Bolling, Equal Protection, Due Process, and Lochnerphobia, 93 GEo. L. J. 1253 (2005) (defending Bolling); Peter J. Rubin, Taking Its Proper Place in the Constitutional Canon: Bolling v. Sharpe, Korematsu, and the Equal Protection Component of the Fifth Amendment Due Process Clause, 92 U. VA. L. REV. 1879 (2006) (same). 
deliberate speed" equivocation was the result of a political compromise dictated by the felt need to avoid violent resistance, rather than by constitutional law. ${ }^{354}$ Brown had announced that school segregation was unconstitutional because of the special role of education and because of its effects on the hearts and minds of school children, ${ }^{355}$ but, to the dismay of constitutionalists, ${ }^{356}$ the Court, without explanation, announced that the same rule applied in contexts that had nothing to do with children or education. ${ }^{357}$ When the Court was faced with a challenge to anti-miscegenation laws in the immediate wake of Brown, it disposed of the case in a manner that most commentators consider lawless. ${ }^{358}$ Internal materials regarding the justices' deliberations make clear that that its actions were motivated by the desire not to intensify southern resistance rather than by constitutional fidelity. ${ }^{359}$

All of these decisions suggest that the justices saw their role as political rather than legal. Of course, when the Constitution served their purposes, they used constitutional rhetoric. It does not follow, though, that the justices were ultimately motivated by constitutional obedience. When

\footnotetext{
${ }^{354}$ See MARK V. TUSHNET, note 344 supra, at 220 (noting that concern that "'passions' associated with desegregation might lead to violent resistance ... substantially affected the Court's deliberations.")

355 See Brown v. Board of Education, 347 U.S. 483, 493 (1954) (supporting Court's holding on the ground that "it is doubtful that any child may reasonably be expected to succeed in life if he is denied the opportunity of an education.")

356 See, e.g., John Hart Ely, If at First You Don't Succeed, Ignore the Question Next Time? Group Harm in Brown v. Board of Education asnd Loving v. Virginia, 15 CONST. COMMENT. 215, 218 (1998) ("it seems rather transparently the case that Chief Justice Warren's remarks about how segregated schools can impede the learning opportunities of black children, eloquent as they were, had little if any bearing on the per curiam orders that came down almost immediately thereafter, desegregating buses, golf courses and beaches, without any psychological buttresses of the sort that were at least attempted in Brown "); Alexander M. Bickel \& Harry H. Wellington, Legislative Purpose and the Judicial Process: The Lincoln Mills Case, 71 HARVARD L. REV. 1, 3 (1957) ("This is not to say that the per curiam orders were wrong. Nor is it to say that they could not be founded in reason, only that the Court made no effort to do so.")

$357 \quad$ See Gayle v. Browder, 352 U.S. 903 (1956) (buses); Homes v. City of Atlanta, 350 U.S. 879 (1955) (municipal golf course); Mayor of Baltimore vb. Dawson, 350 U.S. 877 (1955) (public beaches and bathhouses). $358 \quad$ See Naim v. Naim, 350 U.S. 985 (1956) (finding without explanation that the case was devoid of a properly presented federal question). For the leading example of criticism by commentators, see Gerald Gunther, The Subtle Vices of the' Passive Virtue:' A Comment on Principle and Expediency in Judicial Review, 64 CoUMB. L. REV. I, 11-12 (1964).

${ }_{359}$ For example, Justice Frankfurter stated that the legal challenge could "not be dismissed as frivolous" but that "moral considerations" for dismissing the appeal "far outweigh[ed] the technical considerations in noting jurisdiction" because deciding the case would risk "thwarting or seriously handicapping the enforcement of [Brown]. Quoted in MICHAEL J. KLARMAN, note 342, supra, at 322. For an account of the justices' desperate efforts to get rid of the case, see id., at 322-23.
} 
constitutional obligation got in the way, they exhibited a remarkable readiness to override legal constraints.

2. The Warren Court's legacy. In addition to its support for civil rights, the Warren Court revolutionized criminal procedure, ${ }^{360}$ significantly expanded free speech protections, ${ }^{361}$ provided important guarantees for voting rights, ${ }^{362}$ and took tentative first steps toward providing constitutional protection for the poor. ${ }^{363}$ If one includes the early years of the Burger Court in the historical reckoning, then the protection of reproductive rights ${ }^{364}$ and guarantees of gender equality ${ }^{365}$ should be added to the list of accomplishments.

Commentators argued then, and continue to argue now, about the extent to which these decisions were manifestations of constitutional fidelity. Even on the assumption that they were, though, the more important question for present purposes is what the relationship is between the Warren Court experience and the skeptical tradition. On the one hand, it might be argued that the Warren Court experience demonstrates that judicially enforced constitutional obligation can serve the interests of justice and progress. There can be no doubt that the Court used the Constitution to eradicate the worst forms of racial subjugation. Other Warren era decisions have also shown surprising resilience. Miranda warnings are now part of our culture, ${ }^{366}$ the one-person-one-vote rule remains a

$360 \quad$ See, e.g., Gideon v. Wainwright, 372 U.S. 335 (1963); Mapp v. Ohio, 367 U.S. 643 (1961); Miranda v. Arizona, 384 U.S. 436 (1966).

$361 \quad$ See, e.g., New York Times v. Sullivan, 376 U.S. 2534 (1964); Brandenburg v. Ohio, 395 U.S. 444 (1969).

362 See,e.g., Reynolds v. Sims, 377 U.S. 533 (1964); Harper v. Virginia State Board of Elections, 383 U.S. 663 (1966).

363 See, e.g., Griffin v. Illinois, 351 U.S. 12 (1956); Shapiro v. Thompson, 394 U.ES. 618 (1969); Goldberg v. Kelly, 397 U.S. 254 (1970).

364 See, e.g., Roe v. Wade, 410 U.S. 113 (1973); Carey v. Population Services Intl., 431 U.S. 678 (1977).

365 See, e.g., Reed v. Reed, 404 U.S. 71 (1971); Craig v. Boren, 429 U.S. 190 (1976).

366 See Dickerson v. United States, 530 U.S. 428, 430 (2000) (reaffirming Miranda and acknowledging that Miranda warnings "have become part of our national culture"). 
touchstone in legislative districting, ${ }^{367}$ and despite significant erosions in law ${ }^{368}$ and practice, ${ }^{369}$ the abortion right remains mostly intact. ${ }^{370}$

But there is another side to the story. Writing in the immediate wake of the Warren years, Alexander Bickel argued that the Court would ultimately be judged by its ability to predict the future. He thought that the Court had failed to do so, ${ }^{371}$ and, now that the future has arrived, it seems that he was largely correct. The point is not so much that Warren Court precedent has been overruled, although some of it certainly has been, ${ }^{372}$ as that it has become irrelevant. For example, the effort to end segregated schools was mostly undone by neighborhood school policies superimposed upon residential segregation. ${ }^{373}$ Warren Court criminal procedure reforms failed to prevent historically unprecedented increases in incarceration rates ${ }^{374}$ and a growing racial disproportion in those rates. ${ }^{375}$

367 See, e.g., Bartlett v. Strickland, 128 S. Ct. 1231, 1239 (2009) (Acknowledging that "[i\}t is common ground that state election-law requirements . . . may be superseded by . . . the one-person, one-vote principle of the Equal Protection Clause of the United States Constitution.")

368 See, e.g., Gonzales v. Carhart, 550 U.S. 124 (2007) (upholding ban on "partial birth" abortion).

369 See "Abortion Restrictions Enacted By States," N.Y. Times, available at http://www.nytimes.com/interactive/2014/01/03/us/abortion-restrictions-passed-by-states.html? r=0 (noting that states enacted 70 new abortion restrictions in 2013).

370 See Planned Parenthood v. Southeastern Pennsylvania v. Casey, 505 U.S. 833 (1992) (affirming the "core" of Roe).

371 See Alexander M. Bickel, The Supreme Court And the Idea of Progress (1970).

372 See, e.g., Illinois v. Gates, 462 U.S. 213 (1983) overruling Spinelli v. United States, 393 U.S. 410; Coleman v. Thompson, 501 U.S. 722 (1991) overruling Fay v. Noia 372 U.S. 391 (1963).

373 See e.g., Christopher KNAUSS, Still Segregated, Still Unequal: ANALYZING the IMPACt Of No CHILD LEFt BEHIND ON AfRICAN AMERICAN STUDENTS (2007) (by 2003, 73\% of African American students attending predominantly minority schools, and $38 \%$ of such student attending schools that were over $90 \%$ minority).

$374 \quad$ From 1970 to 2009, the number of people incarcerated in the United States grew from 196,429 to 2.25 million, an increase of more than $1000 \%$. Compare MARGARET WERNER CAHALAN, U.S. DEP'T OF JUSTICE, BUREAU OF

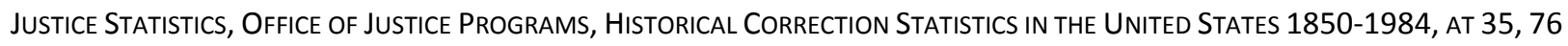
(1986), available at https://www.ncjrs.gov/pdffiles1/pr/102529.pdf (196,429 incarcerated persons in U.S. in 1970) with Heather C. West, Bureau of Justice Statistics, U.S. Dep't of Justice, OfFice of Justice Programs, Prison InMates At MIDYEAR 2009 -STATISTICAL TABLES, TBL. 2 (2010), available at http://bjs.ojp.usdoj.gov/content/pub/pdf/pim09st.pdf $(2,297,400$ incarcerated persons in U.S. in 2009).

$375 \quad$ Black men are more than six times more likely to be imprisoned than white men. See id., at 2. Twenty percent of African American men born between 1965 and 1969 have been imprisoned by the time they reach their early thirties. See Becky Pettit \& Bruce Western, Mass Imprisonment and the Life Course: Race and Class Inequality in U.S. Incarceration, 69 AM. SOC. REV. 151, 151 (2004). See generally MICHELLE ALEXANDER, THE NEW JIM Crowe: Mass incarceration in the Age of Color Blindness (2010). 
Some commentators think that Warren Court decisions have actually worsened these trends. ${ }^{376}$

Similarly, the widespread implementation of political gerrymandering has made a mockery of the notion that one-person-one-vote could produce political fairness. ${ }^{377}$ The Court's hints that economic injustice might be subject to constitutional attack were stillborn. ${ }^{378}$

On a more general level, the Warren Court had at best limited success in convincing the country that judicial power legitimated by constitutional text dictated broad based social reforms. ${ }^{379}$ Today, many Warren Court decisions seem not so much legally wrong as politically naïve. In this sense, attitudes toward the Warren Court mirror contemporary views about the 1960 s as a whole. Many contemporary Americans think of the era as marked by well-meaning and even exhilarating efforts to achieve change, a few of which produced lasting contributions, but many of which backfired or fizzled.

Some of the Warren Court's difficulties were doctrinal. As heirs of the Progressive tradition, the justices often used Progressive analytic techniques to advance their constitutional arguments. Since these techniques were originally developed to criticize constitutionalism, it is not surprising that the fit between them and the Court's constitutional agenda was awkward.

For example, many Progressives criticized standard constitutional analysis that celebrated government neutrality and constraint. They pointed out that standard conceptions of freedom and coercion were dependent on a baseline formed by government actions that shaped the market.

376 See, e.g., William J. Stuntz, The Collapse of American CRIMInAl Justice 220-243 (2011).

377 See, e.g., Sam Wang, "The Great Gerrymander of 2012," N.Y. TIMES, Feb. 2, 2013) (in 2012 House elections, Democrats received 1.4 million more votes than Republicans, but because of gerrymander, Republicans controlled the House by a margin of 234-201).

378 See, e.g., San Antonio v. Independent School Dist. V. Rodriguez, 411 U.S. 1 (1973); Dandridge v. Williams, 397 U.S. 471 (1970).

379 The statement in text assumes that the Court's exercise of judicial power was legitimated by constitutional text. Of course, the Court's many opponents denied that this was true. Either way, the Warren Court experience can be conceptualized as part of the skeptical tradition. 
Government neutrality overlaid on market outcomes, themselves produced by background legal norms, empowered some private actors to coerce other private actors. ${ }^{380}$

Progressives made these arguments in service of criticizing constitutional decisions, but the Warren Court tried to build on them to justify these decisions. Most prominently, Brown refused to accept the facial neutrality of the separate but equal doctrine. Even though both blacks and whites were equally barred from attending each other's schools, when the doctrine intersected with a pervasively racialized social system, it had the effect of producing a racial hierarchy. ${ }^{381}$ The Warren Court thought that the government had an affirmative obligation to eliminate that effect - an obligation that could not be met by facial neutrality alone. This positive rights orientation became increasingly apparent as the Court, faced with massive resistance, mandated remedies that required affirmative, race-conscious efforts to desegregate schools. ${ }^{382}$

Some of the Court's other well-known decisions demonstrate a similar refusal to take market baselines enforced by common law property allocations as a given. For example, cases like Gideon v. Wainwright ${ }^{383}$ and Douglas v. California ${ }^{384}$, guaranteeing a right to counsel in some criminal cases, imposed an affirmative obligation on the state to provide lawyers to people who lacked the funds to pay for them. These decisions rejected a facially neutral policy that denied free lawyers to rich and poor alike in favor of an affirmative duty to relieve at least this disadvantage produced by market allocations. Similarly, the Court's public forum cases ${ }^{385}$ required governments to provide what amounted to a

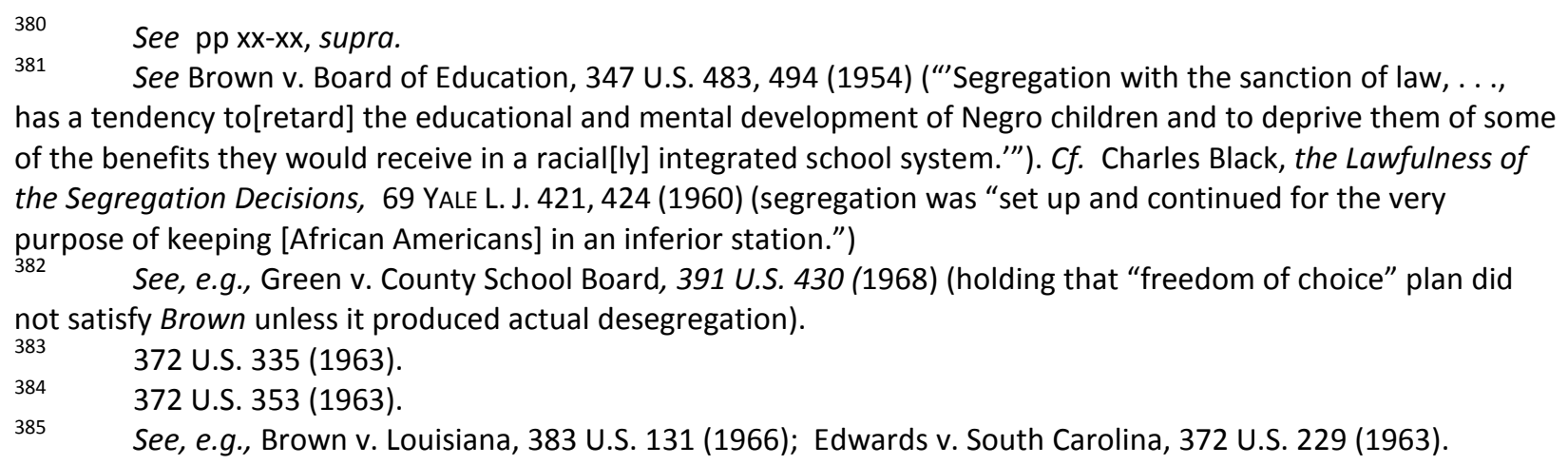


subsidy to speech activities by mandating the free use of public property. New York Times v. Sullivan, ${ }^{386}$ which sharply limited common law libel rules, can also be conceptualized as mandating a free speech subsidy by permitting the press to inflict uncompensated harm on public figures in the interest of increasing the amount of speech.

The problem for the Court was that, just as some Progressives thought, the abandonment of common law baselines left constitutional rights untethered from anything that could give them determinate content. Instead of clear and absolute limits on government power, rights became questions of degree and subject to balancing.

For example, if the state had an affirmative obligation to desegregate schools, then questions naturally arose about how much desegregation was required and at what cost? If lawyers had to be provided to indigent criminal defendants, how skilled did the lawyer have to be? If the first amendment required a subsidy for speech, how much speech was constitutionally sufficient? These are questions that cannot be answered by simple fidelity to a constitutional text. They ultimately rest on politically contestable judgments about the comparative worth of different goods. But if that is all the Court's decisions amounted to, why should they not be within the domain of ordinary politics?

It would be foolish, though, to suppose that the Warren Court's main problem was doctrinal. Instead, its ultimate failure rested on a political miscalculation. The Justices thought that they could harness constitutional obligation to produce meaningful social change. They seemed to think that people would be motivated to do things that they would not otherwise do just because an elite institution told them that the Constitution required this action. It turned out, though that the rhetoric of obligation was insufficiently powerful to convince large numbers of people to accept change that they did not want. Instead, as the political winds shifted and the composition of the Court changed, Warren 
Court interpretations were met with opposing interpretations that mandated different results that were more popular. ${ }^{387}$ The upshot is an experience that strongly reinforces skeptical doubts whether constitutional law can effectively combat the social, political, economic, and cultural forces that are the ultimate determinates of public policy.

\section{F. The Modern Period}

Today, no revered ex-President defends his own constitutional violations, raises questions about intergenerational obligation, or argues that Supreme Court decisions should be reversed by popular referendum. No one of consequence is burning the Constitution or calling it a pact with the devil. A handful of people well outside the mainstream still advocate secession, but no one takes them seriously. Instead, we are treated to the spectacle of members of Congress reading the Constitution aloud before the beginning of a session and of a new requirement that every piece of legislation be accompanied by a defense of its constitutional validity. ${ }^{388}$ Liberals and conservatives alike are fully engaged in constitutional argument. Even some legal academics associated with the left have embraced constitutional originalism. ${ }^{389}$ At least superficially, it seems that the skeptical tradition has run into a dead end.

In this Section, I argue that this conclusion is indeed superficial. Skeptical arguments no longer receive the kind of overt and boisterous support they once did, but one does not have to look very far beneath the surface to see that constitutional skepticism is nonetheless alive and well.

1. Popular skepticism. The public's attitude toward constitutionalism is deeply conflicted. Many Americans profess unquestioning allegiance to the Constitution, ${ }^{390}$ and commentators regularly

\footnotetext{
387 See generally, Lucas A. PoWe, The Warren Court And American Politics (2000); Fred P. Graham, The Self-INflicted WOUND (1970).

388 See Jennifer Steinhauer, “Constitution Has Its Day (More or Less) in the House, N.Y. TIMES, Jan. 7, 2011, at A15.

389 See JACK M. BALKIN, LIVING ORIGINALISM (2011).

390 See note 1, supra.
} 
make constitutional arguments on all sides of public policy issues. But this seeming devotion to the Constitution is married to a deep cynicism about the role that constitutional argument actually plays.

The cynicism finds clear expression in the media's regular identification of judges and justices with reference to the party of the president who appointed them. It is on full display at judicial confirmation hearings, which have turned into undisguised political warfare. ${ }^{391}$ According to polling data, most Americans believe that political considerations play at least some role in Supreme Court decision making. ${ }^{392}$ It escapes almost no one's attention that politicians regularly use constitutional arguments about, for example, health care, crime prevention, and voting rights to support conclusions that they would come to anyway.

This combination of outward devotion to the rhetoric and rituals of constitutionalism with inner doubt and despair is bound to be unstable. The situation is made only worse by the Supreme Court's own ambivalence. Consider, for example, two recent decisions exhibiting the two, rival forms of constitutional analysis currently in vogue. In District of Columbia v. Heller, ${ }^{393}$ both sides conspicuously deployed originalist methodology. Justice Scalia, writing for the Court, found that the original public meaning of the second amendment made the District's gun control statute unconstitutional. Justice Stevens, using the same techniques, found that the original public meaning of the amendment was consistent with the statute. ${ }^{394}$ Both justices filled scores of pages of the United States Reports with

391 See, e.g., StePHen L. CARTER, THE CONfIRMATION MESS (1994). Cf. Geoffrey R. Stone, Understanding Supreme Court Confirmations, 2010 SUP. CT. REV. 381.

392 According to a poll conducted by CBS News in 2012, three quarters of all Americans believe that Supreme Court Justices do not decide cases solely based on legal analysis, but rather "sometimes let their personal or political views influence their decisions." See "Polling Report. Com: Supreme Court/Judiciary" available at http://www.pollingreport.com/court.htm. In another poll, conducted by the Public Religion Research Institute in $2013,55 \%$ of those surveyed thought that Supreme Court Justices were influenced by their own political views in making decisions "a lot," and another $32 \%$ thought that they were influenced "a little." Only $8 \%$ thought that the justices were influenced "not at all."

554 U.S. 570 (2008).

394 Compare, e.g., id., at 584 (relying on $18^{\text {th }}$ century meaning of "bear arms" to conclude that the amendment was violated) with id., at 646 (relying on $18^{\text {th }}$ century meaning of "bear arms" to conclude that the amendment was not violated.) 
detailed analysis of the linguistic structure, dictionary meanings, and popular contemporary understanding of the amendment. Remarkably the upshot was a near standoff. Five justices thought that the statute was clearly inconsistent with the amendment, while four justices thought that it was clearly not.

Of course, all methods of analysis produce disagreement, but two additional facts about the Court's performance make the outcome in Heller especially troubling. First, the difference of opinion over supposedly apolitical matters like semantics and dictionary meaning precisely tracked the ideological differences on the Court. Somehow, all five of the conservative justices read the amendment one way, while all four of the liberal justices read the same language the other way.

Second, virtually all of what the Justices on both sides of the question wrote was deeply irrelevant to the important public policy question that ought to concern us. Gun control poses hard questions about which reasonable people can disagree. Does any sensible person suppose that these questions should be answered by determining what some people thought over two centuries ago in a society that was radically different in culture, technology, and geography?

Many people who think that this is not a sensible way to decide questions like this adhere to the "living constitution" theory of interpretation. On this view, judges should not be limited by the original understanding of constitutional language, but instead should strive to give it modern meaning. ${ }^{395}$ Although Justice Kennedy did not identify it as such, he used this approach in United States v. Windsor, ${ }^{396}$ where he wrote for the Court to invalidate the Defense of Marriage Act. ${ }^{397}$ Justice Kennedy's opinion made no effort to uncover the original meaning of constitutional text or the specific intent of its framers. Indeed, he barely identified the text he relied upon. Instead, his opinion

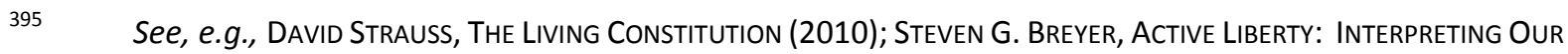
DEMOCRATIC CONSTITUTION (2008).

$396 \quad 133$ S. Ct. 2675 (2013)

$397 \quad 28$ U.S.C. $\S 1738(C)$.
} 
consisted of an extended sermon on the virtues of tolerance and respect for individuals.

In their angry dissenting opinions, Justices Scalia and Alito were entirely correct in pointing out that Kennedy's opinion rested on an implicit, nonconstitutional moral premise - that gay sex and marriage were, at worst, morally neutral and at best an important means of human expression. ${ }^{398}$ One might suppose from this attack that the conservatives stood for principled neutrality in what Justice Scalia has referred to as our "culture war." 399 Unfortunately for them, however, their own votes and opinions in racial affirmative action cases rest on a similarly contestable moral premise. Like Kennedy's opinion in Heller, the opinions written by conservatives in cases about so-called racial preferences never investigate original public meaning. Instead, they rest exclusively on moral and sociological judgments about the supposed evil of racial categorization. ${ }^{400}$

Hypocrisy of this sort is too obvious to miss. Nor does it require deep analysis to discover that the votes in Windsor and in affirmative action cases once again precisely track the Court's political divisions. Given these facts, it is not surprising that that many members of the general public have difficulty taking the Court's constitutional pretensions seriously. ${ }^{401}$ Perhaps more important, though, a surprisingly large number of Americans think that it is a good thing when the Court does not decide cases based solely upon the Constitution. For example, a CBS News Poll conducted in 2013 asked respondents whether, when the Supreme Court decides an important constitution case, it should consider only the legal issue or also "what a majority of the public thinks about the issue." Forty-six

398 See 133 S. Ct., at 2711 (Scalia, J., dissenting); id., at 2718-20 (Alito, J., dissenting).

$399 \quad$ Lawrence v. Texas, 539 U.S. 558, 602 (2003) (Scalia, J., dissenting).

$400 \quad$ I have found no case where justices opposing affirmative action have discussed the original public meaning of the fourteenth amendment. For examples of these justices relying instead on their moral and political views, see, e.g., League of Latin Am. Citizens v. Perry, 548 U.S. 399, 511 (2006) (Roberts, C. J., concurring in part and dissenting in part) ("It is a sordid business, this divving us up by race.");Gratz v. Bollinger, 539 U.S. 244,349 (2003) (Thomas, J.) (voting to invalidate university racial admissions preference in part because "I believe blacks can achieve in every avenue of American life without the meddling of university administrators.")

$401 \quad$ See note 392, supra. 
percent of respondents thought that the justices should confine themselves to the legal issue, but $45 \%$ thought that they should also consider public opinion . ${ }^{402}$ According to another poll, although $69 \%$ of respondents agreed with the statement that "The United States Constitution is an enduring document that remains relevant today," $28 \%$ rejected the statement and agreed, instead, with the view that "[t]he United States Constitution is an outdated document that needs to be modernized." 403

2. Academic skepticism. Virtually all modern scholars of constitutional law begin with some kind of commitment to constitutional fidelity. Only a tiny handful of legal academics overtly raise questions about constitutional obligation. ${ }^{404}$ But despite this fact, constitutional skepticism plays a central role in contemporary constitutional scholarship.

Sometimes, it shows up in quite surprising places. Consider, for example, the "Constitution in exile" movement. Some conservative judges and scholars have argued that much of modern government, including the entire apparatus of the administrative state, violates the Constitution. ${ }^{405}$ Of course, their fervent complaints about this state of affairs are grounded in constitutional fidelity. If one looks beneath the surface however, their argument also supports the skeptical position. After all, if it is really true that for years, broad swaths of legal doctrine have been infected by blatant constitutional violation, then it cannot also be true that constitutional obedience plays a central role in maintaining the stability of our government and culture. In a backhanded way, the claims of the "Constitution in exile" proponents support the skeptical argument that constitutional obedience is unnecessary to hold the country together.

Moreover, if the "Constitution in exile" proponents are correct, we are faced with the daunting

$402 \quad$ See id.

403 See, note 1, supra.

404 I am one of them. See Louis MiChael Seidman, On Constitutional Disobedience (2013). See also Michael J. Klarman, Antifidelity, 70 S. CAL. L. REv. 381 (1997); Michael J. Klarman, What's So Great about Constitutionalism, 93 NW. L. ReV. 145 (1998).

405 See Douglas H. Ginsburg, Delegation Running Riot, 1 RegulATION 89 (1995). See generally, Symposium, The Constitution in Exile, 51 DUKE L. J. 1 (2001). 
question of what to do about it. Return to original constitutional understandings might, among other things permit the revival of overt gender discrimination, ${ }^{406}$ and allow states to outlaw interracial marriage. ${ }^{407}$ A few diehards are prepared to accept this and more, but even most originalists find these outcomes too much to swallow. Accordingly, they avoid these results with transparent dodges like reliance on stare decisis or on the same sort of tendentious, result-driven arguments that they (rightly) accuse their opponents of using. In obvious ways, the use of both techniques supports the skeptical position.

Other conservative judges and academics are much more straight forward in endorsing aspects of constitutional skepticism. For example, natural law advocates like Hadley Arkes reject the proposition that we should rely on the Constitution if it is not supported by sound moral principles. ${ }^{408}$ Richard Posner, perhaps the best known lower federal court judge in the country and once the darling of conservatives, maintains that the United States Supreme Court is political in its orientation and denies that constitutional law, at least as conventionally understood, explains or justifies what judges do. ${ }^{409} \mathrm{~J}$. Harvie Wilkinson, another distinguished conservative jurist, purports to disagree with Posner but apparently shares his view that no theory of constitutional law is satisfactory. ${ }^{410}$ In a series of important works, Adrian Vermeule has advanced sophisticated arguments against use of the conventional tools of constitutional adjudication. ${ }^{411}$

406 See Ruth Bader Ginsburg, Sexual Equality under the Fourteenth and Equal Rights Amendments, 1979 WASH. U. L. Q. 161, 161-63 ("Boldly dynamic interpretation, departing radically from the original understanding is required to tie the fourteenth amendment's equal protection clause to a command that government treat men and women as individuals equal in rights, responsibilities, and opportunities.") But see Steven G. Calabresi \& Julia Rickert, Originalism and Sex Discrimination, 90 TEX. L. REV. 1 (2011).

407 See, e.g., Ronald Turner, Were Separate-But-Equal and Antimiscegnation Laws Constitutional? Applying Scalian Traditionalism to Brown and Loving, 40 SAN DIEGO L. REV. 285 (2003).

408 See HADLEY ARKES, Beyond the Constitution (1990).

409 See, e.g., Richard A. Posner, Foreword: A Political Court, 119 HARV. L. REV. 31 (2005).

410 See J. Harvie Wilkinson, Cosmic Constitutional Theory: Why Americans Are Losing Their Inalienable Right to SeLF-GovernANCE (2012).

411 See, e.g., Eric Posner \& Adrian Vermeule, Originalism and Emergencies: A Reply to Lawson, 87 B.U. L. ReV. 313 (2007) (arguing against reliance on originalism to determine scope of executive power in emergencies); Adrian 
Scholars on the left are, if anything, even more receptive to skeptical positions. For example, in academics associated with Critical Legal Studies, including Mark Tushnet, ${ }^{412}$ Duncan Kennedy, ${ }^{413}$ and Peter Gabel ${ }^{414}$ have attacked the very concept of constitutional rights. More recently, Tushnet, ${ }^{415}$ together with Larry Kramer ${ }^{416}$ and Jeremy Waldron ${ }^{417}$ have argued against the assumption that judges should enforce the Constitution. Tushnet has coupled this attack with an endorsement of a "thin" ${ }^{418}$ some would say anorexic ${ }^{419}$ - constitution limited to the ideals expressed in the Constitution's preamble and the Bill of Rights. In two important books, ${ }^{420}$ Sanford Levinson has written in detail about the Constitution's many deficiencies and called for a new constitutional convention to correct them. Bruce Ackerman ${ }^{421}$ and his colleague Akhil Amar $^{422}$ have argued that the Constitution can be and has been changed outside the formal amendment process. Mark Graber ${ }^{423}$ and J.M. Balkin ${ }^{424}$ have written more generally about the problem of "constitutional evil." Girardeau Spann has argued that constitutional judicial review systematically harms racial minorities, ${ }^{425}$ and Gary Peller has attacked the standard

Vermeule, Foreword: System Effects and the Constitution, 123 HARV. L. ReV. 4 (2008) (arguing that even if originalism is first best approach, it should not be used in real, second-best world).

412 Mark V. Tushnet, An Essay on Rights, 62 TEX. L. ReV. 1363 (1984).

413 Duncan Kennedy, "The Critique of Rights in Critical Legal Studies" in LEGALISM/LefT CRITIQUE (Wendy Brown \& Janet Halley eds., 2002).

414 Peter Gabel, The Phenomenology of Rights Consciousness and the Pact of the Withdrawn Selves, 62 TEX. L. REV. 1563 (1984).

415 Mark V. Tushnet, TAKIng the Constitution AWAY From the Courts (1999).

416 Larry D. Kramer, The People Themselves: Popular Constitutionalism and Judicial Review (2004).

417 See. e.g., Jeremy Waldron, The Core of the Case against Judicial Review, 115 YALE L. J. 1346 (2006); Jeremy Waldron, "Judicial Power and Popular Sovereignty'in MARBURY VERSUS MADISON: DOCUMENTS AND COMMENTARY 181 (Mark A. Graber \& Michael Perhac eds., 2002).

418 See MARK V. TUSHNET, note 415S, supra, at 11.

419 See Saikrishna B. Prakash, America's Aristocracy, 109 YALE L. J. 541, 553 (1999).

420 SANFord LEVINSON, FRAMED: AMERICA's FIFTY-ONE Constitutions AND THE CRISIS OF GOVERNANCE (2012); SANFORD LeVinson, OUR Undemocratic Constitution: Where the Constitution Goes Wrong (AND HoW We the People CAN Correct IT (2006).

421 Bruce ACKerman, We the People (1991).

422 Akhil R. Amar, Philadelphia Revisited: Amendment the Constitution Outside Article V, 55 U. CHI. L. ReV. 1043 (1988).

423 Mark A. Graber, Dred Scott and the Problem of Constitutional EVIL (2006).

424 J.M. Balkin, Agreements with Hell and Other Objects of Our Faith, 65 FORD. L. REV. 1703 (1997).

425 Girardeau A. Spann, Race Against the Court: Supreme Court AND Minorities in CONTEMPORARy America (1993). 
integrationist view, which dominates constitutional treatments of race. ${ }^{426}$ Their colleague, Robin West, has maintained that constitutionalism, especially when associated with judicial review, stunts moral imagination. ${ }^{427}$

Finally, scholars not closely associated with either the left or the right have seized on a variety of skeptical arguments. For example, Michael Klarman ${ }^{428}$ and Gerald Rosenberg ${ }^{429}$ have both shown that judicial enforcement of constitutional text has been relatively unimportant in producing social change. Barry Friedman has demonstrated that constitutional decisions by judges usually conform to public opinion. ${ }^{430}$ Daryl Levinson has argued that constitutional obligation plays an unimportant role in preventing political actors from abusing their power. ${ }^{431}$ Cass Sunstein has defended a "judicial minimalism" grounded in a deep distrust of constitutional litigation as a means of achieving broad scale social justice. $^{432}$

In short, reports of the death of constitutional skepticism are greatly exaggerated. Of course, every generation refashions skeptical arguments to suit its own needs, just as every generation has its own version of constitutionalism. The skepticism of early twenty-first century America is not the same as the skepticism of the Founders, or of the antebellum period, or of the Progressives. Yet amidst all of the celebration of the American Constitution and denigration of its critics, something identifiable as a skeptical tradition connected to crucial political events throughout our history continues to survive and flourish.

\section{Disaggregating and Reintegrating the Varieties of Skepticism}

\footnotetext{
426 Gary Peller, Critical Race Consciousness: Reconsidering American Ideologies of RaCial Justice (2011).

427 See, e.g., Robin L. West, Constitutional Scepticism, 72 B.U.L. REV. 765 (1992).

428 Michael J. Klarman, Rethinking the Civil Rights and Civil Liberties Revolutions, 82 VA. L. REV. 1 (1996).

429 Gerald N. Rosenberg, The Hollow Hope: Can Courts Bring about Social Change? (1991).

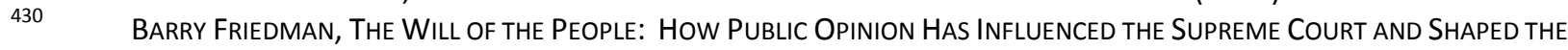
MEANING OF THE CONSTITUTION (2009).

431 Daryl J. Levinson, Parchment and Politics: The Positive Puzzle of Constitutional Commitment, 124 HARV. L. REV. 657 (2011).

432 Cass R. Sunstein, Foreword: Leaving Things Undecided, 110 HARV. L. REV. 4 (1996).
} 
As the last Part demonstrates, at one time or another, a large number of scholars and politicians have endorsed constitutional skepticism. It has been a feature of some of the most important political movements of our history and has fueled arguments of both the right and the left. It might nonetheless be thought that this history exaggerates the influence of the skeptical argument because there is not really a single skeptical position, but, instead, a variety of quite different views misleadingly grouped under a single rubric.

One response to this criticism is to point out that the mainstream constitutional tradition is similarly fragmented. People who label themselves constitutionalists also believe a wide variety of different things, not all of which are consistent with each other. Respect for constitutional text (interpreted in a variety of inconsistent ways ${ }^{433}$ ), for judicial decisions whether faithful to text or not, ${ }^{434}$ for various versions of tradition, ${ }^{435}$ and for philosophical understandings, ${ }^{436}$ all pass for constitutional commitment. ${ }^{437}$ If we do not expect unity from constitutionalism's defenders, there is no reason to expect unity from its opponents.

Perhaps this is answer enough, but in this Part, I nonetheless explore the question whether the various skeptical arguments I have discussed in Part I have a common core. In Section A, I separate out the various strands of skepticism. Section B argues that that these strands do indeed have something in common and that they are connected to a deeply American belief in the possibility of right answers to moral and political questions.

$433 \quad$ Compare, e.g., Randy E. Barnett, An Originalism for Nonoriginalists, 45 Loy. L. REV. 611, (1999) (original public meaning) with Larry Alexander \& Saikrishna Krakash, "Is that English You're Speaking?" Why Intent Free Interpretation Is an Impossibility, 41 SAN DIEGO L. REV. 967 (2004) (original intent of speaker).

$434 \quad$ See. e.g, Larry Alexander \& Frederick Schauer, On Extrajudicial Constitutional Interpretation, 110 HARV. L. REV. 1359 (1997) (arguing for judicial finality).

$435 \quad$ Compare Michael H. v. Gerald D, 491 U.S. 110, 127 n.6 (1989) (arguing for use of tradition at "the most specific level at which the relevant tradition protecting, or denying protection to, the asserted right can be identified") with id. at 138 (Brennan, J., dissenting) (arguing for a broader conception of tradition.)

436 See, e.g., R. M. DWORKIN, LAW's EMPIRE(1986) (arguing for interpretations based on the philosophically best reading of the legal materials).

437 Cf. Thomas B. Colby \& Peter J. Smith, Living Originalism, 59 DuKE L. J. 239, 239 (2009) (arguing that "originalism is not a single, coherent, unified theory of constitutional interpretation, but is rather a disparate collection of distinct constitutional theories that share little more than a misleading reliance on a common label.") 


\section{A. Varieties of Skepticism}

In this section, I attempt to disentangle the various strands of skepticism while simultaneously offering the beginnings of a defense for each variety.

1. Constitutional Evil. The starting point for most skeptical arguments is a perceived gap between constitutional commands on the one hand and some other source of normative authority on the other. If a constitution, or a particular provision in a constitution, is evil, why should anyone obey it? ${ }^{438}$ The argument that one shouldn't was made most persuasively and directly by antebellum abolitionists. If constitutional protection for slavery was indeed a pact with the devil, why adhere to it? ?39 $^{439}$

A believer in constitutionalism might respond that skeptics should not be so doctrinaire. I might believe that a particular provision is evil but still choose to obey on the grounds that most other people believe it to be good. After all, how can I be so sure that I am right and they are wrong? ${ }^{440}$

Unfortunately, though, normative humility does not solve the problem of constitutional evil. Of course, people should be open-minded and wonder about the rightness of their own judgments when many others disagree. Initial judgments should be corrected to account for these and other facts. But the question remains: why should I obey a constitutional provision when it conflicts with my corrected judgment?

At first, one might think that constitutional evil poses a problem only if the constitution is in fact evil. If the constitution is not evil, or if it is more good than evil, or if it is more good than the likely

438 Of course, one answer is that the Constitution, taken as a whole, is better than any likely alternative. This argument was successfully pressed during the ratification debates by Federalists, who managed to frame the issue as a choice between an unamended constitution and the status quo. See note 3 , supra. But the answer is unsatisfying if one believes that particular evil provisions can be excised without jeopardizing the overall agreement or if one believes that the evil of some provisions outweighs the good done by others.

${ }_{439} \quad$ See $\mathrm{pp} \mathrm{xx}-\mathrm{xx}$, supra.

440 Cf. Michael W. McConnell, The Importance of Humility in Judicial Review: A Comment on Ronald Dworkin's "Moral Reading" of the Constitution, 65 FORDHAM L. REV. 1269, 1292 (1997). 
alternatives, then, one might think, the problem does not arise. It turns out, though, that at least on the conceptual level, constitutional evil creates a problem for even good constitutions.

The problem reemerges when one focuses on what it means to "obey" a constitution. Acceding to a constitutional provision because of accidental overlap between the provision and a binding norm is not obedience. No one would say that Orthodox Jews are obeying Koranic law when they refuse to eat pork or that Americans who abstain from armed robbery are obeying the laws of Finland, even if Finland asserts universal jurisdiction for its laws. In order for authentic obedience to take hold, the command in question must make a difference. If the command does no work - if one would engage in the same conduct whether or not the command existed - then the need for obedience simply does not arise.

It follows that constitutional evil is a problem for even the good constitution. It is true that if one believes that a constitution is good, one need not lose sleep over whether to follow its terms. But following those terms is only contingent. If an independent belief in the goodness of constitutional provisions is the only ground that supports a duty to comply, then the duty will disappear whenever one disagrees with what the constitution says. Moreover, even if a lucky individual happens to live in a jurisdiction where there is no gap between a constitution and other commitments, there remains the difficulty of what stance to take toward others who disagree with constitutional provisions. How can I in good faith insist that you must obey provisions that you find odious when my own compliance is contingent on my substantive agreement with the provisions?

For similar reasons, this understanding of obedience undermines the common observation that, despite some bad provisions, the good in the United States Constitution outweighs the bad. Perhaps it does, but that observation does not explain why we should not adhere to the good provisions while ignoring the bad. Maybe selective obedience is impossible because the Constitution is somehow a package deal. Still, acceptance of the package is again contingent on a belief based on nonconstitutional norms that the good outweighs the bad. Following a constitution in these circumstances rests not on 
obedience, but on a contingent overlap between constitutional commands, taken as a whole, and one's nonconstitutional conception of the good. A test for authentic obedience arises only when the balance is struck the other way. People who reject constitutional skepticism must explain why in these circumstances, we should adhere to constitutional commands.

A more promising solution plays off the similarity between the problem of constitutional obligation and the more general problem of political obligation. Of course, constitutions can be evil and, obviously, when they are, political theory faces difficult dilemmas. But ordinary law can also be evil, and theorists over several millennia have struggled with the problem of general political obligation. It comes as no surprise that an anarchist who believes that all these efforts have been unsuccessful will also be a constitutional skeptic. But most people are not anarchists. The challenge for nonanarchist who are also constitutional skeptics is to explain why constitutional obligation is especially problematic. Put differently, they must explain why constitutions are different from ordinary law. The next section provides one answer to that challenge.

2. The dead hand problem. One difference between constitutions and ordinary law is that constitutions tend to be more entrenched against change. Perhaps comparative entrenchment is not a conceptually necessary feature of constitutions, but it is at least empirically associated with them. As it happens, the association is especially important in the United States, which has the most entrenched national constitution in the world. ${ }^{441}$

Entrenchment raises skeptical doubts about why a society should feel bound by decisions made long ago. Even if ordinary laws should be obeyed, why obey judgments that are relatively immune to change? This version of skepticism consists of two, related worries. First, constitutions that are old are

\footnotetext{
${ }^{441}$ Article $V$ makes the requirement of equal suffrage in the Senate - the requirement, in other words that both California and Wyoming have two senators - legally unamendable. There is no legal barrier to amending the rest of the document, but the requirement of approval by either two thirds of each House or by a constitutional convention followed, in either case, by approval of three fourths of the states often makes amendment a practical impossibility.
} 
bound to have provisions that fit poorly with current social and technological realities. It is far from clear that decisions about, say, privacy, press freedoms, or guns made hundreds of years ago in a small, mostly rural republic that had never heard of television, the internet, or semiautomatic weapons also make sense today. Progressives, writing in the wake of the industrial revolution repeatedly pressed a version of this argument, ${ }^{442}$ as did Franklin Roosevelt when he complained that the Supreme Court was enforcing a "horse and buggy" version of the Constitution. ${ }^{443}$

Second, entrenchment raises questions about democratic legitimacy. Why should people long dead "outvote" people alive now who should have the right live their own lives? As we have seen, this was the problem that preoccupied, Hume, ${ }^{444}$ Paine, ${ }^{445}$ and, especially, Jefferson. ${ }^{446}$ Constitutions are often defended as acts of political autonomy. Skeptics argue that the autonomy of dead generations comes at the price of subservience of living generations.

One response to both branches of the argument is that entrenchment derives not from ancient command but from present choice. Modern Americans are not forced, kicking and screaming as it were, to follow constitutional commands. After all, the Framers have no actual power over us. We obey the Constitution because we have made a current choice to obey.

On reflection, however, this response dissolves into arguments that have already been addressed. If one means by it that Americans today obey the Constitution only because they believe that it is substantively good, then, for reasons discussed above, they are not engaged in authentic obedience. Perhaps instead, the point is, that, whether rightly or wrongly, modern Americans simply think that they have a duty to accede to what the Framers wrote even when they disagree with it. But if

442 See,e.g., Robert M. La Follette, “Introduction” in GILBERT E. RoE, Our Judicial Oligarchy vi-vii (1912)

(attacking courts for "fossilized precedent" and "detachment from the vital, living facts of the present day.")

$443 \quad$ See "FDR and the Supreme Court - FDR Press Conference, May 31, 1935 available at

http://newdeal.feri.org/court/fdr5 31 35.htm (arguing that "[t]he country was in the horse-and-buggy age when [the commerce clause of the U.S. Constitution] was written.")

$444 \quad$ See P. $x x$, supra.

445 See P. $\mathrm{xx}$, supra.

$446 \quad$ See $\mathrm{pp} \mathrm{xx}-\mathrm{xx}$, supra. 
this is all the argument amounts to, then the position engages rather than refutes the skeptical tradition. Skeptics will respond that before making a decision to blindly obey, Americans need to think about the skeptical arguments against doing so. It makes no sense to short circuit a discussion about skepticism with the bare assertion that people presently reject it.

Finally, a constitutionalist might respond that Americans who disagree with some constitutional provisions nonetheless feel bound to them because political community must exist over time, and our constitutional tradition defines who we are as a nation. ${ }^{447}$ But this assertion merely raises the central issue to which this Article is addressed. Assuming arguendo that the point about political communities is correct, we nonetheless need to decide how to define our political tradition. The burden of my argument is that skepticism offers an attractive alternative to the standard story.

It turns out, then, that entrenchment poses a serious problem for constitutionalists and provides a reason why people who accept general political obligation might nonetheless reject constitutional obligation. Of course, it is true that ordinary statutes are also entrenched to some extent. No sane government could operate under a system where laws expired as soon as they were enacted. The need for planning, settlement, and certainty have some claim upon us, and it would be wildly inefficient - in fact, impossible - to constantly rethink every political decision we have made.

But this fact demonstrates only that the distinction between statutes and constitutions is a matter of degree rather than kind. So long as constitutions are relatively entrenched when compared to ordinary law, then, skeptics insist, constitutionalists must justify the extra margin of entrenchment. Put differently, our ordinary laws should strike the right balance between stability and change. Constitutionalists must explain why the ordinary balance is inappropriate in the case of constitutional provisions. 
3. Indeterminacy. Of course, entrenchment would hardly matter if the entrenched provisions did not bind us to anything. One way to understand the claims made by eighteenth century American constitutionalists $^{448}$ and by Franklin Roosevelt almost two hundred years later ${ }^{449}$ is that the constitutional commands are deeply indeterminate. Perhaps they set out fixed ideals or general goals, but the ideals and goals are so vague that they can only structure discussions, not dictate outcomes.

The indeterminacy point is double edged. On the one hand, American Legal Realists utilized it as a skeptical cudgel against rule-of-law conservatives. They argued that the decisions of Lochner era judges were not a scientific and logical explication of clear rules. Instead, they were manifestations of regressive political choices that, because they could not be honestly defended, were obfuscated by legal rhetoric. ${ }^{450}$ Critical Legal Studies has made the same point in our own time. ${ }^{451}$

On the other hand, indeterminacy also provides a kind of defense against skeptical accusations. How can the Constitution possibly be evil if it allows us to do whatever we want? In what sense are we bound by the Framers' dead hand if their language is infinitely plastic?

Skeptics can offer a layered response to constitutionalist cooptation of the indeterminacy argument. First, some provisions of the Constitution are not indeterminate. The text is clear that the President does not have a life-time appointment and that measures passed by the Russian Parliament are not thereby the laws of the United States. These particular examples of textual clarity hardly matter, but other provisions - for example entrenching representation in the Senate that is wildly disproportionate or allowing a President to be elected while losing the popular vote - are quite consequential.

\footnotetext{
$448 \quad$ See pp xx-xx, supra.

449 See pp xx-xx, supra.

450 See, e.g., Karl N. Llewellyn Some Realism about Realism - Responding to Dean Pound, 44 HARV. L. REV. 1222,1237 (1931) (identifying legal realism with "distrust of traditional legal rules . . insofar as they purport to describe what . . courts . . . are actually doing," and exploration of "the theory of rationalization for what light it can give to the study of opinions.")

451 See, e.g., Mark V. Tushnet, Following the Rules Laid Down: A Critique of Interpretivism and Neutral Principles, 96 HARV. L. REV. 781 (1983) (defending indeterminacy thesis).
} 
A thoroughgoing believer in the indeterminacy thesis might deny that even these results are inevitable. A clever enough lawyer, she will insist, can get around any constitutional language. Perhaps, for example, equal protection principles as applied to the federal government through the fifth amendment's due process clause ${ }^{452}$ outlaw both our system of Senate representation and the Electoral College. ${ }^{453}$

This point is undoubtedly correct as a conceptual matter. All language is conventional. Given sufficient change in cultural assumptions, the meaning of words can change dramatically. But although accurate as far as it goes, the point ignores the fact that language has undeniable meaning once one specifies a surrounding culture. It is simply a fact that despite theoretical linguistic underspecification, people effortless understand which interpretations make sense and which do not. I would not write this article but for the hope that others will understand what I mean, and judges and other decision makers unquestionably sometimes have the internal experience of feeling bound by legal language. ${ }^{454}$ The fact that these understandings are not built into the internal structure of language -- and even the fact that they may be conditioned by exercises of social power -- does not undermine this point. For whatever reason, words sometimes bridge the gap between persons.

All this suggests that the indeterminacy thesis, at least in its extreme and global form, is incorrect. But if the thesis is wrong, how can it be part of a skeptical critique? Here we come to the second layer of the skeptical argument. Of course, some constitutional language is relatively determinate, but other language is quite indeterminate. At least given today's culture, we think we know what it means when the Constitution says that each state shall be represented by two senators,

452 See, e.g., Bolling v. Sharpe, 347 U.S. 497 (1954) (applying equal protection provisions to the federal government).

$453 \quad$ But cf. Reynolds v. Sims, 377 U.S. 533, 574 (1964) (distinguishing malapportionment in the Houses of Congress on the ground that the malapportionment "is one ingrained in our Constitution, as part of the law of the land. It is one conceived out of compromise and concession indispensable to the establishment of our federal republic.")

454 Cf. Duncan Kennedy, A Critique of Adjudication: Fin de SiÈCle (1997). 
but it is anybody's guess what constitutes "equal protection of the laws" or a "Republican form of Government." ${ }^{455}$ The problem, then, is this: to the extent that Constitutional language is determinate, we confront the constitutional evil and dead hand problems. To the extent that it is indeterminate, we confront the problem of who will have the final authority to declare its meaning.

Moreover, whatever body is given this authority is bound to exaggerate the size of the determinacy domain. This tendency is built into the very structure of constitutional obligation. Because the legitimacy of the decision maker rests on constitutional obligation, the decision maker cannot admit that the decisions are based on nonconstitutional considerations. The result is a kind of systematic misrepresentation. Just as the Legal Realists claimed, people who believe in constitutional obligation are tricked into acceding to commands that are not really dictated by the Constitution.

4. Judicial Supremacy. On the conventional view, Justices of the United States Supreme Court have final interpretive authority. ${ }^{456}$ Many skeptics throughout our history, including Jefferson, Lincoln, and Theodore and Franklin Roosevelt, have rejected this axiom. ${ }^{457}$ Oddly, though, it takes some work to explain why the axiom is part of the skeptical tradition at all.

There are two reasons why the case against judicial supremacy fits uneasily within the skeptical tradition. First, whatever its other problems, judicial supremacy does not contribute to the dead hand or constitutional evil difficulties. If judges did not enforce the Constitution, and if we are not to give up altogether on constitutional obligation, then constitutional commands would have to be enforced by some other institution. But whatever institution did the enforcing would be obligated to privilege opinions held by people long dead over opinions held by Americans today and, so, would implicate the dead hand problem. If these provisions were evil, then people alive today would still be confronted with

\footnotetext{
$455 \quad$ This distinction roughly parallels the distinction many "new originalists" make between constitutional interpretation and constitutional construction. See, e.g., Lawrence B. Solum, The Interpretation-Construction Distinction, 27 CONST. COMM. 95 (2010).

$456 \quad$ See.e.g, Cooper v. Aaron, 358 U.S. 1 (1958) (asserting Supreme Court's final interpretive authority). $457 \quad$ See pp xx, supra.
} 
the daunting question why they should respect those provisions rather than their present, all-thingsconsidered judgment.

Second, as discussed above, ${ }^{458}$ there is a sense in which judicial supremacy is at war with constitutionalism rather than with constitutional skepticism. Judicial supremacy privileges the dictates of judges over constitutional commands. Put differently, when judges get it wrong, judicial supremacy mandates constitutional disobedience.

The attack on judicial supremacy can nonetheless be formulated in a fashion that makes it an important part of the skeptical tradition. It is again useful to distinguish between constitutional provisions with determinate and indeterminate meaning.

Suppose first that the meaning of a constitutional provision is sufficiently indeterminate that it fails to resolve a contested case. Then, as explained above, when judges have final authority, their decision must be based on something other than constitutional law. At first, it might seem strange for opponents of constitutional obligation to complain about this fact. After all, their core objection is to the privileging of constitutional text. The problem, though, is that judges regularly claim that they are not actually exercising power, but are instead merely doing what the Constitution requires. To the extent that the public believes that this is so, their decisions have more prestige than they deserve. Moreover, even if the public does not believe a word of it, the decisions are systematically less subject to a democratic check than those of other officials.

One might suppose that these problems do not arise if the text is determinate. Even if it is, though, judges might simply refuse to do what the text requires. When this happens, we run into the problem that worried Hobbes and Madison. ${ }^{459}$ The central promise of constitutionalism is that agreement on a set of principles, usually incorporated in a constitutional text, can settle otherwise destabilizing disagreement at the political level. Unfortunately, though, as soon as people begin to 
complain that others are ignoring constitutional text, this promise can no longer be kept. Obviously, settlement will not be achieved if everyone can insist on her own version of the Constitution. Hence, the need for an authoritative interpreter. But if the interpreter is in fact authoritative, then we are not committed to constitutional obedience after all, but instead to the hierarchical order produced by obedience to the dictates of the interpreter - dictates that might actually violate the Constitution.

5. Realizability. The dilemma of judicial supremacy leads directly to the final strand of constitutional skepticism - the problem of implementation. Even if constitutions are good, and even they are somehow democratically legitimate, how are they to be enforced? Social stability demands public institutions powerful enough to coerce recalcitrant individuals who want to reject collective judgments. But once empowered, how are these institutions to be restrained? To paraphrase Madison, public spirited officials require no constitutional constraints, while officials who are more willful and selfinterested are unlikely to respond to them. ${ }^{460}$ In either case, it seems doubtful that constitutional obligation makes much of a difference.

One might suppose that this worry is refuted by facts on the ground. We do not see American Presidents regularly jailing their political opponents or cancelling elections. Congress does not pass statutes that establish an official religion, and the Supreme Court does not hold people in contempt when they criticize its opinions.

But this overlap between official behavior and constitutional commands does not demonstrate causation. To prove that constitutions are effective, constitutionalists must show not just that the behavior of public officials corresponds to what constitutions require, but also that the officials behave this way because of the constitutional requirement. Put differently, they would have to show that

460 Cf. Federalist No. 51 in THE FEDERALIST, note 90 supra, at 269 ("If men were angels, no government would be necessary. If angels were to govern men, neither external nor internal controuls on government would be necessary.") 
officials who had the power and the motive to do something that the Constitution prohibits regularly abstain from this behavior just because of the constitutional prohibition. ${ }^{461}$

In fact, there are many constraints on public officials that have nothing to do with constitutional obligation. Consider all the things that the Constitution permits but that officials nonetheless abstain from doing. Congress does not refuse to appropriate money funding the President's press secretary or reduce the size of the Supreme Court to two justices. The President does not threaten to veto every bill that Congress enacts unless he gets his way. Supreme Court justices do not campaign for political candidates and have, on occasion, made extraordinary efforts not interfere with a sitting President's domestic programs. ${ }^{462}$ These actions are not prevented by constitutional obedience because the Constitution does not prohibit them. (In fact, in the case of judicial efforts to avoid confrontation with a President, the Court's actions may be in tension with constitutional obligation as the justices themselves understand it). Instead, the restraint comes from some combination of political calculation, habit, moral inhibition, and fear of retaliation. Why should we suppose that the same forces would not prevent other kinds of overreaching even if there were no Constitution?

In recent years, inhibitions against extraordinary measures of this kind have begun to erode as a more Manichean conception of American politics takes hold. ${ }^{463}$ Perhaps the inhibitions will eventually collapse completely. If they do, though, it is foolish to suppose that constitutional text will save us. Ultimately, a political community requires forbearance, compromise, empathic connection, and a sense of a shared fate to survive. Once these disappear, ancient words subject to radically different interpretations and with doubtful connection to our present circumstances are unlike to save it.

461 This point is elaborated on at length in Daryl J. Levinson, Parchment and Politics: The Positive Puzzle of Constitutional Commitment, note 431, supra.

462 See, e.g., National Federation of Independent Business v. Sebelius, 132 S. Ct. 3566, 2594 (2012) (Roberts, C.J.) ("The Government asks us to interpret the [health care]mandate as imposing a tax, if it would otherwise violate the Constitution. Granting the Act the full measure of deference owed to federal statutes, it can be so read (....")

See Mark V. Tushnet, Constitutional Hardball, 37 J. MARSH. L. ReV. 523 (2004). 


\section{B. The Common Core of Constitutional Skepticism}

In the previous section, I arranged the various skeptical arguments in a fashion designed to demonstrate an overlap between them. At the very least, the varieties of skepticism share a family resemblance. In this section, I hope to go beyond this claim and demonstrate that they also share a common core. My strategy is to start by exploring the relationship between constitutional skepticism and a more global skepticism about the possibility of right answers to political and moral problems. Although not logically required, as a contingent historical fact, American constitutional skepticism has often been associated with a rejection of global skepticism. That linkage, in turn, unifies the various strands of skeptical argument and connects them to American optimism about the possibility of moral progress.

1. Constitutional and global skepticism. Global moral and political skepticism takes a variety of different forms. Some skeptics doubt the possibility of objective moral truth and think of moral assertions as having the same status as claims about tastes and wants. Others, who concede at least arguendo, the possibility of moral truth doubt the possibility of reliably discovering it. Still other skeptics think that moral truths lack the kind of uncontroversial foundation that would allow us to discuss them and come to agreement on what they are. ${ }^{464}$

Whatever form this global skepticism takes, there is an apparent link between it and constitutional skepticism. After all, if there is no good reason to believe that any action is morally required, how can one believe that constitutional obedience is so required? ${ }^{465}$

People who insist on this linkage are not making a logical mistake. Viewed from a certain angle, there is indeed an association between moral and constitutional skepticism. But although the

\footnotetext{
$464 \quad$ This is not the place for a sophisticated exploration of the various skeptical positions. For a useful taxonomy, see Michael S. Moore, Moral Reality Revisited, 90 MICH. L. REV. 2424, 2433-36. (1992) 465 Cf. Amy Gutman, "How Liberal Is Democracy" in LiBERALISM ReConsidered Xx (Doublas MacLean \& Claudia Mills, eds. 1983) (arguing that moral skepticism cannot support democracy because a moral skeptic must be skeptical of the worth of democracy).
} 
association is a permissible one, it is not compelled. It is also possible to base constitutional skepticism on a rejection of global skepticism.

Two of Oliver Wendell Holmes most famous dissents illustrate how global skepticism can point in opposite directions. Holmes' traumatic experiences during the Civil War left him with a deep suspicion of claims to immutable moral truth. ${ }^{466}$ In his dissenting opinion in Lochner v. New York, this skepticism led him to reject the effort to constitutionalize freedom of contract. Claiming that "[g]eneral propositions do not decide concrete cases," and that legal decisions "will depend on a judgment or intuition more subtle than any articulate major premise," he doubted that one could reason to this constitutional outcome. Because the constitution was "made for people of fundamentally differing views," judges should be slow to "prevent the natural outcome of a dominant opinion." ${ }^{467}$ Yet in his dissent in Abrams v. United States, this same skepticism led Holmes to constitutionalize protection for speech freedoms. Just because "time has upset many fighting faiths," therefore "the ultimate good desired is better reached by free trade in ideas." ${ }^{468}$

John Dewey's evolving ideas about constitutionalism demonstrate the same point. Dewey's adherence to Pragmatism left him skeptical about permanent, noninstrumental conceptions of truth. Early in his career, this skepticism led him to denigrate constitutional protection for individual rights. ${ }^{469}$

466 See, e.g., G. EdWARd White, Justice Oliver Wendell Holmes: LAW AND THE INNER SelF Xx (1995) Thomas Corcoran, who served as Holmes' secretary, quotes Holmes as saying that "the only other guy who really knew what he was here for was [Chief Justice Edward] White. When Corcoran asked for an explanation, Holmes replied:

I fought in The Civil War on the Union side. White fought on the Confederate side. He and I knew that the Court should never lend status to any faction which might push us toward another conflict. My style was never to write anything except about the particular case under consideration. No generalization, no philosophizing. I wrote so short you couldn't understand it and White wrote so long that you couldn't understand it.

John S. Monagan, “Pawtucket Irishman and Magnificent Yankee, NEW York STATE BAR JournAL, FEB, 1987 , AT 16.

Lochner v. New York, 195 U.S. 45, 65 (1905) (Holmes, J., dissenting).

Abrams v. United States, 250 U.S. 616, 630 (1919)

See pp xx-xx, supra. 
After World War I, the same skepticism about deep moral foundations caused him to celebrate civil liberties and the openness of American society. ${ }^{470}$

The writings of Dewey and Holmes demonstrate that there is no necessary association between global and constitutional skepticism. Global skepticism might cause one to be skeptical about constitutional obligation, but it also might cause one to substitute "local knowledge" or norms within a conventional practice for moral foundations. Put differently, if there is no foundational truth that all must accept, then all we are left with is norms for particular communities like those contained in a national constitutional. Conversely, moral realism is compatible with the view that there is a foundational, moral obligation to obey a constitutional text, but it might also cause one to disobey the text if it is thought that the text was inconsistent with foundational moral obligations.

As contingent, historical fact, many constitutionalists have been moral skeptics of one kind or another, and many constitutional skeptics have believed in the possibility of moral truth. Consider first the global skeptics who endorse constitutionalism. In his famous article defending constitutional originalism, ${ }^{471}$ Robert Bork began with the premise that moral philosophy could not resolve important issues of public policy. On his view, there was "no principled way to prefer any claimed human value to any other" or to "decide that one man's gratifications are more deserving of respect than another's or that one form of gratification is more worthy than another." ${ }^{472}$ A person insisting on the right to sexual intimacy with her spouse had the same status as an electric company insisting on providing low cost power by polluting the air, he claimed. It was just because there was no way to make these differentiations, Bork insisted, that judges acted illegitimately when they tried to discover fundamental moral values and were obligated instead to enforce "neutral" constitutional text. ${ }^{473}$

470 See, e.g., EdWARd A. PURCELL, JR, THE CRISIS Of DeMOCRATIC THEORY XX (1973) (describing Dewey's post-war position).

$471 \quad$ Robert H. Bork, Neutral Principles and Some First Amendment Problems, 47 IND. L. J. 1 (1971).

$472 \quad$ Id., at 11.

473 Id. 
Bork's contemporary, John Hart Ely developed a very different but similarly influential version of constitutionalism. ${ }^{474}$ Whereas Bork emphasized constitutional text, Ely recognized the indeterminacy of text alone and attempted to fill the lacuna by reference to the overall spirit and aims of the Constitution. In his view, the Constitution was mostly about fair procedures. Courts acted appropriately when they read the document to require such procedures, but not when they read into it their own moral conceptions. ${ }^{475}$ Strikingly, although his conclusions are very different, Ely's analysis began precisely where Bork's does. He wrote that

If there is such a thing as natural law, and if it can be discovered, it would be folly ... to ignore it as a source of constitutional values. It's not nice to fool Mother Nature, and even Congress and the President shouldn't be allowed to do so. We know it won't work, though. The idea is a discredited one in our own society, and for good reason. " $[A]$ ll theories of natural law have a singular vagueness which is both an advantage and disadvantage in the application of the theories." The advantage, one gathers, is that you can invoke natural law to support anything you want. The disadvantage is that everybody understands that. ${ }^{476}$

Once again, it is just because argument about natural law solves nothing that, on Ely's view, we should instead resolve our differences by reference to the Constitution.

Still a third highly influential version of constitutionalism, John Rawls theory of political liberalism, is similarly grounded. ${ }^{477}$ Rawls did not attack moral truth per se, but he despaired of the ability of people in a diverse society to have reasoned discussions of what he called "comprehensive doctrines." ${ }^{478}$ If we are to have civic peace rooted in justice, he claimed, we must forego moral discussions of this sort and rely instead on an overlapping consensus, which he associated with standard, western constitutionalism. ${ }^{479}$

\footnotetext{
474 See JOHn HART ELY, DEMOCRACY AND DISTRUST (1980).

$475 \quad$ Id., at $x x$

$476 \quad$ Id., at $x x$

477 JOHN RAWLS, POLITICAL LIBERALISM (1996).

$478 \quad$ Id., at 242-43.

479 Id. ("[D]iscourse can seem shallow because it does not set out the most basic grounds on which we believe our view rests. .. . But it is only in this way, and by accepting that politics in a democratic society can never be guided by what we see as the whole truth, that we can . . . live politically with others in the light of reasons all might reasonably be expected to endorse.")
} 
Many constitutional skeptics have had a very different conception of moral truth and the possibilities for moral argument. As discussed above, most skepticism is rooted in the problem of constitutional evil, which, in turn, presupposes an ability to know and debate moral truth. The point is most obvious with regard to the antebellum abolitionists. Abolitionism was closely associated with the Second Great Awakening, the large-scale religious revival that gripped mid-nineteenth century America. ${ }^{480}$ Abolitionists infused their rhetoric with claims to moral truth. Garrison insisted that the Constitution was a "pact with the devil," ${ }^{481}$ and Julia Ward Howe was confident that the slaves would ultimately be freed because God's "truth is marching on."

Similarly, Jefferson, Lincoln and both Roosevelts had no qualms about using religious and moral rhetoric to support their programs when they were in tension with constitutional obligation. Jefferson had eccentric views about religion, but his defense of rebellion rested crucially on the "self evident truth" that all men were "endowed by their Creator with certain unalienable Rights." For years, while Lincoln temporized about slavery, he presented himself as a constitutionalist. But the Lincoln we remember is not the figure who in his first inaugural insisted on his constitutional obligation to protect slavery where it already existed. It is, instead, the Lincoln of the second inaugural who invoked not the Constitution, but the will of God to justify the bloody struggle against slavery:

The Almighty has His own purposes. "Woe unto the world because of offenses; for it must needs be that offenses come, but woe to that man by whom the offense cometh." If we shall suppose that American slavery is one of those offenses which, in the providence of God, must needs come, but which, having continued through His appointed time, He now wills to remove, and that He gives to both North and South this terrible war as the woe due to those by whom the offense came, shall we discern therein any departure from those divine attributes which the believers in a living God always ascribe to Him? Fondly do we hope, fervently do we pray, that this mighty scourge of war may speedily pass away. Yet, if God wills that it continue until all the wealth piled by the bondsman's two hundred and fifty years of unrequited toil shall be sunk, and until every drop of blood drawn with the lash shall be paid by another drawn with the sword, as 
was said three thousand years ago, so still it must be said "the judgments of the Lord are true and righteous altogether." 482

Theodore Roosevelt began his 1912 campaign with the claim that "We stand at Armageddon and we battle for the Lord." 483 In his first inaugural address, Franklin Roosevelt proclaimed that "The money changers have fled from their high seats in the temple of our civilization. We may now restore that temple to the ancient truths. The measure of the restoration lies in the extent to which we apply social values more noble than mere monetary profit." ${ }^{484}$

2. Skepticism's common core. This association of constitutional skepticism with claims to moral truth helps to link what might otherwise seem like disparate skeptical arguments. At bottom, constitutional skepticism rests on a rejection of the idea that constitutional text can bridge moral disagreement. People have an obligation to investigate moral truth for themselves, and, when they do so, they may discover that there is a gap between what the Constitution commands and moral obligation. Hence, the problem of constitutional evil. Because this obligation cannot be delegated to others, there is no just reason to give definitive weight to the mistaken views of prior generations. Hence, the "dead hand" problem. Nor can moral disagreement be bridged by open-ended constitutional language (the indeterminacy problem). Indeterminate language cannot provide settlement without a final interpreter (the judicial supremacy problem), and there is no more reason to accede to mistaken judgments by such an interpreter than to mistaken judgments by prior generations. The upshot is that constitutional law simply cannot make good on its promise to resolve disagreement and hold the country together (the realizability problem).

$482 \quad$ "Second Inaugural Address of Abraham Lincoln," available at http://avalon.law.yale.edu/19th_century/lincoln2.asp.

483 See "A Confession of Faith - 'We Stand at Armageddon, and we battle for the Lord" Progressive Party Convention - Chicago, Illinois August 6, 1912" available at http://www.theodoreroosevelt.com/images/research/speeches/trarmageddon.pdf $484 \quad$ See note 313 , supra. 
This is the negative side of constitutional skepticism. There is also a positive side. Skeptics claim not just that the Constitution is ineffective, but also that it is unnecessary. They have a deep faith that we can in fact make moral progress and come to moral agreement if only we listen carefully enough to each other and spend enough time and effort deliberating about what is to be done.

It is a mistake to suppose that belief in the possibilities of moral judgment and argument are necessarily associated with intolerance and absolutism, although that is surely a risk. Constitutional skeptics believe that the risks on the other side are more serious. The American Constitution has encouraged intolerance of views that cannot easily be reconciled with a very old text. In a world where we did not have a constitution to hold us together, we would be obliged to develop habits of tolerance, compromise, and critical introspection that are necessary to live with others of different views.

Ultimately, perhaps counterintuitively, constitutional skepticism rests on an optimistic view of human freedom and sociability. Skeptics claim that we do not need the authoritarian commands of outsiders to know right from wrong or live in peace with each other. Instead, we have the capacity and duty to make our own judgments in a way that is loyal to our deepest commitments while also respecting our fellow citizens and maintaining political community.

It is easy to see how someone might view these ideas as naïve, foolish, dangerous, or even incoherent. It is much harder to claim that they are un-American or have played no role in our history and tradition. On the contrary, for better or worse, they are central to (one version of) who we are.

\section{Evaluating Constitutional Skepticism}

What are we to make of this skeptical argument? The purpose of this article is to lay the groundwork that would make possible a debate about constitutional skepticism, not to actually conduct that debate. For that reason, and because I have laid out my views in detail elsewhere, ${ }^{485}$ this Part is

485 See Louis Michael Seidman, On Constitutional Disobedience (2013); Louis Michael Seidman, Political and Constitutional Obligation, 93 B.U. L. REv. 1257 (2013); Louis Michael Seidman, Why Jeremy Waldron Really Agrees with Me, HARV. L. REV. FORUM (2014). 
very brief. Nonetheless, it is possible to suggest few tentative conclusions that might be helpful in structuring the debate.

The history I recount above puts the lie to the argument that for better or worse, the American Constitution is essential to legitimate and stable government in the United States or that without it, civil liberties would disappear. Constitutional skeptics have been around as long as we have had a Constitution. The Constitution has regularly been denigrated, defied, and ignored. Yet we have not yet seen the collapse that many predict.

Of course, there are also important episodes in our history where civil liberties, at least arguably protected by the Constitution, have been violated. There is good reason to celebrate constitutional departures by Jefferson, Lincoln, and Franklin Roosevelt, but few people today admire Richard Nixon's abuse of executive power during the Watergate episode, the incarceration of opponents of World War I, McCarthyism's assault on free speech rights, or, indeed, Roosevelt's internment of Japanese Americans. The George W. Bush administration's assertions of untrammeled executive authority to intercept phone calls between Americans and indefinitely incarcerate enemy combatants with no access to judicial review are still a recent memory.

Opponents of each of these programs and actions marshaled constitutional arguments against them. It must be remembered, however, that advocates for the actions and programs had constitutional arguments of their own, some of which were endorsed by the Supreme Court. ${ }^{486}$ The important question is whether the country was well served by having these advocates and their critics debate the issues in terms of constitutional obligation.

There is little evidence that the bare assertion that, say, the prosecution of World War I dissenters violated constitutional language was effective in convincing people who otherwise favored these prosecutions that they were wrong. Rather than changing position, advocates of the prosecutions

$486 \quad$ See, e.g., Korematsu v. United States, 323 U.S. 214 (1944); Dennis v. United States, 341 U.S. 494 (1951); Debs v. United States, 24j9 U.S. 211 (1919). 
simply advanced constitutional interpretations of their own - interpretations that, as it happened, were endorsed by the Supreme Court. ${ }^{487}$ When the country was eventually convinced that it had made a mistake, the explanation was almost surely the waning of emergency conditions, rather than constitutional argument. To the extent that argument mattered at all, the argument that worked was not about mere constitutional obligation, but about the importance of free speech, dissent, open debate, and tolerance. These virtues are crucial, whether or not the Constitution commands them. In any event, whatever the historical record shows, there is good reason to believe that main danger that we face today comes from constitution worship rather than constitutional skepticism. The danger takes two contradictory forms. First, just because people regularly translate their ordinary political disagreements into constitutional rhetoric, constitution worship inflames political discourse. People who have different views about, say, national healthcare or federal power are not just wrong. They are traitors who reject the very idea of America as embodied in its sacred constitution.

The second source of danger comes from the opposite direction. As discussed above, ${ }^{488}$ the use of hyperbolic constitutional rhetoric coexists with widespread cynicism about the politicization of constitutional discourse. Even while they accuse their enemies of violating the constitutional compact, many Americans also understand that constitutional law is regularly used for partisan political purposes. Why else would the news media regularly identify Justices and lower court judges with reference to the President who appointed them, and why else would nomination hearings turn into pitched political battle? ${ }^{489}$

So constitution worship gives us the worst of both worlds. On the one hand, it inflames political rhetoric. On the other, it leads to disillusionment about the very possibility of transcending immediate political struggle. 
This is not to say that constitutionalism always and necessarily plays these roles. In certain times and places, constitutions can be a goad to political reform, a rallying cry for the dispossessed, a means of forging a nation out of disparate groups. We need to make contextual judgments about the value of constitutionalism and of the skeptical arguments that oppose constitutionalism. ${ }^{490}$

Nor is it to say that a change in attitude toward the Constitution would solve all of our political dysfunction. There are many reasons why our politics has become polarized and gridlocked. Still, there is reason to think that we would benefit from a revival of constitutional skepticism. The skeptical tradition insists that we come to grips with our political disagreements without trying to shut down opposing argument with what amounts to an authoritarian insistence that one is obligated to act in a certain way whether or not one agrees just because someone else has so commanded. It emphasizes the fact that it is for us, the living, to decide what kind of country we want, that it is deeply wrong to deny our own freedom to make these decisions, and that we cannot look to others long dead to solve our problems. This freedom in turn gives rise to an obligation to understand and compromise with our political adversaries. Constitutional skepticism, taken seriously, has the potential to energize our politics while helping us to respect our opponents.

\section{Conclusion}

The most powerful argument for constitutionalism rests on the need all political entities have to tell a coherent story about themselves over time. Thus, the United States is not just a collection of people who happen to inhabit the same physical space. We are a nation - a People -- and not just a random collection of people. To be a People, we need a common history and, it is said, the Constitution is at the center of our history.

There is, of course, some truth to this story, but the key to the skeptical argument is the recognition that there are other stories as well. Suppose we grant that a People needs a common

$490 \quad$ I have set out this argument at length in Louis Michael Seidman, Acontextual Judicial Review, , 32 Card. L. Rev. 1143 (2011). 
history extending over time. This history is not just something that exists. It is constructed and reconstructed through political struggle. There is a version of our history that emphasizes constitutional obedience, but there is also a version, more than adequately supported by actual historical events, that emphasizes continual struggle against constitutional authority. We have a choice as to which version to embrace.

I have said that this realization is a prelude to discussion, rather than discussion itself. Still, it is also true that once one understands that there really is a choice, in some sense the choice has already been made. The argument for constitutional obedience ultimately rests on a perception of powerlessness. The Constitution is just there; we are stuck with it, whether we like it or not, because it is part of the history that defines who we are. Once one sees that we in fact have power to define for ourselves who we are, this argument collapses.

All that remains, then, is to summon the courage to use the power that we have always already had. 